\title{
The ESAF at Ten Years Economic Adjustment and Reform in Low-Income Countries
}

Staff of the International Monetary Fund
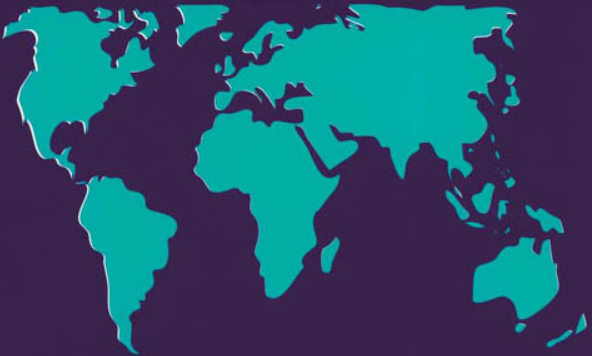


\section{The ESAF at Ten Years Economic Adjustment and Reform in Low-Income Countries}

Staff of the International Monetary Fund 
(C) 1997 International Monetary Fund

\section{Cataloging-in-Publication Data}

The ESAF at ten years : economic adjustment and reform in low-income countries / staff of the International Monetary Fund - Washington DC : International Monetary Fund, 1997.

p. $\quad \mathrm{cm}$. - (Occasional paper, ISSN $0251-6365 ; 156$ )

ISBN 1-55775-693-7

1. Structural adjustment (Economic policy) - Developing countries. 2. International Monetary Fund. 3. Economic assistance - Developing countries. I. International Monetary Fund. II. Occasional paper (International Monetary Fund); no. 156.

HC59.7.E83 1997

Price: US $\$ 18.00$

(US\$15.00 to full-time faculty members and students at universities and colleges)

Please send orders to: International Monetary Fund, Publication Services 70019 th Street, N.W., Washington, D.C. 20431, U.S.A.

Tel.: (202) 623-7430 Telefax: (202) 623-7201

E-mail: publications@imf.org

Internet: http://www.imf.org

\section{8}

recycled paper 


\section{Contents}

Preface

vii

I Overview 1

II Initial Conditions and the Setting for Adjustment $\quad 4$

\begin{tabular}{ll} 
Initial Conditions & 4 \\
\hline
\end{tabular}

The Adjustment Strategy

The Setting for Adjustment

I

\begin{tabular}{lr} 
III What Has Been Achieved? & $\mathbf{8}$ \\
\hline Macroeconomic Stabilization & 8 \\
\hline Fiscal Consolidation & 8 \\
\hline Inflation Control & 12 \\
\hline Structural Reform & 14 \\
\hline Openness & 20 \\
\hline Economic Growth & 23 \\
\hline External Viability & 27 \\
\hline
\end{tabular}

IV Lessons for Program Design 33

Growth-Enhancing Fiscal Adjustment 33

\begin{tabular}{lc} 
The Tax Burden & 34 \\
\hline Capital Spending & 34 \\
\hline Social Spending & 34 \\
\hline Other Current Spending & 35 \\
\hline Expenditure Management & 35 \\
\hline More Decisive Disinflation & 35 \\
\hline Potential Costs of Disinflation & 36 \\
\hline Implications for Program Design & 36 \\
Advancing Structural Reforms & 39 \\
\hline Public Enterprise Reform & 40 \\
\hline Restructuring Banking Systems & 41 \\
Sustaining Programs & 42 \\
\hline
\end{tabular}




\section{Boxes}

\section{Section}

I 1. The Enhanced Stuctural Adjustment Facility 1

III 3. Adjustment in ESAF-Supported Transition Economies 9

\begin{tabular}{ll} 
4. Indices of Structural Reform & 18 \\
\hline
\end{tabular}

\begin{tabular}{ll}
\hline 5. Defining Progress Toward External Viability & 29 \\
\hline 6.
\end{tabular}

IV 6. Strengthening Tax Systems 34

Tables

$\underline{\text { Section }}$

II 1. Economic and Social Indicators in ESAF and Other Developing Countries

III 2. Progress on Inflation Since the Pre-SAF/ESAF Period 15

3. Per Capita GDP Growth in 1991-95: Differentials Relative to Non-ESAF Developing Countries

\begin{tabular}{ll} 
4. External Debt: Some Long-Run Comparisons & 26 \\
\hline
\end{tabular}

\begin{tabular}{ll}
\hline 5. Net External Flows to ESAF Countries & 28 \\
\hline
\end{tabular}

6. Indicators of Progress Toward External Viability 31

IV 7. Deviations from Inflation Targets, by Net Domestic Assets Performance $\quad 38$

8. Financial Policies and Inflation Performance, 1993-95 39

\section{Figures}

\section{Section}

II 1. The External Environment 6

III 2. Fiscal Trends in ESAF Countries 10

3. Fiscal Adjustment in SAF/ESAF-Supported Programs: Averages by Region

4. Fiscal Adjustment in SAF/ESAF-Supported Programs: By Initial Conditions

5. Composition of Government Spending

6. Inflation Trends by Region 13

7. Inflation Targets, by Degree of Initial Inflation 14

8. Inflation Targets and Outturns 14

9. Status of Structural Reform in ESAF Countries 16

10. The Pace of Structural Reform 17

11. Share of Trade in GDP and Exchange Rates 21

12. Trends in External Trade 22

\begin{tabular}{ll}
13. & Real Per Capita GDP Growth \\
\hline
\end{tabular}

14. Growth, Saving, and Investment 23

15. Social Indicators of Development 24

16. Explaining Increases in Growth Since the Early 1980s 25

17. Balance of Payments Developments 26

18. Alternative Measures of the Debt-Service Burden 30

19. Growth of Export Volume and of Real GDP, and Change in Fiscal Balance During the SAF/ESAF Period 
IV 20. Association of Real Per Capita GDP Growth with Log Inflation 36

21. Real Per Capita GDP Growth in SAF/ESAF Programs 37

22. Inflation Performance With and Without Anchors 39

23. Frequency Distribution of Changes in the Fiscal Balance 43

24. Targeted Change in Fiscal Balance in Interruptions Affected by Policy Slippages

The following symbols have been used throughout this paper:

... to indicate that data are not available;

- to indicate that the figure is zero or less than half the final digit shown, or that the item does not exist;

- between years or months (e.g., 1994-95 or January-June) to indicate the years or months covered, including the beginning and ending years or months;

I between years (e.g., 1994/95) to indicate a crop or fiscal (financial) year.

"Billion" means a thousand million.

Minor discrepancies between constituent figures and totals are due to rounding.

The term "country," as used in this paper, does not in all cases refer to a territorial entity that is a state as understood by international law and practice; the term also covers some territorial entities that are not states, but for which statistical data are maintained and provided internationally on a separate and independent basis. 
This page intentionally left blank 


\section{Preface}

Since 1986, the IMF has been supporting the adjustment and reform programs of its low-income member countries with financial resources on highly concessional terms through the Structural Adjustment Facility (SAF) and Enhanced Structural Adjustment Facility (ESAF). As their names suggest, these facilities were intended to back fundamental reform in the structure and institutions of the economies concerned, as well as strong macroeconomic policies, with the objectives of promoting higher economic growth and external viability in a balanced manner.

This paper is a summary of the latest periodic review of experience under SAFand ESAF-supported programs (the last comparable study was published in 1993). It provides an overview of policies and economic developments in 36 countries during 1986-95, pulls together the main lessons from this experience, and sets out proposals for strengthening the design and implementation of future programs. The report draws on a number of background studies, which will also be published shortly. The review was directed by Susan Schadler, Senior Adviser in the Policy Development and Review Department, under the general guidance of the department's Director, Jack Boorman. The principal author of the summary report was Hugh Bredenkamp, Chief of the Policy Review Division. The staff team comprised Sharmini Coorey, Jorg Decressin, Louis Dicks-Mireaux, Zia Ebrahim-zadeh, Ali Ibrahim, Kalpana Kochhar, Jean Le Dem, Mauro Mecagni, Steven Phillips, and Tsidi Tsikata. A background study on revenue and expenditure policies in SAF- and ESAF-supported programs was prepared by staff of the Fiscal Affairs Department, under the direction of George Abed, Senior Adviser.

The authors are grateful to numerous colleagues in the Fund for detailed comments on the paper; to Kirsten Fitchett, Emmanuel Hife, and Kadima Kalonji for research assistance; to Lourdes Alvero, Julia Baca, and Olivia Carolin for secretarial assistance; and to Esha Ray of the External Relations Department for editorial assistance.

The opinions expressed in the paper are those of the authors and do not necessarily reflect the views of the IMF or of its Executive Directors. 
This page intentionally left blank 


\section{Overview}

F or over 10 years, the IMF has supported adjustment and reform programs in many of its low-income members through two facilities established specifically for that purpose-the Enhanced Structural Adjustment Facility (ESAF) and its precursor the Structural Adjustment Facility (SAF) (see Box 1). By the end of 1994, 36 countries had availed themselves of these facilities, in support of 68 multiyear programs (see Appendix). ${ }^{1}$ This study summarizes the findings of a review of the experience under these programs and of economic developments in the countries that undertook them. Drawing on a number of detailed studies, ${ }^{2}$ it surveys the policies that have been implemented with SAF/ESAF support, assesses economic developments, and identifies possible modifications to the focus and design of ESAF-supported programs that could strengthen economic performance. Although the study is naturally concerned with the IMF's activities, all the countries under review also received policy advice, technical assistance, and financial support for their programs from the World Bank and other agencies and donors in the international community.

The last review of this kind covered the experience of 19 countries through mid-1992. ${ }^{3}$ It concluded that the experience under SAF/ESAF-supported programs had been generally favorable. Macroeconomic policies had been strengthened, and significant structural reforms undertaken. Together with sharply increased net resource transfers to the countries concerned and other exogenous developments, these policy advances had contributed to improvements in most indicators of economic performance: growth in output and export volumes, in particular, had strengthened, and inflation had fallen. The record had been uneven, however. Not all poli-

\footnotetext{
IThis review covers only countries that began ESAF-supported programs before December 31, 1994, on the grounds that the experience of those starting later than this date would be too recent to evaluate fairly. All SAF and ESAF multiyear arrangements approved before December 31, 1994, are covered.

${ }^{2}$ Bredenkamp and Schadler (forthcoming) and Abed and others (forthcoming).

${ }^{3}$ Schadler and others (1993).
}

\section{Box I. The Enhanced Structural Adjustment Facility}

In the mid-1980s, the IMF recognized that its low-income member countries needed access to highly concessional financial resources to support medium-term structural adjustment programs. It therefore set up the Structural Adjustment Facility (SAF) in 1986, and the Enhanced Structural Adjustment Facility (ESAF) one year later. In 1994, the ESAF was extended and enlarged, and in 1996 the basis for the continuation of ESAF operations in the twenty-first century was agreed upon. Commitments of assistance from the SAF ceased in 1993. ESAF arrangements are intended to support especially vigorous adjustment programs with a higher level of financial assistance than was available under the SAF. Loan commitments are made for a three-year period, in support of three successive annual programs. They carry an annual interest rate of 0.5 percent and repayments are made semiannually, beginning $51 / 2$ years and ending 10 years after disbursement. Seventy-nine IMF member countries are currently eligible for ESAF assistance.

cies had been implemented as envisaged, and a difficult world economic climate and deteriorating terms of trade had adversely affected outcomes in key respects. As many as half of the countries reviewed had failed to make discernible progress toward external viability, although almost all had halted the deterioration in their debt situations. Relatively little had been achieved in the reform of banking systems and, especially, of public enterprises. On the basis of that review, it was concluded that:

- The objectives and design of programs supported by concessional ESAF resources were appropriate; the importance of a medium-term perspective for adjustment was reconfirmed, as was the emphasis on structural reform and institution building to support strong macroeconomic policies.

- More ambitious fiscal adjustment was required to reduce excessive deficits and to sustain the 
improvements in competitiveness that had been achieved. This extra adjustment should come through fundamental reforms of expenditure control and tax systems.

- A more forceful effort was needed-in close collaboration with the World Bank-to address the lagging reforms of public enterprises and to press ahead with bank restructuring, improvements in bank supervision, and the transition to indirect instruments of monetary control.

- The increased emphasis on social issues was welcome. It was important to protect the more vulnerable social groups from the impact of adjustment policies and, to this end, the IMF should work closely with the World Bank on the design of social safety nets.

- The excessive debt burdens still facing many low-income countries warranted further action by the international community, including through the flexible implementation (and possibly further enhancement) of Paris Club concessions for low-income countries that maintained sound policies. ${ }^{4}$

The present study begins with a brief description of the conditions prevailing prior to SAF/ESAF-supported programs. In Section II, it recalls the main elements of the implied strategy for adjustment and reform and comments on the economic and political environment within which programs had to be implemented. Section III reviews the record with regard to policies - fiscal consolidation and restructuring, inflation control, and structural reform - and the resulting trends in economic growth and countries' external positions. The study concludes that most countries pursuing reform and adjustment programs with the support of the SAF and ESAF have strengthened their economies materially over the past 10 years. Fiscal imbalances have been reduced, and macroeconomic policies have eradicated almost all instances of high inflation. Many improvements in economic structure that the facilities were intended to promote appear to have taken root, and to be spreading, as the pace of structural reform has accelerated in recent years. In most of the countries under review, these policy gains appear to have helped to improve growth and living standards and to bring about a strengthening of external positions. Nevertheless, progress in a number of areas-macroeconomic and structural-has fallen short of program objectives and, most important, of what is needed for countries to reach their growth potential. Progress in

\footnotetext{
${ }^{4}$ Such action was taken-first, with the introduction by the Paris Club of highly concessional terms in December 1994 (the so-called Naples terms), and subsequently by agreement on the debt initiative for the heavily indebted poor countries sponsored by the World Bank and the IMF.
}

reducing intermediate inflation rates, creating more outward-oriented economic conditions, and moving toward external viability has also been uneven.

In light of these findings, the final section of the study draws lessons from the ESAF countries' experience and identifies various possible ways in which ESAF-supported programs might be reoriented, and in some respects redesigned, to achieve the two key objectives of the ESAF-sustained higher growth, with an improvement in living standards, and progress toward external viability. ${ }^{5}$ These two goals are found to be mutually reinforcing and achievable through a common set of policies. Several aspects of ESAF-supported programs are considered: the need for further and more growth-enhancing fiscal adjustment that would also improve prospects for viability; the case for more decisive disinflation as a spur to growth and measures to achieve it; steps to advance structural reforms in two areas where performance has continued to lag-the public enterprises and banking systems; and, finally, modifications to promote more continuity in policy implementation.

The aim in most of this analysis is to step back from the program-by-program detail and look rather at how far countries progressed between the beginning of their SAF/ESAF-supported adjustment (which, by and large, means since the mid-1980s) and 1995, the most recent year for which comprehensive data exist. This choice reflects, first, the view that adjustment and reform are a continuing process, and do not begin or end with specific programs; second, that the full effects of policies may emerge only gradually, and with an uncertain lag; and, third, that there is now a sufficient span of experience with adjustment in the countries under review to allow a more extended perspective than was possible at the time of the last ESAF review. The present study deploys a variety of before-and-after, cross-country (see Box 2), and control-group comparisons to examine the links between policies implemented and outcomes achieved.

There has been much controversy over the appropriate approach to evaluating IMF- (and World Bank-) supported programs. Some evaluations have focused on the question of whether economies grew more rapidly (or had more favorable outcomes for other key variables) as a result of their choice to enter into an IMF arrangement. ${ }^{6}$ This study does not attempt to establish the extent to which policies or outcomes were "caused" by SAF/ESAF support and conditions. Rather it assumes that the basic strategy

\footnotetext{
5In this study, the terms "ESAF countries" and "ESAF users" are used interchangeably to refer (solely) to the countries under review.

${ }^{6}$ Bredenkamp (forthcoming) discusses these methodological issues and refers to some key papers on the subject.
} 


\section{Box 2. The Countries Under Review}

For the purposes of exposition and analysis, it has proven useful in this study to divide the 36 countries under review into five regional groupings, as follows:

\begin{tabular}{lllcl}
\hline CFA Africa & Other Africa & \multicolumn{1}{c}{ Asia } & Western Hemisphere & Transition Economies \\
\hline Benin & Burundi & Bangladesh & Bolivia & Albania \\
Burkina Faso & The Gambia & Nepal & Guyana & Cambodia \\
Côte d'Ivoire & Ghana & Pakistan & Honduras & Kyrgyz Republic \\
Equatorial Guinea & Guinea & Sri Lanka & Nicaragua & Lao People's \\
Mali & Kenya & & & Democratic Republic \\
Niger & Lesotho & & Mongolia \\
Senegal & Madagascar & & Vietnam \\
Togo & Malawi & & \\
& Mauritania & & \\
& Mozambique & & \\
& Sierra Leone & & \\
& Tanzania & & \\
& Uganda & & \\
& Zimbabwe & & \\
& & & \\
\end{tabular}

In many contexts, these groupings were found to represent quite well the trends or specific characteristics in the constituent countries, while bringing out interesting or important differences between the groups. There were numerous instances, however, where substantial diversity - or some notable outliers - were evident within the groups, and the report comments on these cases where they occur. In general, considerable care has been taken-including through comparisons of means and medians, and using formal significance tests where relevant-to avoid drawing spurious inferences from group averages.

for growth and adjustment underlying the ESAFwhich is based on a large body of analytical and empirical literature that draws on the experience of all developing countries-is the right one, and concentrates on assessing how well that strategy was reflected in the design and execution of programs. The study also seeks evidence on how much progress has been made in strengthening economic performance in ESAF countries and how the basic strategy can be refined and improved.
This review of SAF/ESAF-supported programs conducted by IMF staff will be complemented by an independent evaluation currently being undertaken by a panel of outside experts. The external evaluators will use a case-study approach to examine three topics in detail: (1) developments in countries' external positions; (2) social policies and the composition of government spending; and (3) the determinants and influence of differing degrees of national ownership of ESAF-supported programs. 


\section{Initial Conditions and the Setting for Adjustment}

B efore turning to the record of adjustment and reform undertaken in ESAF countries, it is useful to recall why countries embarked on this process, and what they hoped to achieve. This section looks first, in broad terms, at the nature of the economic difficulties that countries faced prior to their first SAF/ESAF-supported program, since these naturally determined much of what followed. The objectives and key components of the strategies designed to address those problems are then summarized. The final element considered is the background-both domestic and global-against which policies were implemented.

\section{Initial Conditions}

Countries seeking support under the SAF and ESAF had typically accumulated deep-seated economic problems over an extended period. Most came to the IMF in circumstances not of sudden macroeconomic or financial instability but rather of persistently weak growth, often chronically high inflation, and fragile external positions. Development strategies, based commonly on pervasive state intervention in the economy, public ownership, and protectionism, had left a dismal legacy. Distortions and rigidities were stifling entrepreneurship and promoting waste and corruption. They also aggravated the vulnerability of economies that were unusually prone to adverse economic shocks. In many countries, especially in Africa, these profound weaknesses had been masked during much of the 1970s by heavy foreign borrowing on the back of improving terms of trade. When commodity prices turned down sharply and interest rates rose in the early 1980 s, both the debts and the policies they had financed became manifestly unsustainable. ${ }^{7}$

\footnotetext{
${ }^{7}$ See Schadler and others (1993) for a fuller description of the state of countries' economies prior to embarking on SAF/ESAFsupported adjustment programs.
}

The immediate need in most cases was to bring some order to countries' external cash flow positions, through a combination of debt relief or rescheduling and new resource flows. Even though many countries had already begun to adjust in the context of programs supported by stand-by arrangements, their external situations prior to SAF/ESAF-supported programs remained precarious: current account deficits (excluding official transfers) averaged 12-14 percent of GDP, scheduled debt service was typically $35-40$ percent of exports, and official reserves were uncomfortably low, given the volatility of these countries' foreign exchange earnings. External imbalances were particularly severe among future ESAF users in Central America and parts of Africa, much less so in Asia.

Net resource transfers did pick up sharply in the context of SAF/ESAF-supported programs. By this time, however, it was widely recognized that the debt crisis of the early 1980 s was not a temporary problem of liquidity shortage - a matter of tiding over until the next upturn in commodity prices - but a true watershed. Countries had become locked in a cycle of low saving, weak external positions, and low growth, with each element constraining the others. In the years leading up to their first SAF/ESAF arrangement (by and large, the early to mid-1980s), most were experiencing stagnant exports and declining living standards, with saving rates averaging only about 8 percent of GDP.

Certainly, the early 1980 s were lean years for the developing world as a whole. But future SAF/ESAF users were on average falling further behind other developing countries in terms of per capita income during this period (Table 1): their saving rates were half the average of other developing countries, and they had larger budget deficits, higher inflation, higher levels of external debt, more distorted exchange systems, faster population growth, and more adverse social indicators (such as education, health, and life expectancy). It was apparent that fundamental economic reform was required to reverse these trends and deliver a lasting improvement in growth and the external finances. 
Table I. Economic and Social Indicators in ESAF and Other Developing Countries (In percent a year, unless otherwise indicated)

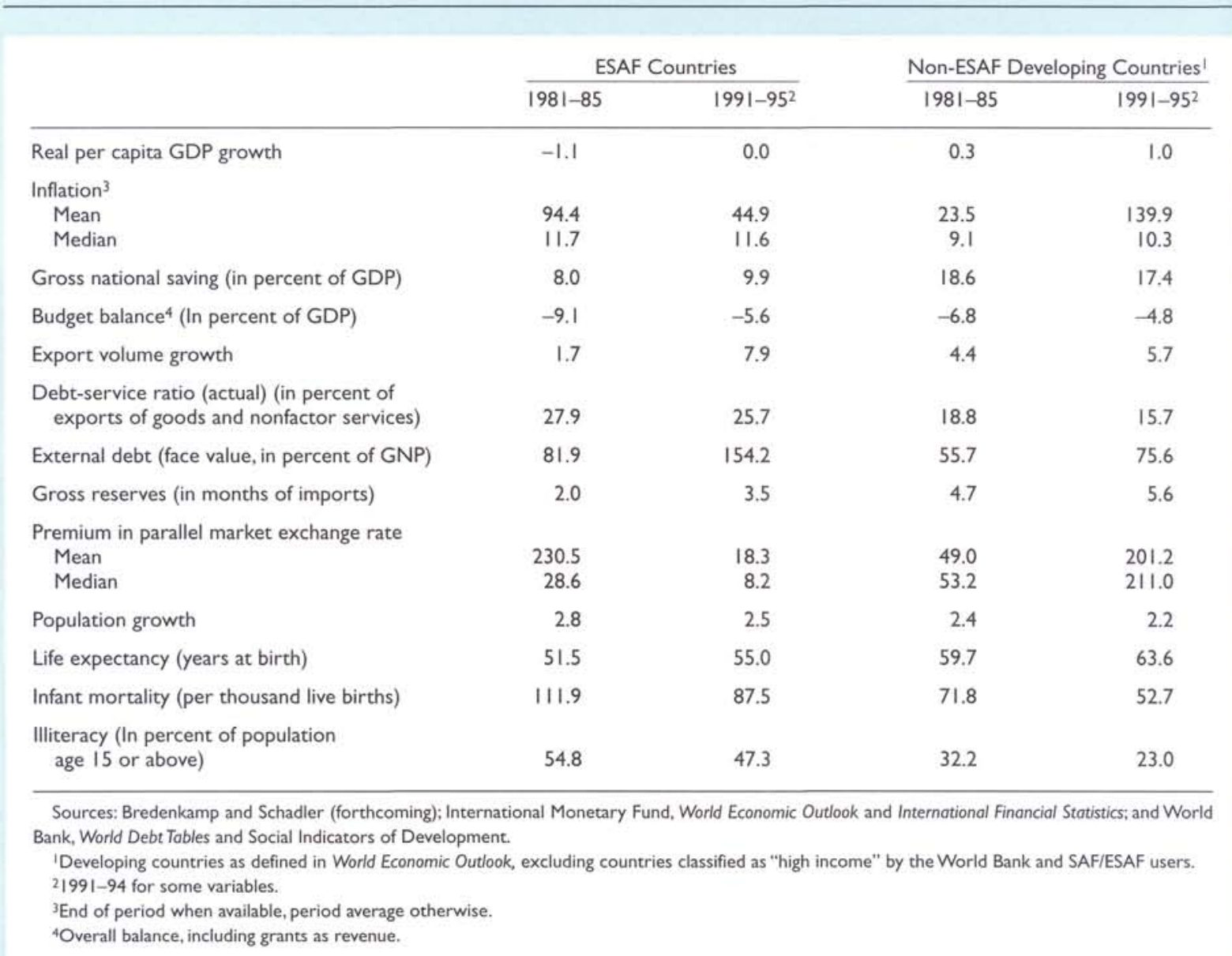

\section{The Adjustment Strategy}

SAF/ESAF-supported adjustment programs varied widely in their emphasis and detail, in keeping with the differing circumstances of individual countries. But countries' common problems-and the universal underlying aim of achieving higher sustainable economic growth-resulted in reform strategies that shared certain core objectives.

First, to raise saving rates. The very low saving rates in ESAF countries were reflected in a combination of low investment ratios and high current account deficits. Since public dissaving was seen both as a root of this problem and as the most likely source of an early improvement in national saving rates, fiscal adjustment was at the heart of almost all SAF/ESAF-supported programs. Supporting policies, to bolster private saving, included financial sector reform and a shift from negative to positive real interest rates. The basic aim was to shift the macroeconomic balances underlying current account deficits in favor of greater investment.

Second, to secure macroeconomic stability. Although only 9 of the 67 three-year SAF/ESAF arrangements covered by this review began with initial inflation rates in excess of 40 percent, most ESAF countries - with the exception of those in the CFA franc zone and some in Asia-had experienced volatile inflation for some years, with rates seldom falling into the single-digit range. This instability was viewed as disruptive, and a deterrent to investment. Programs aimed to reduce it by bringing inflation to low (single-digit) levels and by putting the government budget (a chronic source of financial instability) on a surer footing. Low inflation was also considered an important factor in improving conditions for the poorest sectors of the population. 
Figure I. The External Environment
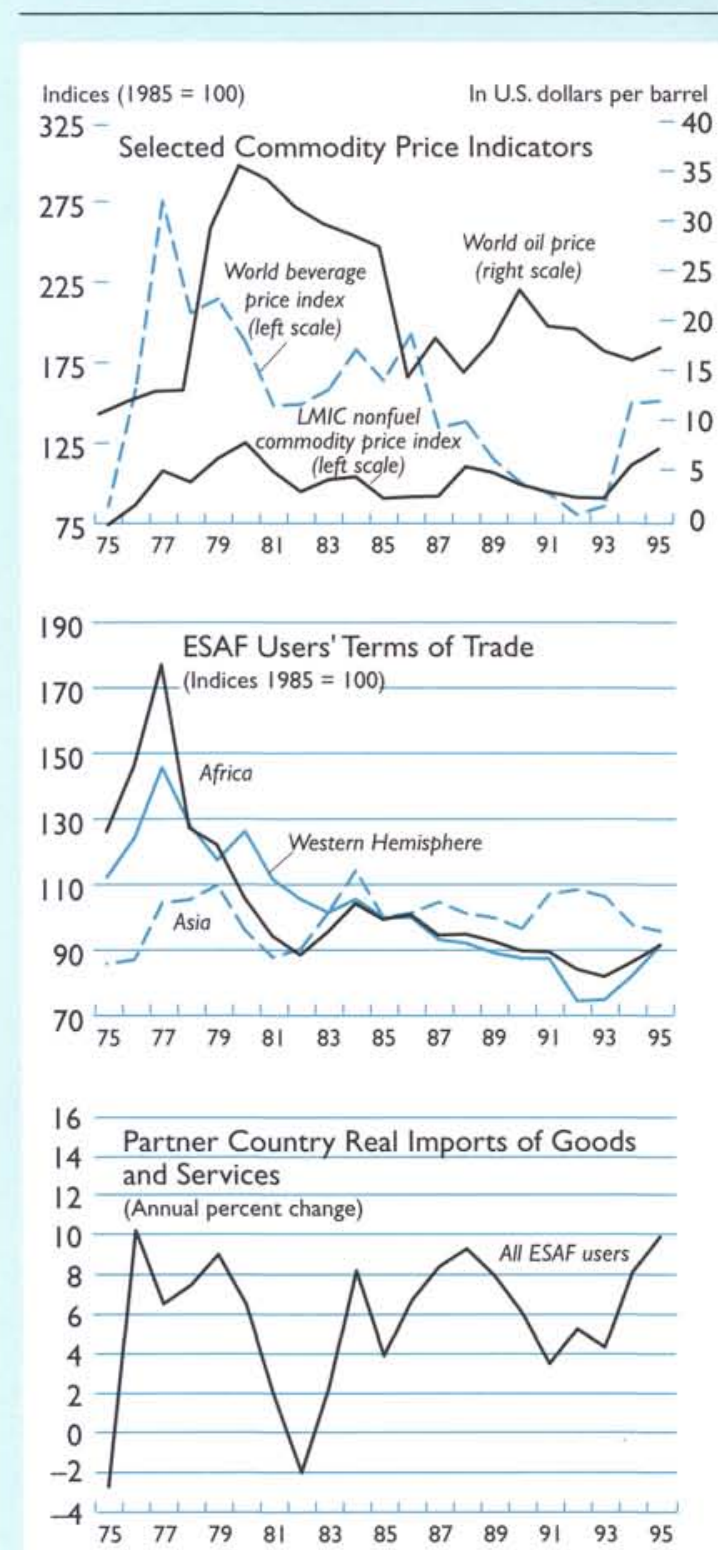

Sources: International Monetary Fund, International Financial Stotistics and World Economic Outlook; and IMF staff estimates.

Third, to liberalize and open economies to foreign trade. ESAF economies were generally inward-oriented with distorted internal relative prices. Producers faced substantial protection from external competition and disincentives against export activity. Programs sought to eliminate systemic antiexport bias through removal of exchange and trade restrictions (particularly quantitative import restric- tions), exchange rate unification, tariff reform, liberalization of export price and marketing regimes, and public enterprise reform. In addition, in many cases, real devaluations of the domestic currencysecured by fiscal adjustment-aimed at enhancing the outward orientation of the economy.

Fourth, to reduce government intervention and promote well-functioning markets. The state needed to cease controlling prices, foreign exchange, and product marketing and by and large to withdraw from ownership and control of the means of production. Instead, its challenge was to establish a legal and institutional framework conducive to private business, where contracts could be enforced and property protected. The development of the financial sector was encouraged through a combination of financial and operational restructuring, privatization, and more effective supervision. Deregulation of pricing and marketing, public enterprise and banking system reform, and privatization were thus important structural components of SAF/ESAFsupported programs. The sequencing of reforms in these areas posed particularly difficult issues.

Fifth, to reorient government spending and restructure revenues. "Government," if represented by the share of its expenditure in GDP, was not unusually large in ESAF countries, but it was doing many of the wrong things. An excessive portion of government spending was devoted to subsidies for consumers and state-owned firms, wages for inefficient (or, in some cases, nonexistent) civil servants, ill-chosen capital projects, and the military. Programs aimed increasingly to reorient spending from areas with relatively low social and economic rates of return-unproductive spending - to activities with high rates of return, such as primary education and basic health care. Revenue systems to finance these expenditures also needed to be rendered more efficient, through the simplification of tax and tariff structures, a move toward modern tax instruments such as the value-added tax (VAT), and more effective tax and customs administration.

Sixth, to mobilize external resources. A key part of the strategy under the ESAF was to support countries' reform efforts by temporarily easing the external financing constraint and to move them toward viability in part through reducing reliance on debtcreating inflows and, in some cases, debt burdens. Policies to this end included the clearance of payments arrears, agreements on debt reschedulings and debt relief, a shift to more concessional financing, and a rebuilding of official reserves.

\section{The Setting for Adjustment}

Reforms of this scope and magnitude would be challenging in the best of circumstances, and the en- 
vironment within which policymakers had to implement ESAF-supported programs often complicated their task.

During the late 1980s and early 1990s, most countries had to contend with a sizable deterioration in their terms of trade as they embarked on their first SAF/ESAF-supported programs. The many countries for which tea, coffee, or cocoa was the principal export-almost one-third of all ESAF users-suffered from a 60 percent drop in world beverage prices between 1986 and 1992 (Figure 1). Other nonfuel commodity prices - and, more generally, the growth of demand in ESAF users' export marketsweakened from 1988 through the industrial country recession of 1991-93.

Roughly one in four ESAF users also experienced severe civil strife or war during the late 1980s and early 1990 s, in some cases associated with transition to more pluralistic political systems. In such circumstances, it was difficult to formulate policies, still less to sustain their implementation, and this was a factor contributing to the interruption or breakdown of a number of programs. In addition, many countries suffered from natural disasters during this time, including recurrent drought in subSaharan Africa and cyclones and flooding in Bangladesh and Nepal.
On the whole, market conditions improved for ESAF users after 1993. Nonfuel commodity prices (especially beverage prices) and the growth of global demand picked up markedly during 1994-95. At the same time, world energy prices remained subdued, at levels $20-30$ percent below their peak in 1990. The prevalence of civil conflict also appeared to diminish in the mid-1990s, albeit with some striking exceptions (Burundi, Pakistan, Sierra Leone, and Sri Lanka). This generally more favorable climate seems to have continued in 1996, and is likely to have contributed to the widespread improvement in growth in ESAF countries during 1994-96.

ESAF countries suffered throughout the adjustment period, however, from restricted access to industrial country markets for key export productsparticularly in agriculture, textiles, and clothing. Various international agreements defining market access, and granting preferences in some cases, contributed to segmenting markets and discouraging export diversification. Whether trade barriers were eased or intensified over time for ESAF users is difficult to determine: some preferential trading schemes have been broadened, with liberalizing effects; by contrast, some ESAF countries were adversely affected by increased protection in textiles and agriculture. 


\section{What Has Been Achieved?}

rogress with regard to the strategy for adjustment and reform can be assessed both on the basis of policies implemented and outcomes achieved. The experience of SAF/ESAF-supported programs-and the countries that undertook them-is reviewed below from both perspectives. Fiscal policies, inflation, structural reforms, and the degree of openness are examined first, before turning to the outcomes for economic growth and countries' external positions. Because adjustment in the six transition economies under review began comparatively late (see Box 3 for a synopsis) and historical data are generally lacking for these countries, most of the analysis that follows relates to the nontransition countries.

\section{Macroeconomic Stabilization}

\section{Fiscal Consolidation}

In the broadest terms, fiscal adjustment in the ESAF countries appears to have proceeded in three phases since the beginning of the $1980 \mathrm{~s}$. The first phase, prior to the inception of the SAF in 1986, was marked by early attempts to tackle the most egregious fiscal imbalances - typically to be found in non-CFA Africa and the Western Hemisphere. These efforts, often made in the context of programs supported by standby arrangements with the IMF, met with some success (Figure 2). Progress slowed markedly, however, during much of the late 1980 s and early 1990s. Asian and Western Hemisphere countries continued to trim budget deficits over this period, but African countries saw their budget positions hold steady at best, with deteriorations in most CFA franc zone countries. Progress resumed only after 1994, as countries took advantage of an upturn in export demand, growth, and the terms of trade to trim budget deficits, mainly by containing expenditure as output increased. ${ }^{8}$

The average SAF/ESAF-supported program aimed, over a three-year horizon, to cut primary

\footnotetext{
${ }^{8}$ The CFA franc zone countries achieved significant savings in the government wage bill by containing nominal wage growth following their 1994 devaluation.
}

budget deficits (in relation to GDP, excluding grants and privatization receipts) by a little under half-or 3 percentage points of GDP. ${ }^{9}$ African countries sought greater-than-average adjustment, including in programs supporting the major devaluation of the CFA franc in 1994 (Figure 3). On average, the greatest adjustment was targeted in cases where initial imbalances were the most severe (Figure 4).

The relative reliance on targeted expenditure restraint and revenue increases to bring about this adjustment varied widely, depending to some degree on initial conditions. Thus, although programs envisaged cuts in noninterest expenditure relative to GDP of about 2 percentage points on average over three years, almost half targeted increased or unchanged spending from preprogram levels. The deepest cutsaveraging more than $2 \frac{1}{2}$ percentage points over three years - were sought in Africa, where initial spending levels were highest (the transition economies excepted). In all other regions, the principal source of fiscal adjustment was to be increased revenues. Across the regions (again, other than the transition economies) the aim was to raise revenue-GDP ratios by about 1 percentage point over three years. The constellation of revenue targets (see Figure 4) implied some degree of convergence in revenue-GDP ratios over time: programs aimed to maintain (or, in some cases, reduce) these ratios where the initial tax burden was relatively high, and boost them in countries where initial revenues were below average.

Looking more closely at the modalities of adjustment within spending and revenue totals, the diversity across countries increases still further, but a few important patterns can be discerned: ${ }^{10}$

\footnotetext{
${ }^{9}$ Unless otherwise specified, the observations in this section are based on a restricted sample of 28 (out of 36 ) countries and 47 (out of 68) SAF/ESAF-supported programs, because of the absence of three-year-ahead fiscal targets for some programs.

${ }^{10}$ These findings are taken from Abed and others (forthcoming), who examine revenue and expenditure policies in SAF/ESAF-supported programs in more detail, based on one-year-ahead or within-year targets. An analysis on three-year-ahead targets, to be consistent with the rest of this section, was not possible at this level of disaggregation, since medium-term program targets were either not set or not reported in the necessary detail. Three-year-ahead targets were generally more ambitious than nearer-term targets.
} 


\section{Box 3. Adjustment in ESAF-Supported Transition Economies}

The demise of central planning and the transition to a market-based economy began at different times for the six transition countries under review: in 1986 for the Lao People's Democratic Republic, 1989 for Vietnam, 1990 for Mongolia, and 1992 for Albania and the Kyrgyz Republic; Cambodia-still struggling with armed internal conflict-did not undertake comprehensive adjustment until 1993. ESAF-supported programs began in 1993 and 1994 in all but one of the six countries. The Lao People's Democratic Republic, the exception, began adjustment under a SAF arrangement in 1989, followed by an ESAF arrangement in 1993. ESAF-supported programs in these countries were, in many respects, a continuation and a deepening of adjustment efforts initiated at the beginning of transition. Although their strategies included the same core elements as in other ESAF countries (see section on "The Adjustment Strategy" above), adjustment programs in the transition economies tended to place greater emphasis on certain areas, consistent with their different circumstances.

- Rapid stabilization was a central objective, to be achieved mainly through strong fiscal adjustment and tight control of credit, particularly to public enterprises. Stabilization efforts were most successful in Albania and the Indochinese economies, all of which reduced inflation to low levels, initially through a credit-based approach backed in Indochina by wage controls. During 1992-95, following initial stabilization, Cambodia, the Lao People's Democratic Republic, and Vietnam maintained stable nominal exchange rates (with official rates generally within 1 percent of the parallel market rate) through tight fiscal and monetary policy. Although Mongolia and the Kyrgyz Republic also made notable progress in reducing inflation in 1994-95, their inflation rates remained relatively high ( 53 percent and 32 percent, respectively, at the end of 1995), mainly because of difficulties in curbing fiscal deficits and controlling credit growth to public enterprises.

- Strong fiscal adjustment, particularly through tax and public enterprise reform, was crucial. Budget deficits were reduced sharply in Albania, the Lao People's Democratic Republic, and Vietnam. In Albania, measures to improve tax and customs administration were delayed, and fiscal adjustment relied mainly on programmed reductions in current spending, facilitated by the decline in unemployment (reflecting greater private sector activity) and reforms in the budget process.
Government employment was reduced by close to a third from mid-1992 to February 1995, spending was shifted toward investment, direct subsidies were virtually eliminated by 1995 , and other current expenditures were scaled back considerably. Tax reforms were introduced early (1988-89) in the Lao People's Democratic Republic and Vietnam, and later in Cambodia. By 1994-95, revenues had strengthened considerably in all three countries, aided in Vietnam by the improved financial performance of state enterprises. Fiscal deficits were kept to moderate levels, initially by lowering the real wage bill (partly through retrenchment, with labor later being absorbed by the growing private sector), lowering subsidies and transfers to public enterprises, and reducing capital outlays and social services. The compression of capital and social spending was subsequently reversed as revenues were raised. Reform efforts failed to increase revenues in the Kyrgyz Republic and Mongolia, partly due to tax arrears and poor tax administration, and overall fiscal deficits were markedly higher.

- Wide-ranging structural reforms, particularly public enterprise reform and privatization, received strong emphasis. In Vietnam, state enterprises were given substantial management autonomy in 1988-89, while policies were adopted to increase competition (by liberalizing imports and encouraging foreign direct investment), harden budget constraints (by eliminating most direct subsidies and directed credit), and subject enterprises to uniform rules of taxation. As a result, the net budgetary contribution of enterprises rose to over 10 percent of GDP by 1994-95, partly through increased profits from the oil sector. Similar efforts were undertaken in the Lao People's Democratic Republic and Cambodia. Although a majority of small and medium-sized enterprises were privatized in Albania, the Kyrgyz Republic, and Mongolia by the end of 1995, ESAF-supported programs called for further restructuring and privatization of strategic enterprises. In all six countries, weak banking systems remain a concern. In addition, a need for further reforms in the legal and institutional framework was identified in programs, especially those governing land in Albania and the Kyrgyz Republic. By the end of 1995, all six countries had undertaken extensive liberalization of prices, trade, and foreign investment and had relatively few exchange restrictions on current transactions.
- First, most programs targeted a significant shift from current to capital spending: two-thirds of programs envisaged increased capital expenditure, while almost 60 percent planned cuts in current spending relative to GDP.

- Second, of the saving sought in current spending, roughly half was to come from the govern- ment wage bill and half from subsidies and transfers (through, for instance, reduced support for public enterprises and better targeting of consumer subsidies).

- Third, most programs in recent years included pledges to strengthen health and education spending, although this objective was seldom 
Figure 2. Fiscal Trends in ESAF Countries (Averages, in percent of GDP)
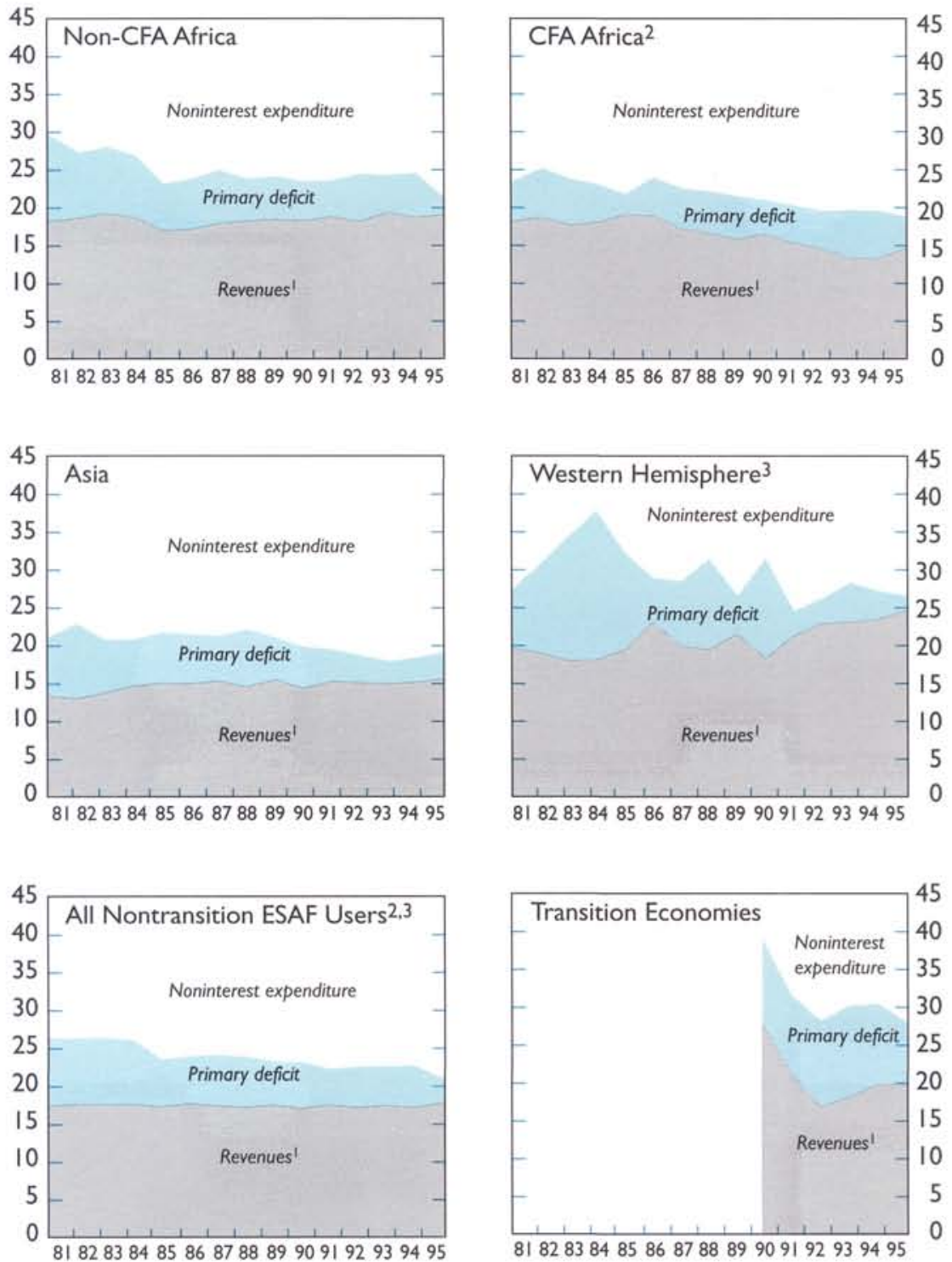

Source: IMF staff estimates.

'Excluding grants.

2Excluding Equatorial Guinea.

${ }^{3}$ Excluding Guyana.

quantified; they also commonly incorporated specific safety net measures for vulnerable groups to mitigate the short-term impact of price increases or reduced employment opportunities.
- Fourth, on the revenue side, programs typically aimed to shift the burden from nontax to tax revenues, from direct to indirect taxation (often through the introduction or expansion of a VAT), 
Figure 3. Fiscal Adjustment in SAF/ESAFSupported Programs: Averages by Region' (In percent of GDP)

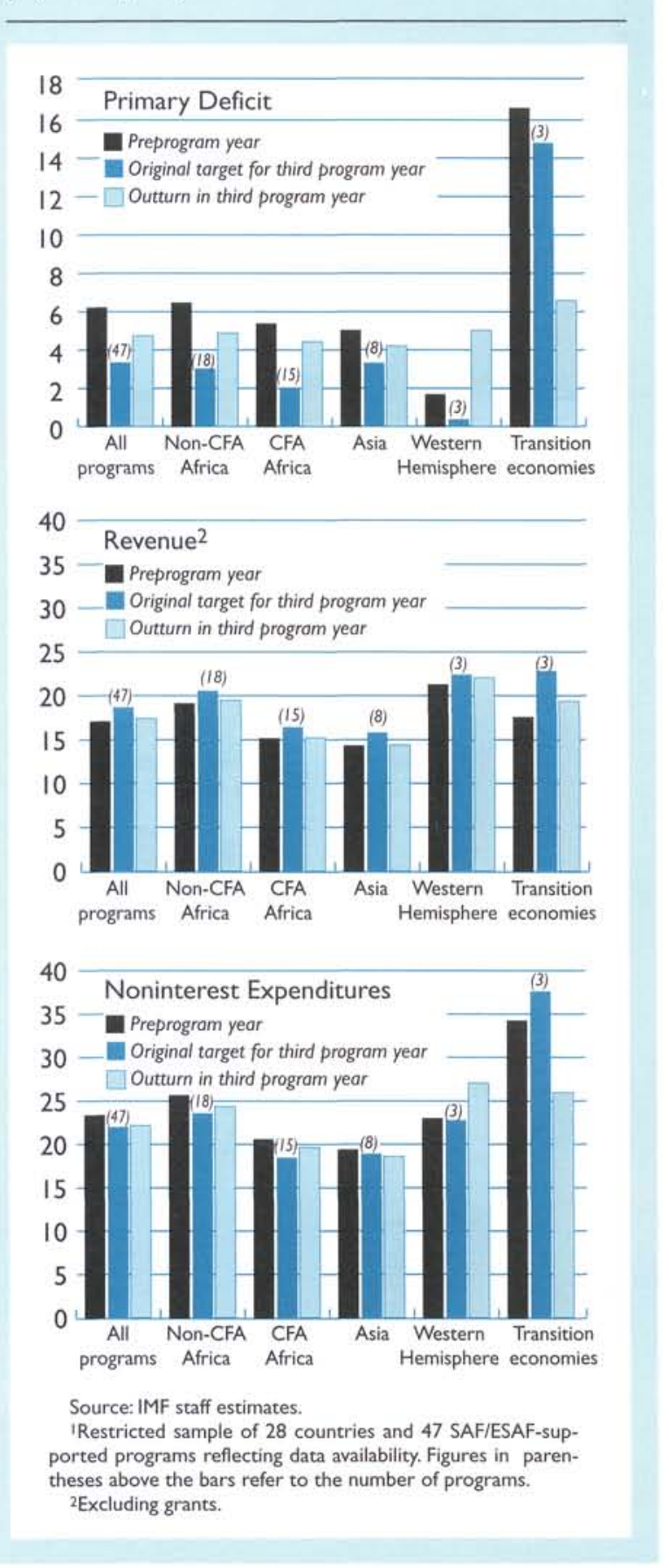

and to boost tax receipts from international trade; the latter was sought in some cases as a matter of expediency, but in others it was simply a product of expected increases in imports, im-
Figure 4. Fiscal Adjustment in SAF/ESAFSupported Programs: By Initial Conditions' (In percent of GDP)
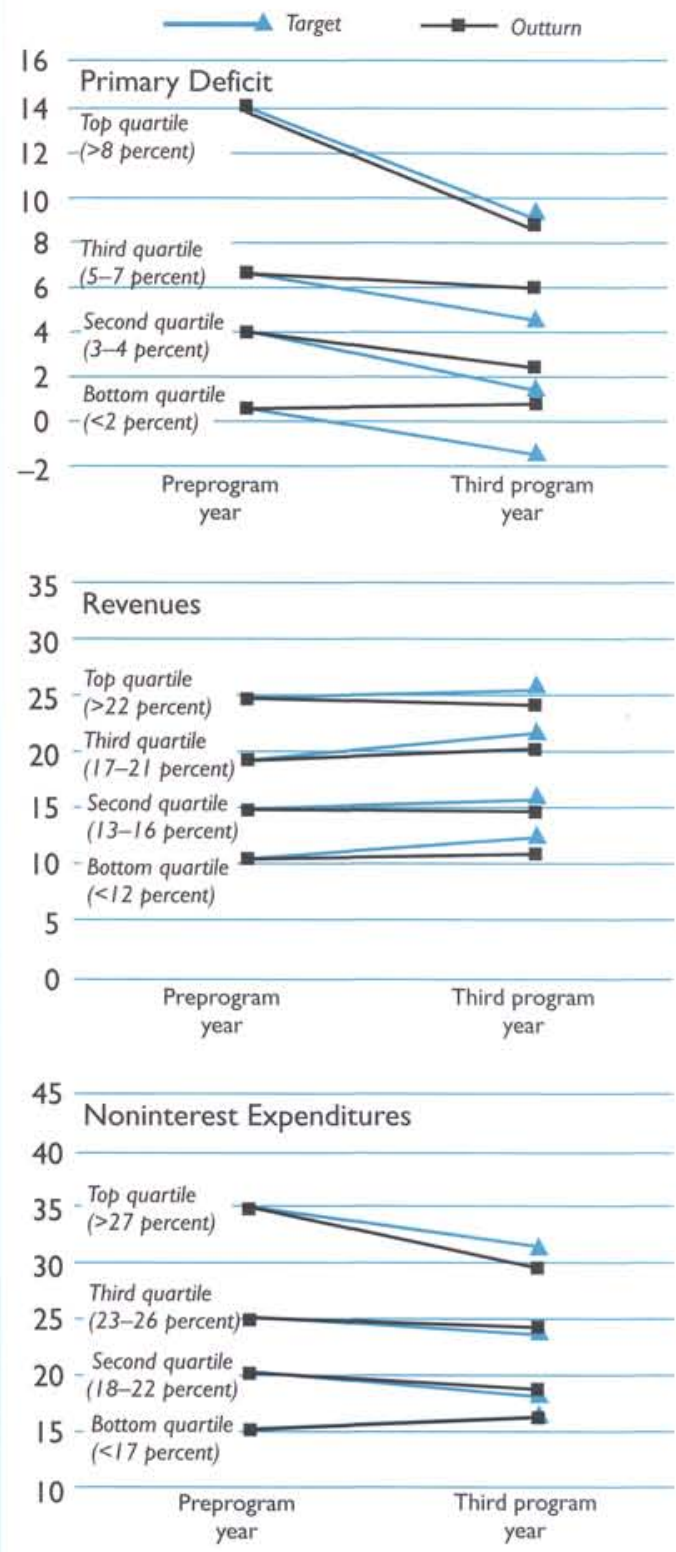

Source: IMF staff estimates.

IBased on the same restricted sample as in Figure 3.

proved customs administration, or the planned tariffication of quantitative trade restrictions.

On average, only about half of the targeted reduction in primary budget deficits was achieved (see 
Figure 3). Performance varied widely, however, with almost half of all programs achieving no improvement in the primary balance over three years. The largest shortfalls, relative to target, appeared in the Western Hemisphere countries, where deficits actually increased as a percentage of GDP (though this partly reflects upward revisions to recorded deficits in the preprogram year). African countries also tended to miss program targets by wide margins, but nevertheless succeeded in reducing their budget deficits from preprogram levels. Revenues fell short of target in roughly two-thirds of all programs, and on average (in relation to GDP) were barely changed from preprogram levels. Somewhat surprisingly, however, deficit overruns were not significantly correlated with revenue shortfalls, reflecting a common tendency for expenditures to be curtailed in programs where revenues failed to meet expectations. The brunt of this expenditure restraint was typically borne by capital spending, which came in below target in three-quarters of the programs experiencing revenue shortfalls (whereas current spending was cut in only one-third). ${ }^{11}$ By contrast, overshooting of deficit targets was more typically associated with expenditure overruns, the latter dominating in twothirds of such cases. ${ }^{12}$

Where program objectives were not met, the reasons were often complex. On the revenue side, targets for direct and indirect taxes were, on average, achieved. The ambition to raise tax receipts from foreign trade, however, was only partially realized in most cases. It appears that early tariff rate reductions were often not accompanied by the planned elimination of import duty exemptions, or by effective measures to tackle evasion. In some cases (notably in Africa), there were also delays in converting quantitative restrictions to tariffs. In an attempt to compensate for tax shortfalls, countries often resorted to one-off measures to boost nontax revenues, increased profit transfers from central banks being a common device.

Expenditure overruns were most prevalent in African and Western Hemisphere countries. Governments frequently failed to scale back civil service headcounts as intended, trying instead to trim wage rates (in conflict with another oft-stated objective:

\footnotetext{
${ }^{11}$ The tendency to sacrifice capital before current spending may arise from the perception that cuts in public investment are politically less costly. For evidence, see Haggard and others (1995).

${ }^{12}$ This assortment of outcomes-with some programs recording expenditure overruns and others a combination of revenue and expenditure shortfalls-explains why, in the aggregate (see Figure 3 ), expenditures appear roughly in line with targets on average, while revenues are lower than targeted. Dicks-Mireaux and others (forthcoming) provide detailed analysis and statistical testing of these findings.
}

retaining and motivating good quality civil servants). Subsidy costs also tended to exceed targets in these countries, in all likelihood reflecting their limited progress in reforming public enterprises. More generally, ESAF countries' expenditure management suffered from weak budgetary institutions-owing in part to a scarcity of trained personnel-with poor systems for budgeting and monitoring of expenditures, and widespread use of extrabudgetary funds.

As regards the evolving composition of government spending in ESAF countries, the record is, on the whole, reasonably positive (Figure 5). Relative to the pre-SAF/ESAF period, the desired shift from current to capital expenditure did occur, albeit to a lesser extent than had been hoped. The tendency to sacrifice capital spending as revenues fell short meant that, rather than rising as intended, capital spending did no more than hold steady as a share of GDP in the nontransition economies as a whole, and declined slightly among ESAF users in Africa. ${ }^{13}$ More encouragingly, the limited data that are available suggest that roughly three-quarters of countries succeeded in raising expenditure on health and education since their SAF/ESAF-supported adjustment began, including (on average) in Africa. Similarly, in the area of military spending there was a broadbased shift in the desired direction, with declines observed since the pre-SAF/ESAF period in 12 of the 15 countries for which data are available, from an average of almost 3 percent to about $2 \frac{1}{2}$ percent of GDP.

\section{Inflation Control}

The diversity of experiences among ESAF countries in reducing inflation is so marked as to preclude generalizations about the sample as a whole. Among regional groupings, however, some clear patterns emerge (Figure 6). ${ }^{14}$

First, countries in the CFA franc zone stand apart, having succeeded in maintaining inflation consistently in the low single-digit range since the mid1980 s, reflecting their use of the exchange rate peg to the French franc as an anchor. The 50 percent devaluation of the CFA franc in January 1994 triggered a price level adjustment in that year, but by 1995 inflation was already back to about 7 percent on average, and it fell further in 1996. ESAF countries in Asia have also had generally stable inflation

\footnotetext{
${ }^{13}$ These averages conceal some notable successes in raising capital spending, however. In Bolivia, Ghana, Mozambique, Nicaragua, and Uganda, the share of capital spending in GDP has increased by at least 4 percentage points since the pre-SAF/ESAF period.

${ }^{14}$ References in this section to "low" inflation mean an annual rate below 10 percent, "intermediate" means $10-40$ percent, and "high" means above 40 percent.
} 
Figure 5. Composition of Government Spending

(Averages, in percent of GDP)

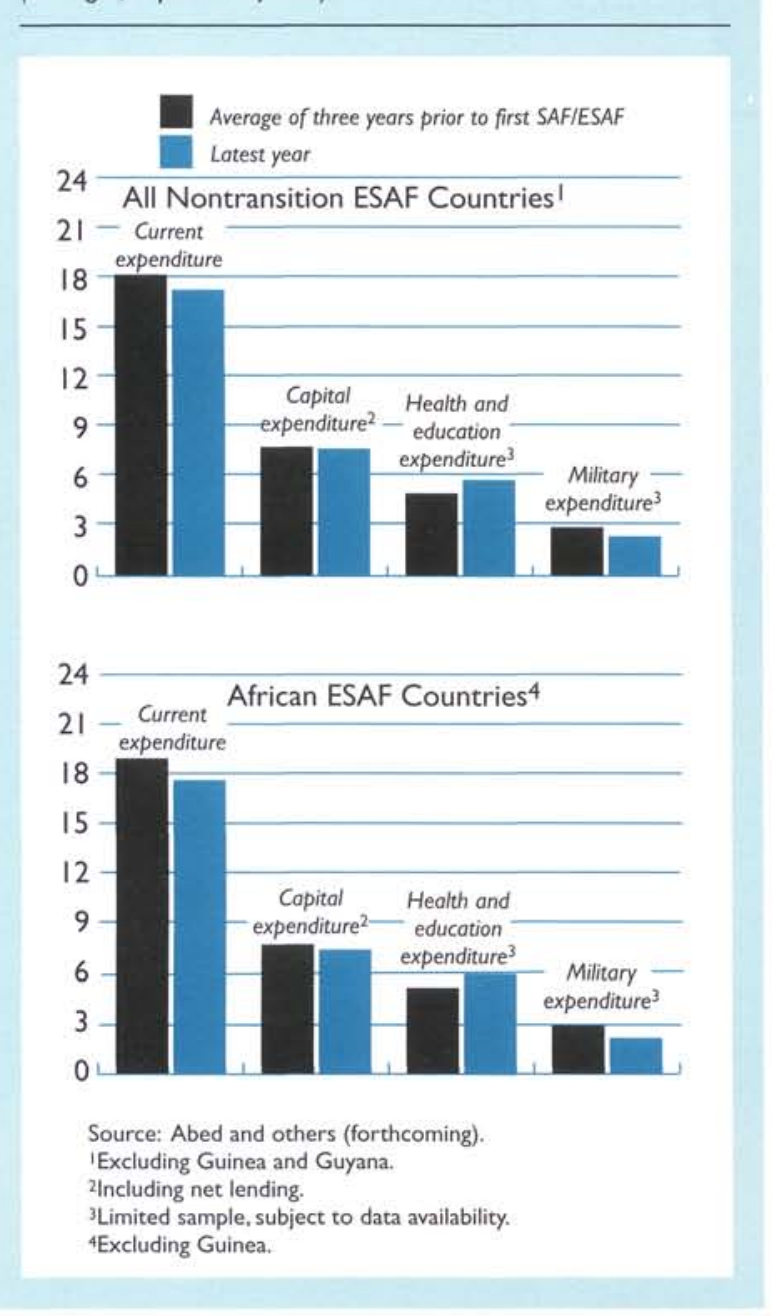

over the past decade, fluctuating within a fairly narrow range around 10 percent.

The three ESAF users in the Western Hemisphere other than Honduras had witnessed very high inflation (above 100 percent) at some point in the past decade, but all extinguished it successfully (Bolivia in 1986 and Nicaragua and Guyana in 1992) and had reached rates in the neighborhood of 10 percent by 1995. ${ }^{15}$ Dramatic disinflation was also achieved in the six transition economies. Following the price surges commonly associated with liberalization, all

\footnotetext{
${ }^{15}$ Bolivia and Nicaragua had largely defeated their near-hyperinflations in earlier programs supported by stand-by arrangements with the IMF, but they consolidated this progress in their subsequent SAF- and ESAF-supported programs.
}

Figure 6. Inflation Trends by Region (CPI, end-of-period basis where available, group medians)'
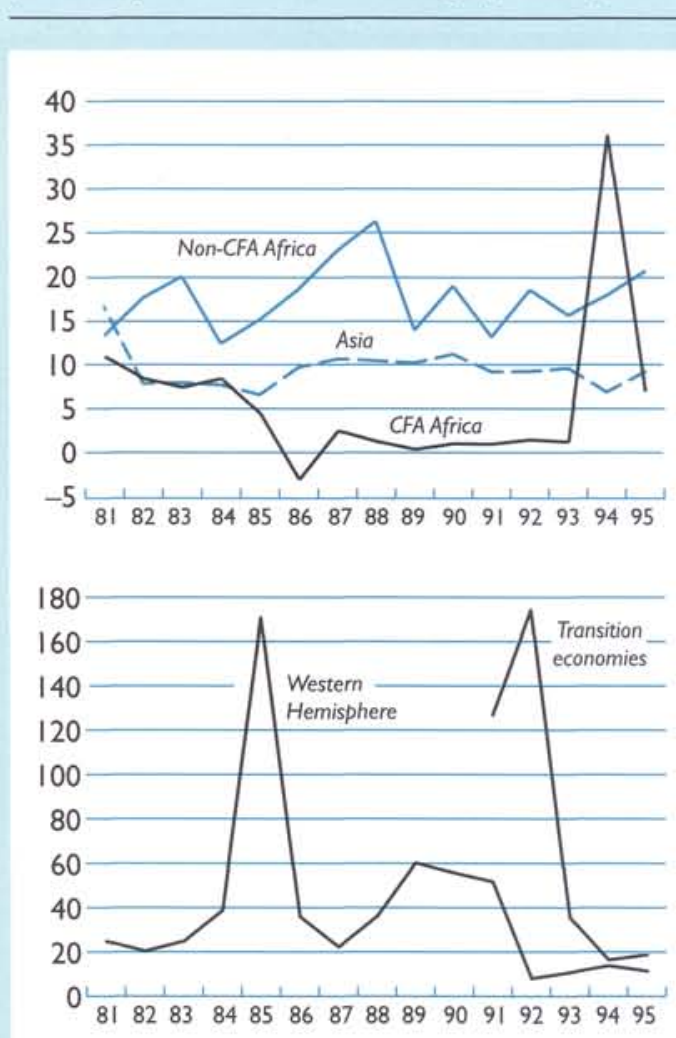

Source: IMF staff estimates.
IWhere end-of-period CPI data are not available, period aver-
age figures are used. In a few cases, the GDP deflator is used.

but Mongolia quickly brought inflation down into the intermediate range, and by 1995 Albania, Cambodia, and Vietnam had rates close to or below 10 percent.

Inflation performance has been most mixed, however, in non-CFA Africa. In a handful of casesThe Gambia, Guinea, Lesotho, Mauritania, and Uganda-a good deal has been accomplished in recent years. These countries each had average inflation rates of below 10 percent during 1993-95compared with rates during the late 1980s that averaged 37 percent, and exceeded 100 percent in Uganda. The region as a whole, however, saw no downward trend in inflation during the $10-15$ years to 1995 . Indeed, the average rate rose during the first half of the 1990s, to over 20 percent by 1995. Several countries witnessed sharp declines in inflation in 1996, although it is too early to say how much of this drop reflects the generally favorable supply con- 
Figure 7. Inflation Targets, by Degree of Initial Inflation'

(Group medians, excluding CFA countries)

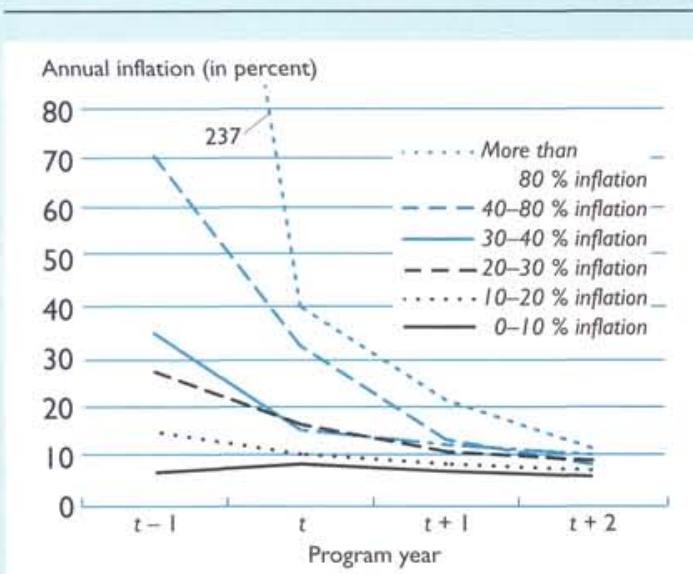

Source: IMF staff estimates.

ITargets set at the beginning of three-year SAF/ESAF-supported programs. Year $t$ is the first program year.

ditions and how much a durable strengthening of macroeconomic policies.

How does this experience compare with what was envisaged in SAF/ESAF-supported programs? Programs typically aimed to bring inflation down to the single-digit range over the three-year arrangement period, with the pace determined to a large extent by the initial level of inflation (Figure 7). In the event, programs had greatest success in tackling high and very high inflations (Figure 8 ). For the most part, however, the intended transition to low inflation was not achieved. Setting aside the CFA franc zone cases, fewer than two programs in five had single-digit inflation by the third program year. This is not much more than the proportion (30 percent of programs) that already had single-digit inflation in the year before the program started. Thus, almost as many countries moved up from the low to the intermediate range during programs as achieved the reverse.

In the majority of those starting with initial inflation in the intermediate range (26 programs, or half of all non-CFA cases), less than one-half of the decline in inflation targeted for the first year was achieved. The picture by the third year was only somewhat better, and there is no systematic evidence of further gains made beyond the program period. Moreover, although inflation rates did tend to decline during programs, it was typically from a peak following several years of rising inflation (see Figure 8): hence the earlier observation that many countries made no perceptible progress in reducing inflation over the longer term. Section IV, considers
Figure 8. Inflation Target and Outturns' (Group medians, in percent; excluding CFA countries)

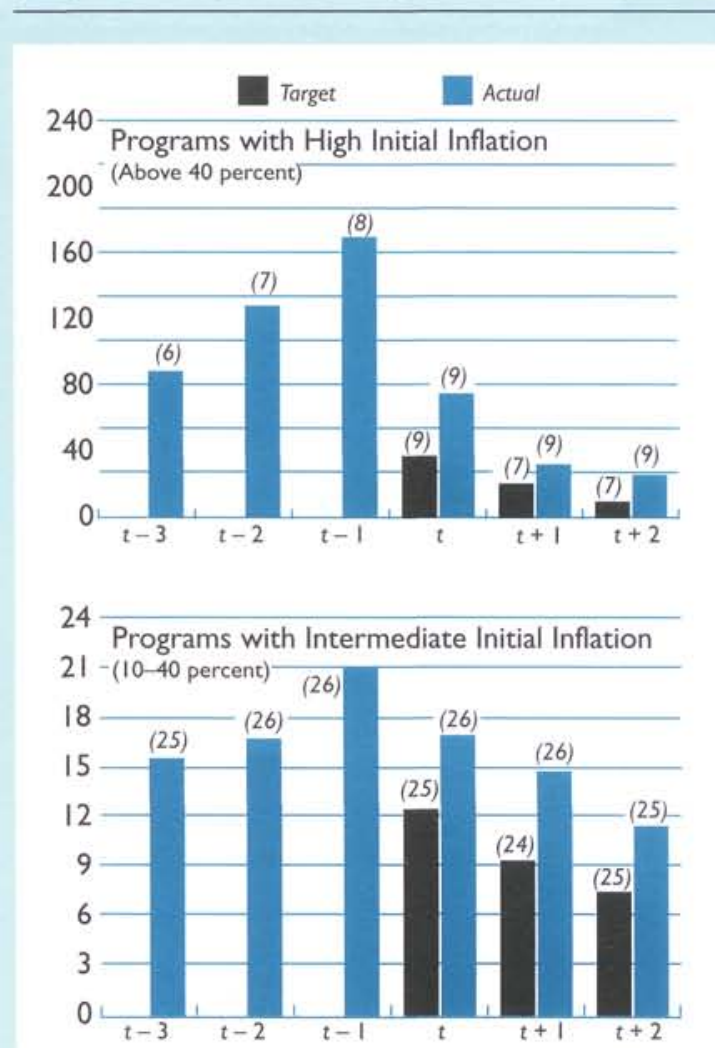

Source: IMF staff estimates.

IFigures in parentheses above bars refer to the number of programs. Year $\mathrm{t}$ is the first program year.

why many ESAF users have remained stuck in the intermediate inflation range (Table 2), and what this implies for program design.

\section{Structural Reform}

At the time of the last review, looking back over the first six years of experience with SAF/ESAFsupported programs, it was concluded that progress in structural economic reform among the countries involved had been profound but uneven. Important gains had been achieved in the areas of exchange and trade liberalization, price-setting and marketing, and the freeing of interest rates. But little had been accomplished in other areas, notably in the restructuring and reform of public enterprises and banking systems.

Four years on, the assessment must be similarly qualified. On the positive side, reforms continued to 
Table 2. Progress on Inflation Since the Pre-SAF/ESAF Period' (In percent)

\begin{tabular}{|c|c|c|}
\hline & $\begin{array}{c}\text { Average Inflation } \\
\text { During Three Years Prior to } \\
\text { First SAF/ESAF Program }\end{array}$ & $\begin{array}{l}\text { Average } \\
\text { Inflation, } \\
\text { 1993-95 }\end{array}$ \\
\hline CFA franc zone Africa, median & 1.4 & $16.5^{2}$ \\
\hline \multicolumn{3}{|l|}{ Other ESAF users } \\
\hline \multicolumn{3}{|l|}{ "Stronger performers"3 } \\
\hline Albania & 170.4 & 17.6 \\
\hline Bangladesh & 10.2 & 4.7 \\
\hline Bolivia & $3,471.2$ & 10.1 \\
\hline Gambia,The & 34.6 & 1.4 \\
\hline Guinea & 71.8 & 4.2 \\
\hline Guyana & 63.6 & 10.6 \\
\hline Lesotho & 14.4 & 8.0 \\
\hline Mauritania & 8.8 & 4.4 \\
\hline Nepal & 11.0 & 8.2 \\
\hline Sierra Leone & 70.3 & 24.0 \\
\hline Sri Lanka & 6.9 & 8.7 \\
\hline Uganda & 155.3 & 8.3 \\
\hline \multicolumn{3}{|l|}{ "Weaker performers" } \\
\hline Burundi & 8.8 & 14.3 \\
\hline Ghana & 19.6 & 44.2 \\
\hline Honduras & 23.0 & 22.9 \\
\hline Kenya & 7.4 & 22.7 \\
\hline Lao People's Democratic Republic & 18.2 & 13.8 \\
\hline Madagascar & 11.6 & 35.6 \\
\hline Malawi & 19,4 & 53.1 \\
\hline Mongolia & 177.0 & 100.8 \\
\hline Mozambique & 32.7 & 56.0 \\
\hline Pakistan & 5.4 & 11.4 \\
\hline Tanzania & 33.9 & 26.9 \\
\hline Zimbabwe & 20.2 & 21.9 \\
\hline \multicolumn{3}{|l|}{ Source: IMF staff estimates. } \\
\hline \multicolumn{3}{|c|}{ d'Ivoire, the Kyrgyz Republic, Nicaragua, and Vietnam). } \\
\hline \multicolumn{3}{|c|}{${ }^{2}$ This figure reflects the CFA franc devaluation in early 1994; the 1995 median was 6.4 percent. } \\
\hline \multicolumn{3}{|c|}{$\begin{array}{l}{ }^{3} \text { Countries that achieved average single-digit inflation during 1993-95, or (in the case of Albania, Bolivia, Guyana } \\
\text { nd Sierra Leone) that had brought inflation down very sharply from high preprogram levels. }\end{array}$} \\
\hline
\end{tabular}

move ahead on all fronts and in all countries, to varying degrees. Equally important, there are few instances of substantial policy reversals. Thus, although the process has been long and drawn out in many cases, the countries concerned now have economies that are significantly more market driven and flexible than they were 10 years ago. There are also signs that the pace of structural reform has picked up in recent years, especially in Africa (Figures 9 and 10). It remains the case, however, that reforms affecting bank soundness and public enterprises lagged far behind other areas and fell short of program ambitions: these are also among the areas in which African economies compare least favorably with other ESAF countries. (The judgments in this section regarding the extent and pace of structural reform are based primarily on "policy indices," the construction of which is summarized in Box 4.)

The deregulation of pricing and marketing was among the earliest of structural reforms to be implemented in SAF/ESAF-supported programs (and some countries had made significant advances in prior adjustment programs). Major successes were achieved early on, particularly in the important markets for agricultural products. Progress since then has continued; by 1995 instances of the most extensive intervention had been eliminated, although onethird of ESAF countries still had controls on a few staple foodstuffs, transportation, utilities, petroleum 
Figure 9. Status of Structural Reform in ESAF Countries (Indices of structural reform)
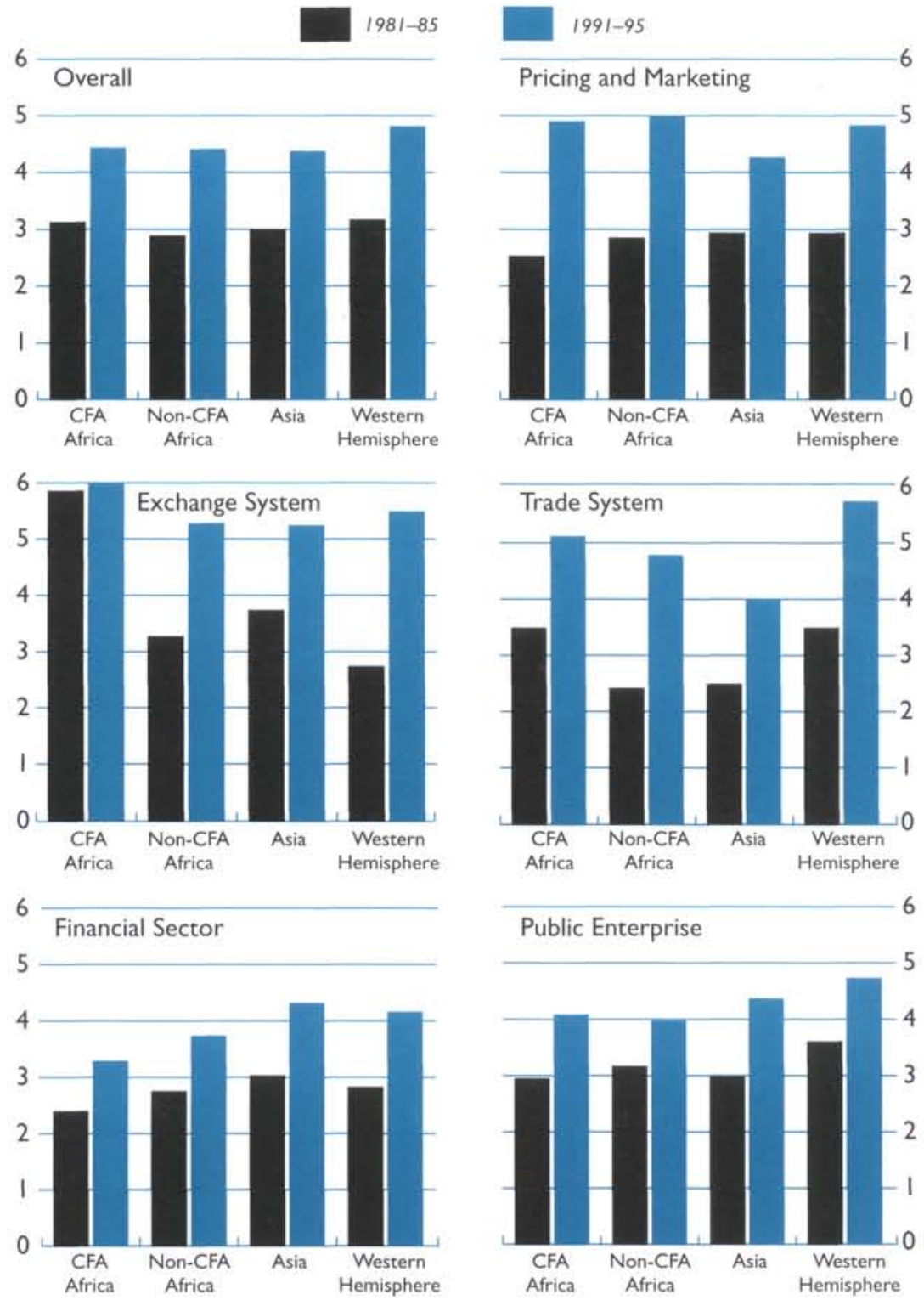

Source: Dicks-Mireaux and others (forthcoming).

"Higher values of the indices denote lower distortions ("better" policies).

products, and some construction materials. There has also been a widespread shift to more rational mechanisms for setting prices that remain subject to controls, with petroleum prices now commonly linked to world prices, and utility rates typically set on a cost recovery or long-run marginal cost basis. One important area where the pace of reform accelerated in recent years is in the pricing and marketing of export products, which were heavily controlled in almost half of all nontransition ESAF countries in 
Figure 10. The Pace of Structural Reform (Change in indices of structural reform)!
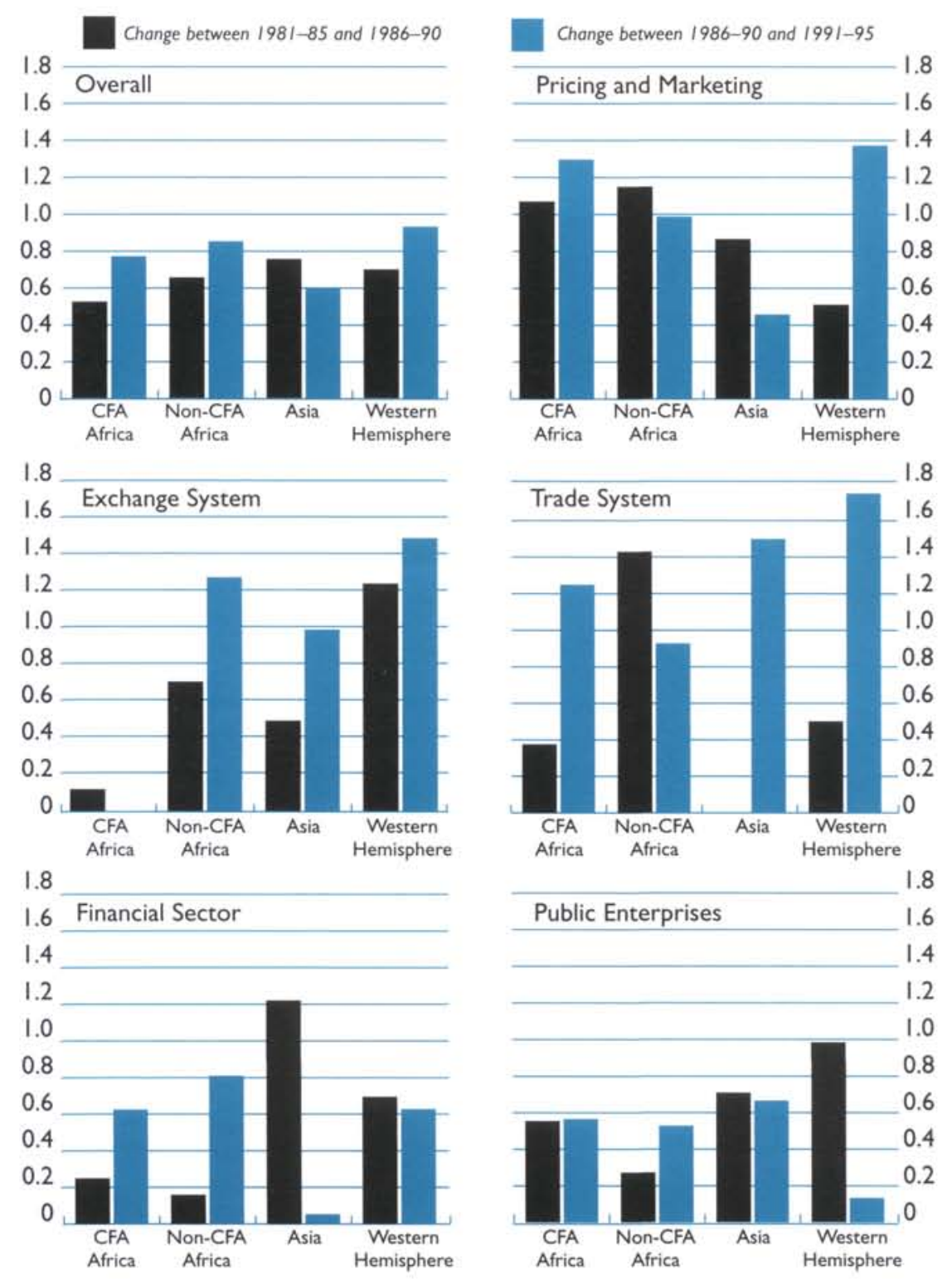

Source: Dicks Mireaux and others (forthcoming)

'Higher values of the indices denote greater improvement in structural policies or decline in distortions.

the early 1980 s and which are now universally subject, at most, to light or moderate intervention. In general, with a few exceptions, price reform is an area where Africa has outpaced other ESAF countries since the early 1980 s.
Rapid progress has also been commonplace in the reform of ESAF countries' exchange systems. Already by 1990 , extensive use of surrender requirements and controls on the allocation of foreign exchange was confined to only four of the nontran- 


\section{Box 4. Indices of Structural Reform}

The five indices of structural reform shown in Figures 9 and 10 are each based on a number of criteria:

- Pricing and marketing. The extent of price controls and state intervention in marketing of fertilizers, petroleum products, major foodstuffs, and export products.

- Exchange system. The level of the premium in the parallel exchange market and the extent of surrender requirements and nonmarket foreign exchange allocation.

- Trade system. The coverage of quantitative restrictions and the level and dispersion of tariffs.

- Financial sector. The presence or otherwise of controls on credit or interest rates; real interest rates and interest rate spreads that are above or below certain thresholds; quantitative measures of financial intermediation, private sector access to credit, and financial deepening; and the existence or otherwise of a diversified banking system and markets for interbank funds, government or central bank securities, and stocks.

- Public enterprise sector. Measures of public enterprises' share in total output and total credit, of their overall financial balance, and of net financial flows from government.

The detailed methodology for scoring against and weighting these criteria is explained in DicksMireaux and others (forthcoming).

sition ESAF countries (Bangladesh, Mauritania, Tanzania, and Zimbabwe). ${ }^{16}$ By 1995 such distortions had been eliminated in all nontransition countries except Madagascar, and currently all except Burundi, Lesotho, Mauritania, and Mozambique have accepted the obligations of Article VIII of the Fund's Articles of Agreement. ${ }^{17}$ Foreign exchange markets in many countries remain subject to restrictions on capital transactions, however, as indicated by the persistence of parallel market premiums exceeding 10 percent in two-thirds of Asian and nonCFA African ESAF countries in 1995.

The easing of trade barriers was somewhat slower in coming, beginning typically in the late 1980s, but accelerating in the early 1990s. Non-CFA African countries had the most severe initial distortions in this area, but subsequently made faster progress than any other region, and by 1995 almost all had put in place regimes that were in many respects less

\footnotetext{
${ }^{16}$ Countries in the CFA franc zone had foreign exchange systems that were free of restrictions on current transactions throughout the period under review.

${ }^{17}$ Among ESAF transition countries, the Krygyz Republic and Mongolia have also accepted the obligations of Article VIII.
}

protective than the average Asian ESAF user. ${ }^{18}$ In the CFA countries, the pace of trade reform benefited from the impetus provided by the 1994 devaluation of the CFA franc and by new regional initiatives aimed at expanding trade links in that part of the world. Overall, significant progress was achieved in curtailing quantitative restrictions: the number of countries making extensive use of such highly distorting instruments declined from 14 in the early 1980 s to 7 by 1990 and zero by 1995 . The rationalization and reduction of tariff rates typically proceeded more slowly. The pace picked up in the early 1990 s with important reforms in a number of countries (Benin, Ghana, Guinea, Honduras, Kenya, and Togo), although many countries supplemented tariffs with other taxes, customs fees, and duties targeted at imports. Notwithstanding the generally encouraging trends, there is great scope for further gains in trade reform through tariff reductions: as of 1995 , trade regimes remained "moderately restrictive" in half of all nontransition ESAF countries. 19

A more sobering impression emerges from the experience with public enterprise reform. This has been an important element in SAF/ESAF-supported programs, since the losses imposed by public enterprises on the state budget and the banking system have been of macroeconomic proportions. Although in some countries the planned measures were piecemealaimed at selected problem enterprises - as many as two-thirds of the countries under review developed comprehensive public enterprise reform plans, typically in collaboration with the World Bank. The key elements of the strategy were as follows:

- Hardening budget constraints on public enterprises, by limiting their recourse to capital transfers, direct subsidies, and net lending from government and to credit from the banking system.

- Creating the conditions for more management accountability in public enterprises, either by entering into "performance contracts" with existing managers or by contracting out management responsibilities to the private sector.

- Enhancing competition to encourage efficiency gains in public enterprises and to pave the way for privatization, through the lifting of restrictive regulations on pricing and investment, and removal of de jure barriers to entry.

- Privatization of selected (usually small and medium-sized) enterprises; divestment plans typically excluded "strategic" enterprises-those in

\footnotetext{
${ }^{18}$ The indices of trade reform do not, however, capture use of nontariff import charges (see below).

${ }^{19}$ In this context, "moderately restrictive" means a tariff structure with average tariff rates of $20-25$ percent (maximum $30-40$ percent) and few exemptions.
} 
utilities, telecommunications, transportation, heavy industry, and agricultural processing and marketing - which were usually targeted instead for restructuring under state control.

- Building social and political consensus for the reforms, including through the process of negotiating policy framework papers with World Bank and IMF staff (and dialogue during staff visits more generally) and by provision of social safety nets. ${ }^{20}$

Overall, the implementation of public enterprise reform has been slow, uneven, and subject to extensive slippages. The size and financial burden of public enterprises (according to the limited available data) have been reduced in roughly half of the nontransition ESAF countries since the early 1980s, and the number of countries with a severe burden in this respect has fallen sharply. However, despite the finding of the last review that this is an area where greater efforts were needed, only in non-CFA Africa is there any evidence of an accelerated pace of reform in the 1990s. Even in non-CFA Africa, progress has been variable: based on available indicators, half of the countries appear to have made little or no progress during the past 10 years.

Poor results can be traced to the fact that the biggest problems - both from a financial and a resource allocation perspective-typically reside in the strategic sectors, where the standard approach has had least effect. Many countries (especially the transition economies) have made significant progress in privatizing small and medium-sized enterprises, but few (Bolivia and Ghana are exceptions) have divested large enterprises in the strategic sectors. Meanwhile, attempts at restructuring the large enterprises have not delivered the desired results. Managers do not appear to have changed their ways in response to the introduction of performance contracts, which have often been poorly designed. And governments have tended to replace direct budgetary support with quasi-fiscal assistance such as tax concessions and loan guarantees, thereby reducing pressure on the enterprises to reform. It is encouraging that recognition of these weaknesses appears to be growing, and recent programs have tended to put greater emphasis on privatization of strategic enterprises, including through leasing arrangements.

Reforms of the financial system in SAF/ESAFsupported programs have had three broad and complementary aims: to move from state to market allocation of credit; to substitute indirect for direct

\footnotetext{
${ }^{20} \mathrm{All}$ five of the countries examined in the case studies reported in Decressin and others (forthcoming) provided some form of assistance-usually severance benefits, but sometimes also retraining support-for employees laid off during restructuring of public enterprises.
}

instruments of monetary control; and to strengthen banks' financial positions on a durable basis. In the event, achievements have been mixed, with least progress in what is perhaps ultimately the most important aspect: bank soundness. Reforms to liberalize interest rates were enacted early and are now widespread, encompassing two-thirds of nontransition countries in 1995 (with remaining controls confined largely to Africa). As a result, the prevalence of negative real interest rates has diminished sharply outside non-CFA Africa. The development of financial markets-for interbank funds, government securities, and stocks - and the transition to indirect instruments of monetary control have also proceeded well, beginning in the late 1980s (Asian countries made particularly strong and rapid progress here). The number of countries with formal quantitative controls on credit dropped from almost half of all nontransition countries in 1990, and all but five countries in the early 1980 s, to only seven by 1995 .

Weaknesses in the banking systems in ESAF countries, however, remain pervasive. Though data are extremely scarce, the extent of balance sheet problems has become increasingly apparent over the past decade as banks' principal clients, the public enterprises, suffered from the terms of trade declines of the late 1980s and the squeezing of financial aid from state budgets. Banking (liquidity) crises have been avoided in most countries, probably owing to the perception of implicit government guarantees, but banks' ability to mobilize and allocate resources efficiently has been severely impaired in cases where loan portfolios are fundamentally unsound. At the root of these difficulties has been-in addition to the continuing financial problems of borrowers in the public enterprise sector-a combination of governmental interference in bank operations, weak managers and management systems, and poor regulatory and supervisory frameworks.

Most countries have adopted multiyear bank restructuring plans, in the context of ESAF-supported programs, aimed at addressing inadequacies in each of these areas. The dominant approach has involved government assumption of problem loans and recapitalization, some cost-cutting and downsizing of operations, the introduction in state banks of performance or management contracts to improve decision making, and the strengthening of supervision. Privatization has been limited, as has resort to bank liquidations (except in some CFA countries). Although many of these programs are ongoing, or are too recent to allow an assessment, the results of those in the vanguard have not been encouraging. The fiscal costs, where they are known at all, have been large - on the order of 15-25 percent of GDP in some cases. Yet progress has been slow and fitful, and it has rarely been possible to point to significant 
improvements in the functioning of banks. Reforms appear to have been held back by a dearth of local banking skills, a failure to expand competition in the banking sector, and an unwillingness of governments to stop pressuring banks to lend to uncreditworthy public enterprises.

There has been increasing recognition that an important element in the move to market-based economies is the strengthening of property rights and other aspects of good governance. Legal systems and practices are needed to define clearly and enforce property rights, to ensure respect for contracts, and to deter corruption and abuse of authority. ESAF-supported programs have made a positive contribution in this regard, both directly (promoting reform of land tenure systems and more liberal and transparent foreign investment codes, for instance) and indirectly (by reducing the extent of the distortions and regulations that feed corruption). Assessing overall progress in this area is particularly difficult, however. Dicks-Mireaux and others (forthcoming) report some evidence, based on ratings by commercial agencies according to various "economic security" criteria. ${ }^{21}$ These suggest a mixed picture among ESAF countries: property rights appear to have improved in recent years (comparing the early 1990s with the late 1980s) in two-thirds of countries, but deteriorated in one-third. The improvements seem to have been concentrated in Asian and Western Hemisphere countries, although some countries in Africa (Ghana, Tanzania, and Uganda) have also made considerable progress in this area.

\section{Openness}

This survey of evolving policies tells a story of qualified progress over the past decade among countries pursuing SAF/ESAF-supported programs. There were consistent but often hesitant advances in most policy areas, disappointments in some respects and in some countries, but signs of a general strengthening of the adjustment effort in the early 1990 s. Progress in increasing the outward orientation of ESAF countries' economies - an important strategic objective-was similarly modest, but with signs of an improving trend in recent years.

Liberalization of exchange and trade regimes, nominal depreciation, and fiscal adjustment were reflected in a steady and sizable depreciation of the real exchange rate across all regions from 1985 onward (Figure 11). Real depreciation was particularly

\footnotetext{
${ }^{21}$ The criteria are the quality and acceptance of the tools of law and order, the quality of public administration and extent of government corruption, and contract and expropriation risks to foreign investors.
}

sharp in the Western Hemisphere and least pronounced in CFA Africa until the devaluation of the CFA franc at the beginning of 1994. Notwithstanding substantial cross-country variation, parallel market premiums on the whole also declined markedly over this period as exchange regimes were liberalized. Regional differences also narrowed significantly, reflecting marked progress in those regionsnon-CFA Africa and Western Hemisphere-that had the most distorted exchange regimes in the early 1980 s, and comparatively little progress in Asia. ${ }^{22}$

These developments contributed to a sizable expansion from the mid-1980s onward in the degree of openness - as measured by the level of foreign trade in relation to GDP-in non-CFA Africa and the Western Hemisphere. In Asia, where the trade ratio is smaller owing to the much larger size of these countries, the increase has been less pronounced, as overall output grew in line with relatively rapid growth in trade..$^{23}$ In CFA Africa, foreign trade flows picked up following the devaluation in 1994.

A somewhat different regional picture, however, emerges from an analysis of trade volumes. In all regions, with the striking exception of Asia, export volumes had been stagnant or declining during the early 1980 s and picked up only modestly in the second half of the 1980s (Figure 12). On average, countries in Africa and the Western Hemisphere incurred major losses in export market share throughout the 1980s. These losses were stemmed in the early 1990s, however, as export volume growth in the two regions accelerated to over 7 percent, and significant gains in market share were recorded by a number of countries (including Ghana, Kenya, and Tanzania). By contrast, export market share rose steadily and markedly in Asia from 1985 to 1995.

Stronger export growth and increased resource transfers allowed import volumes to rebound in Africa in the mid- to late 1980 s, following a period of severe compression. In Asia and the Western Hemisphere, import growth was subdued or declining until the early 1990 s, when it rose sharply as a counterpart to booming exports in these regions.

\section{Economic Growth}

This broad picture is closely mirrored in ESAF countries' growth performance over time. From

\footnotetext{
${ }^{22}$ Countries in the CFA franc zone had negligible premiums throughout, owing to the absence of significant exchange restrictions in CFA franc regime,

${ }^{23}$ The average population in Asian ESAF countries is 6 to 15 times larger than the average population in African or Western Hemisphere ESAF countries.
} 
Figure II. Share of Trade in GDP and Exchange Rates

(Sample medians)

160 Real Effective Exchange Rate

140 -(Index 1980 = 100)

120 -

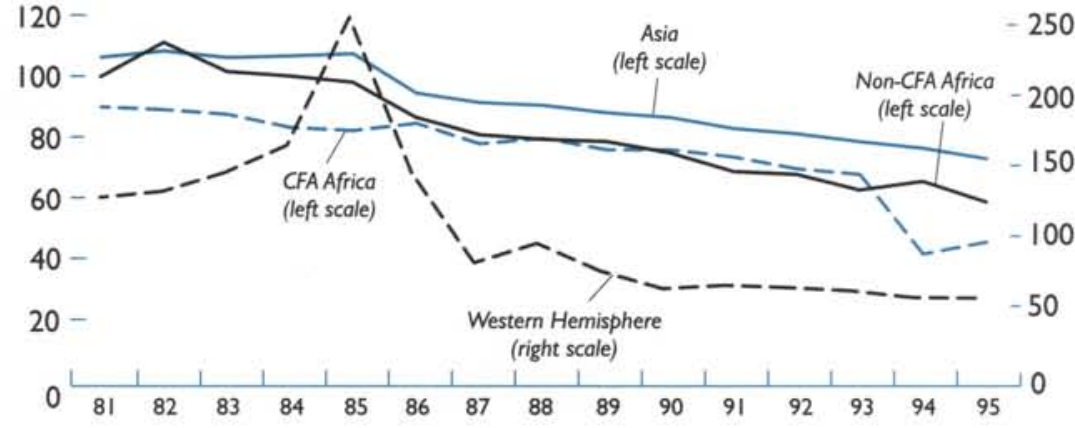

120 Parallel Market Exchange Rate Premium

100 - (In percent)

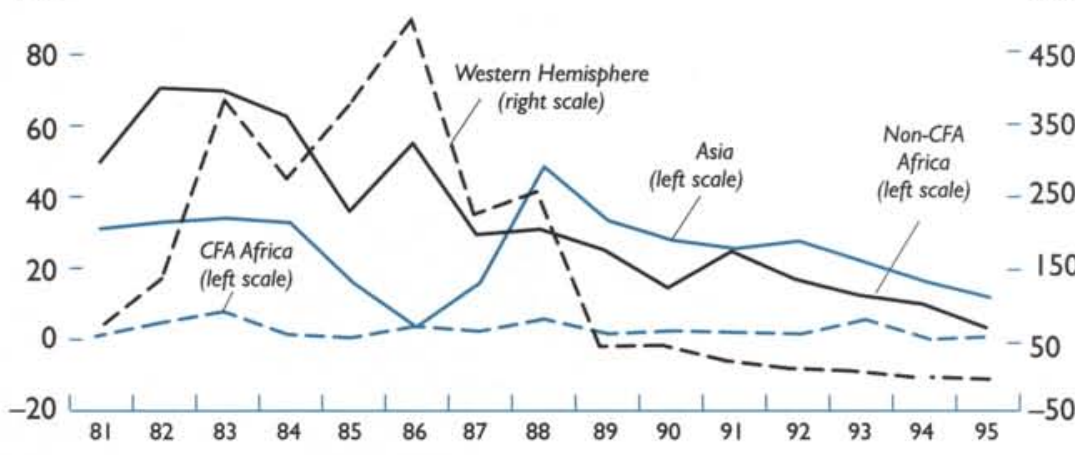

100 Share of Trade in GDP

80 - (In percent)

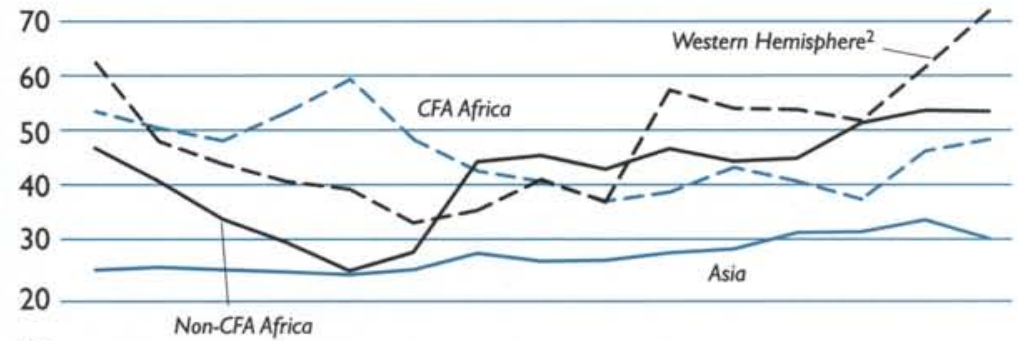

10

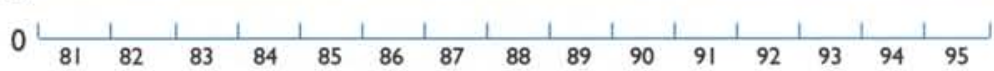

Sources: International Monetary Fund, World Economic Outlook; and IMF staff estimates.

ICalculated as the sum of exports and imports in percent of GDP.

2Excluding Guyana. 
Figure 12. Trends in External Trade

(Sample medians)
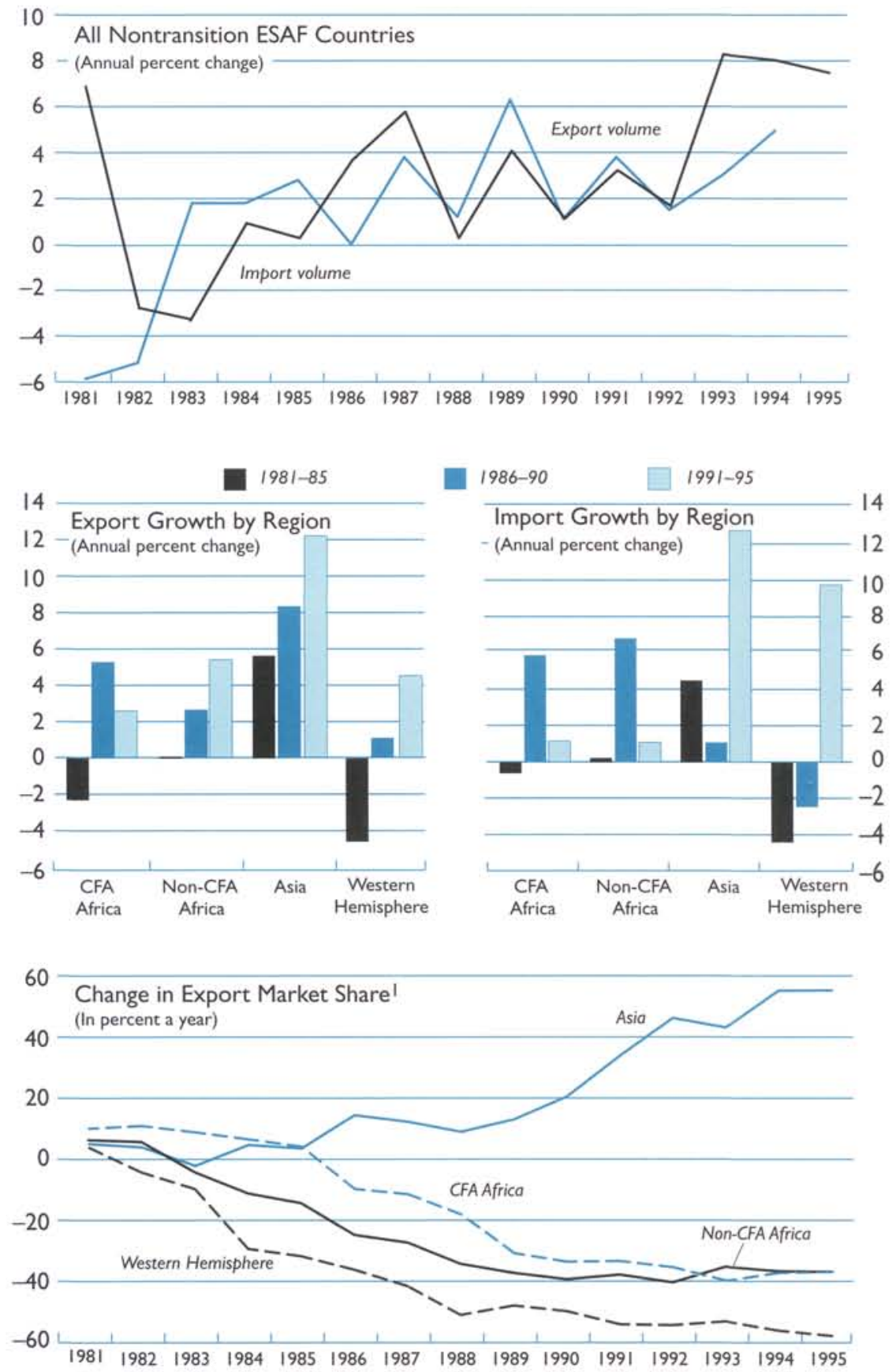

Sources: International Monetary Fund, World Economic Outlook; and IMF staff estimates.

'Difference between export volume growth and growth in partner countries' real import volumes (as defined in World Economic Outlook), compounded from 1980. 
Figure 13. Real Per Capita GDP Growth (In percent a year)

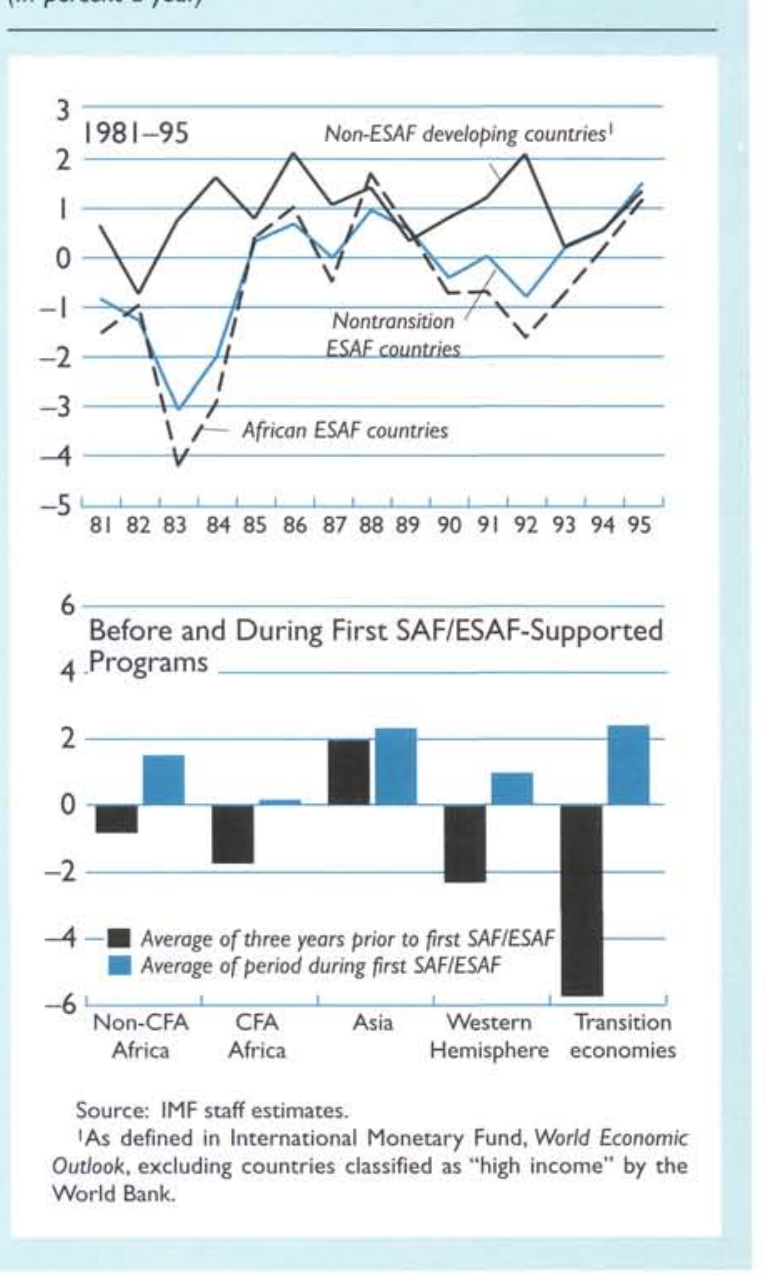

the trough of the early 1980 s, when real per capita GDP declined at an average of almost $1 \frac{1}{2}$ percent a year in nontransition ESAF countries, growth rose to a modest positive rate of around 0.3 percent a year in the early 1990s (Figure 13). ${ }^{24}$ During 1994-95 - aided by a sharp rise in world demand, improved terms of trade, and the realignment of the CFA franc-average per capita growth exceeded 1 percent, and it remained strong in 1996.

The improving trend also helped to narrow the gap between growth in ESAF users and other developing countries. In the early 1980 s, annual average

\footnotetext{
${ }^{24}$ The turnaround is greater still when expressed in terms of median growth rates, which rose from -1.9 percent a year in $1981-85$ to 0.6 percent a year in 1991-95. The difference reflects a more asymmetric distribution of growth rates in the recent period.
}

Figure 14. Growth, Saving, and Investment (Period averages)
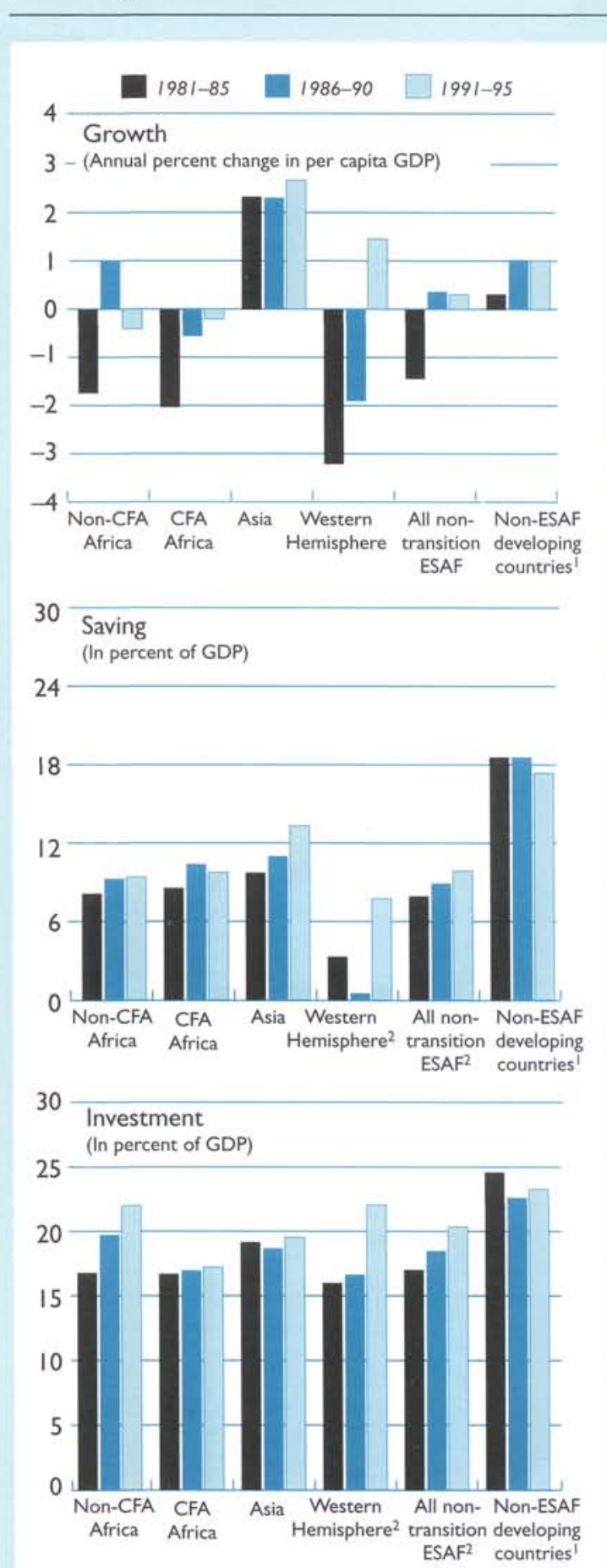

Sources: International Monetary Fund, World Economic Outlook; and IMF staff estimates.

'As defined in World Economic Outlook, excluding countries classified as "high income" by the World Bank.

2Excluding Guyana. 
Figure I5. Social Indicators of Development (Period averages)

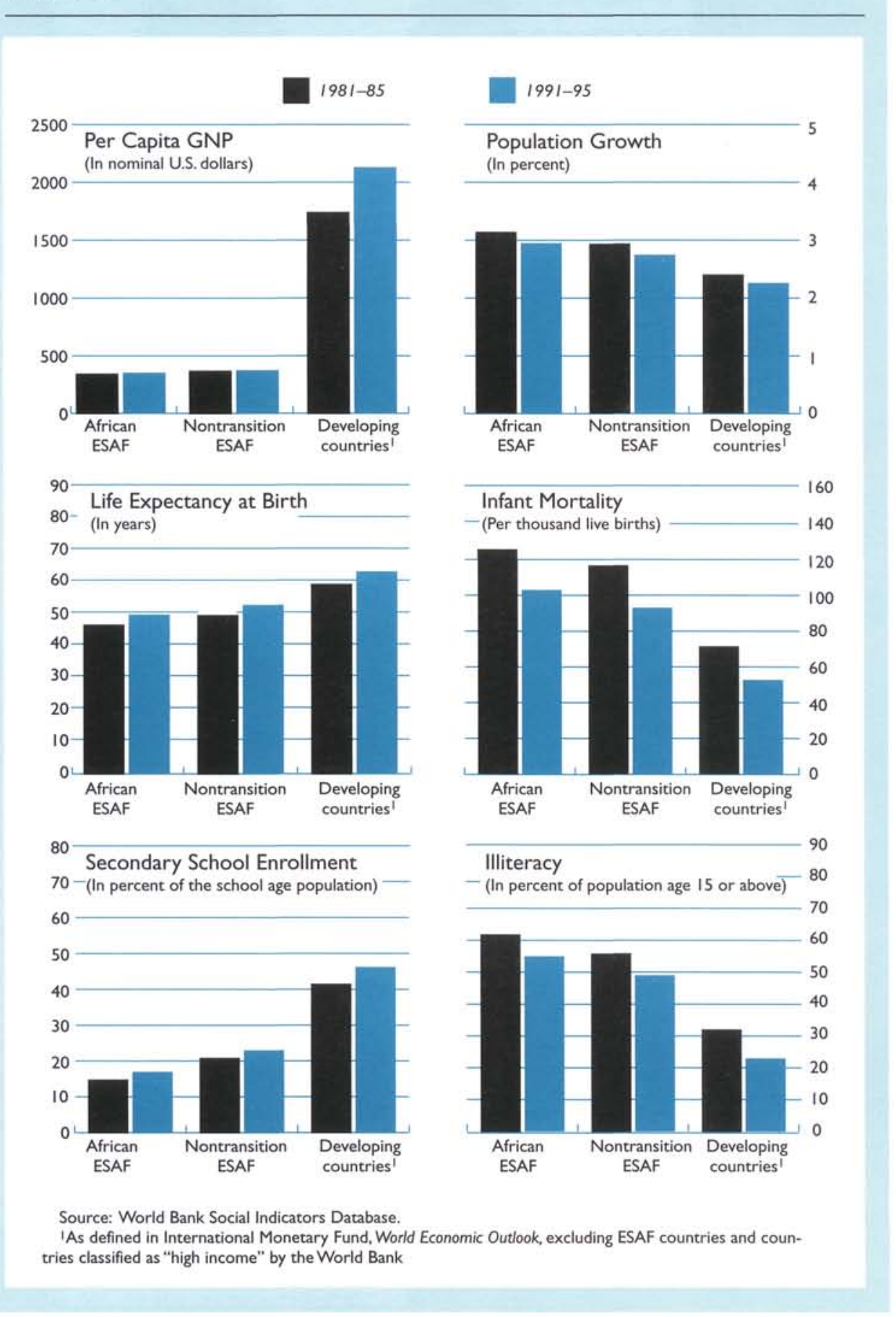

per capita growth in non-ESAF developing countries exceeded that in nontransition ESAF countries by around 2.2 percentage points: this differential had been more than halved, to 0.9 point, by
1991-95. The turnaround in growth typically began remarkably quickly as countries embarked on their first SAF/ESAF-supported programs (see Figure 13, bottom panel). Saving and investment rates in 
ESAF countries showed some measure of convergence too with respect to other developing countries, although ESAF users continue to have much lower saving rates than other countries (Figure 14).

Important as these gains are, there are other perspectives that suggest a less sanguine assessment. First, and most obviously, since ESAF countries' output expanded less rapidly than in the rest of the developing world over the past decade, their average level of per capita income (which was only about one-quarter the average in other developing countries in the early 1980s) fell further behind. Other development indicators depict an improvement in living standards in ESAF countries since the early 1980 s but, again, without narrowing the gap vis-àvis the other countries (Figure 15).

Second, not all countries or regions within the ESAF group shared in the recovery to the same extent. The turnaround in economic growth was most pronounced among the four Western Hemisphere countries, especially Bolivia and Guyana. By contrast, ESAF users in Africa-the poorest in the sample - saw, on average, a smaller degree of convergence toward the developing country mean (see Figure 14). The averages, however, even within Africa, mask a large dispersion-one that widened significantly between the early 1980 s and early 1990s. Of the 22 African ESAF countries, as many as 7-Equatorial Guinea, Ghana, Guinea, Lesotho, Mozambique, Tanzania, and Uganda-had real per capita GDP growth that exceeded the average of all developing countries over the 10 years ending in 1995. In some, the excess was by a wide margin. ${ }^{25}$

This prompts the question of what motivated the recovery in growth among ESAF users over the past 10 years. How much was due to good fortune, and how much to good policies? In Coorey and Kochhar (forthcoming), the comparative growth experience of ESAF and other low- and middle-income developing countries is examined using a standard empirical model based on the now extensive literature on this subject. This study reveals, importantly, that the behavior of growth in ESAF countries-its responsiveness to policies, terms of trade shocks, differences in social and demographic factors, and so on-does not differ fundamentally from that in other

\footnotetext{
${ }^{25}$ Uganda's real per capita GDP growth averaged 3.7 percent a year between 1986 and 1995, compared with an average of 0.9 percent for all developing countries. All four Asian ESAF users also had growth well in excess of the developing country average over this period. Although full time-series data are not available for the transition economies, those in Indochina (Cambodia, the Lao People's Democratic Republic, and Vietnam) recorded average real per capita growth of over 4 percent during 1991-95.
}

Figure 16. Explaining Increases in Growth Since the Early 1980 s

(Change in annual average real capita GDP growth between 1981-85 and 1991-95)

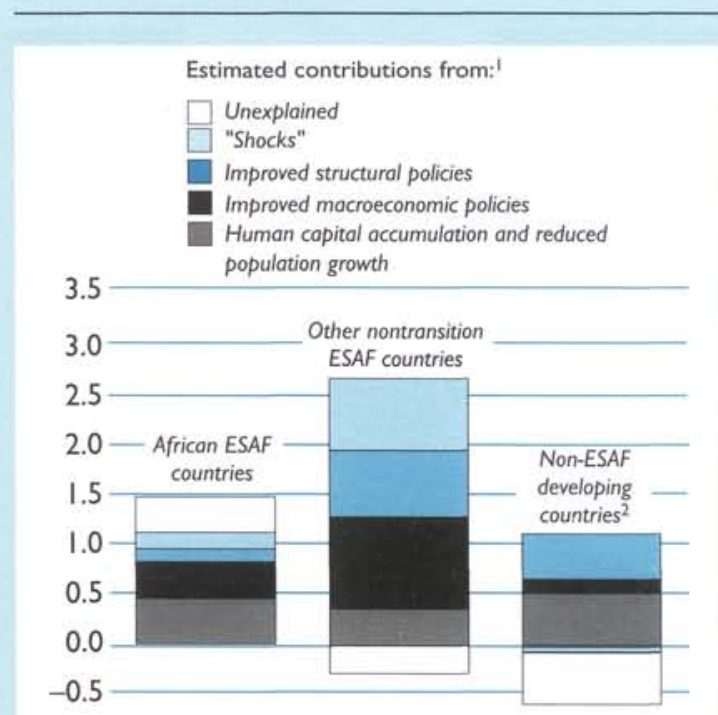

$-1.0$

Source: Coorey and Kochhar (forthcoming).

IEstimated contributions to changes in growth rates are derived from an econometric equation relating per capita GDP growth to a range of determinants estimated on pooled annual data from 198 । to 1995 for 84 low- and middle-income developing countries. In this figure, "macroeconomic policies" combine the effects of changes in inflation and the budget balance; "structural policies" combine openness to foreign trade, size of government, and economic security; "shocks" include changes in the terms of trade and dummies for weather and war or civil unrest. The unshaded portion in each bar is the portion of the change in growth that the estimated equation does not explain. The total change in growth between 1981-85 and 1991-95 is equal to the difference between the height of the bar above and below the zero axis.

2The 84 low- and middle-income developing countries, excluding ESAF countries.

developing economies: ESAF countries are not "special" in this respect. ${ }^{26}$

The estimated relationships are subject to sizable margins of error and, as is common with this kind of analysis, they leave a large portion of the variation in growth over time and across countries unexplained.

${ }^{26}$ Formally, in a growth equation estimated on pooled data for a large sample of developing countries, the hypothesis of stable parameters between the ESAF sample and other developing countries could not be rejected by the data. Also, a dummy variable distinguishing ESAF from other countries was not significant. The policy and other variables used in this analysis are listed in the notes to Figure 16. 
Table 3. Per Capita GDP Growth in 1991-95: Differentials Relative to NonESAF Developing Countries'

(Percentage points, annual averages)

\begin{tabular}{lcc}
\hline & $\begin{array}{c}\text { African ESAF } \\
\text { Countries }\end{array}$ & $\begin{array}{c}\text { Other ESAF } \\
\text { Countries }\end{array}$ \\
\hline Differential in real per & & \\
capita GDP growth & -0.6 & 1.8 \\
Of which, due to: & & \\
Macroeconomic & & \\
$\quad$ policies & 0.2 & -0.2 \\
Structural policies & -0.4 & 0.0 \\
Population growth & -0.8 & -0.2 \\
Human capital & -1.2 & -0.1 \\
"Catch-up" & 1.5 & 0.7 \\
Shocks & 0.1 & 0.2 \\
Unexplained & 0.0 & 1.3 \\
& &
\end{tabular}

Source: Coorey and Kochhar (forthcoming).

IThe sample of 84 low- and middle-income developing countries used in the growth regression, excluding ESAF countries.

${ }^{2}$ See Figure 16, footnote 1, for an explanation of these estimates. The "catch-up" term represents the estimated amount by which growth in the countries concerned would exceed that in non-ESAF developing countries due solely to lower initial income levels, if all other factors were equal.

Nevertheless, they suggest that about half of the rise in per capita GDP growth in the nontransition ESAF countries between the early 1980 s and the early 1990 s may be attributed to strengthened policies. Structural reform and financial consolidation-reduced fiscal deficits and, in a few countries, lower inflation - both contributed to this result (Figure 16). When compared with other developing countries over the same period, ESAF countries' generally more successful efforts at macroeconomic stabilization were an important element behind the convergence in per capita growth rates between the two groups. Human capital accumulation (proxied by increases in life expectancy) and reduced population growth also figured prominently in the gains in growth among developing countries since the early 1980 s, in ESAF and non-ESAF countries alike.

The empirical model sheds some light on why average growth among ESAF users in Africa in particular has continued to lag behind that in other countries, notwithstanding some narrowing of the gap over time. Continuing weaknesses in structural policies are part of the story, as is apparent from Figure 16. However, using non-ESAF developing countries as a benchmark for comparison, it appears that by the early 1990 s, the dominant factors holding back relative growth performance in Africa were Figure 17. Balance of Payments
Developments

(Sample medians)

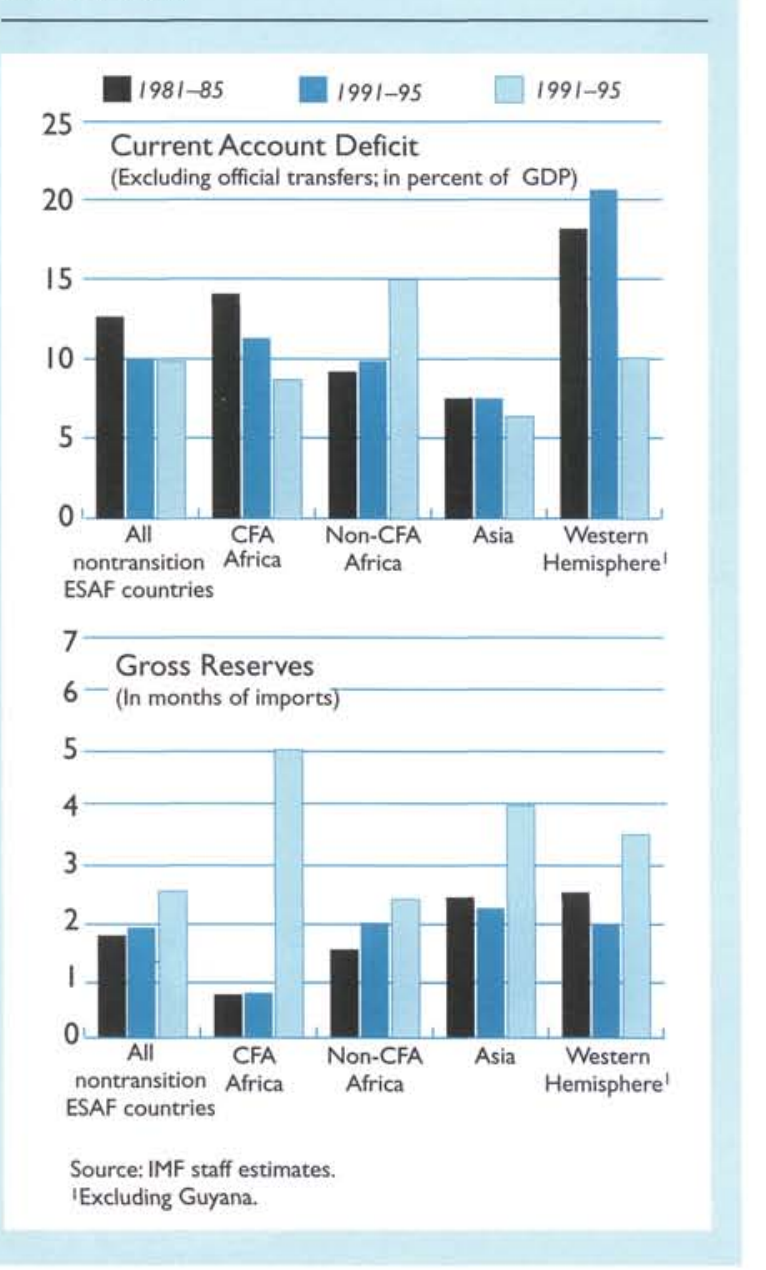

more rapid population growth and inadequate investment in human capital (Table 3). ${ }^{27}$ These impediments more than offset the growth advantage that African ESAF countries are estimated to have solely by virtue of their lower initial level of development (labeled "catch-up" in Table 3). These findings, which are consistent with those of other studies, highlight the importance of policies aimed at raising health and education standards in these countries. At the same time, given that the impact of such policies will be felt only gradually, this analysis brings into

\footnotetext{
${ }^{27}$ Although the latter is proxied in the equation for growth by life expectancy, it can be interpreted as encompassing general standards of health and education. Empirical studies of growth commonly find an important influence from primary and secondary education levels.
} 
Table 4. External Debt: Some Long-Run Comparisons

(In percent unless otherwise indicated)

\begin{tabular}{|c|c|c|c|c|c|c|}
\hline & \multicolumn{2}{|c|}{ ESAF Users ${ }^{1}$} & \multicolumn{2}{|c|}{ Low-Income Countries } & \multicolumn{2}{|c|}{ All Developing Countries ${ }^{2}$} \\
\hline & 1985 & 1995 & 1985 & 1995 & 1985 & 1995 \\
\hline \multicolumn{7}{|l|}{ Total external debt } \\
\hline In billions of U.S. dollars & 81.6 & 161.0 & 198.3 & 534.8 & $1,028.3$ & $2,065.7$ \\
\hline In percent of GNP & 71.1 & 87.8 & 24.7 & 38.7 & 34.0 & 39.6 \\
\hline Share of public and publicly guaranteed debt & 77.1 & 82.2 & 74.7 & 81.9 & 71.0 & 70.1 \\
\hline \multicolumn{7}{|l|}{ Of which, shares held by: } \\
\hline Bilateral creditors & 48.8 & 43.6 & 44.0 & 42.9 & 28.8 & 39.1 \\
\hline Multilaterals (excluding IMF) & 20.2 & 44.1 & 17.3 & 27.8 & 9.0 & 16.1 \\
\hline IMF & 10.1 & 5.8 & 9.9 & 3.3 & 5.3 & 4.2 \\
\hline Private creditors & 20.9 & 6.5 & 28.8 & 26.0 & 56.9 & 40.6 \\
\hline Concessional debt as share of total ${ }^{3}$ & 47.2 & 65.9 & 39.4 & 42.0 & 16.6 & 21.1 \\
\hline Average grant element in new borrowing ${ }^{4}$ & 50.0 & 61.7 & 29.9 & 29.6 & 15.1 & 20.2 \\
\hline \multirow{2}{*}{\multicolumn{7}{|c|}{$\begin{array}{l}\text { Sources: World Bank, Debtor Reporting System; and IMF staff calculations. } \\
\text { 'Excluding transition economies. }\end{array}$}} \\
\hline & & & & & & \\
\hline \multicolumn{7}{|l|}{${ }^{2}$ World Bank definition, including ESAF countries. } \\
\hline \multicolumn{7}{|c|}{${ }^{3}$ Loans with an original grant element of at least 25 percent. } \\
\hline
\end{tabular}

stark relief the challenge facing African countries if they are to narrow the gap in per capita income levels vis-à-vis the rest of the world.

\section{External Viability}

The relatively poor response of saving rates to rising growth and improved policies in ESAF countries has meant that current account deficits were barely reduced, on average, over the past decade (Figure 17). Consequently, the stock of ESAF users' external debt-about 80 percent of which is public or publicly guaranteed - almost doubled between 1985 and 1995.28 By comparison with prior history, a much larger portion of this debt was provided on concessional terms by multilateral creditors, while private creditors substantially reduced their exposure to ESAF countries (Table 4).

Data on overall external financing flows, although sketchy, suggest that ESAF countries in non-CFA Africa and the Western Hemisphere were the principal beneficiaries of official flows-both transfers and loans - over the past 10 years (Table 5). Relative to the size of their economies, total financing flows to countries in these regions increased markedly between the early 1980 s and early 1990 s, with a rising proportion in the form of official transfers. By con-

\footnotetext{
${ }^{28}$ This increase is less than the debt buildup experienced by all low-income countries over the same period ( 170 percent), but is similar to the average for developing countries as a whole.
}

trast, Asian and CFA countries obtained stable or declining amounts of external financing (relative to their GDP) and relied much less heavily than the other regions on debt relief and arrears as a source of funds. Except in Asia and the transition economies, private capital flows, although rising in recent years, remained small in relation to total financing needs. ESAF users in all regions achieved a substantial increase in official reserve coverage, particularly during the early 1990s (Figure 17).

These tendencies were to a large extent already apparent at the time of the previous ESAF review. That review concluded that only about half of the then 19 ESAF users had succeeded in making progress toward external viability (see Box 5 on definitional issues), although almost all had halted the trend deterioration in their external debt situations. In Tsikata (forthcoming), this analysis is brought up to date and extended to the now larger sample of countries. Possible factors underlying relative progress across countries are also considered, albeit in rather broad terms, given that this will be the subject of a detailed study in the external evaluation of the ESAF (see above).

As in the last review, the present study gauges progress toward external viability primarily on the basis of indicators of the debt burden and the degree of reliance on exceptional financing, with some reference also to indicators of "external vulnerability." However, the emphasis here is shifted away from measures based on debt stocks. Nominal debt stock ratios give a misleading picture when average repayment terms become increasingly concessional, as they 
Table 5. Net External Flows to ESAF Countries

(Annual averages; in percent of GDP)

\begin{tabular}{|c|c|c|c|}
\hline & $1981-85$ & $1986-90$ & $1991-95$ \\
\hline \multicolumn{4}{|l|}{ Non-CFA Africa } \\
\hline Official transfers & 5.0 & 7.7 & 10.2 \\
\hline Net flows on long-term debt ${ }^{\prime}$ & 4.7 & 5.9 & 5.0 \\
\hline Debt relief and arrears ${ }^{2}$ & 2.7 & 4.0 & 5.5 \\
\hline Net foreign investment ${ }^{3}$ & 2.0 & 2.7 & 11.2 \\
\hline Net credit from IMF & 0.4 & 0.1 & 0.2 \\
\hline \multicolumn{4}{|l|}{ CFA Africa ${ }^{4}$} \\
\hline Official transfers & 7.0 & 6.9 & 6.3 \\
\hline Net flows on long-term debt ${ }^{1}$ & 6.5 & 4.3 & 2.8 \\
\hline Debt relief and arrears ${ }^{2}$ & 2.9 & 4.2 & 4.4 \\
\hline Net foreign investment ${ }^{3}$ & 3.2 & 2.6 & 1.5 \\
\hline Net credit from IMF & 0.9 & -0.2 & 0.3 \\
\hline \multicolumn{4}{|l|}{ Asia (nontransition) } \\
\hline Official transfers & 3.1 & 2.3 & 1.7 \\
\hline Net flows on long-term debt ${ }^{\prime}$ & 3.7 & 3.6 & 2.5 \\
\hline Debt relief and arrears ${ }^{2}$ & 0.1 & 0.0 & 0.0 \\
\hline Net foreign investment ${ }^{3}$ & 2.7 & 2.6 & 7.4 \\
\hline Net credit from IMF & 0.2 & 0.0 & 0.1 \\
\hline \multicolumn{4}{|l|}{ Western Hemisphere ${ }^{5}$} \\
\hline Official transfers & 2.0 & 6.0 & 8.1 \\
\hline Net flows on long-term debt ${ }^{\prime}$ & 6.9 & 14.1 & 5.0 \\
\hline Debt relief and arrears ${ }^{2}$ & 7.5 & 9.8 & 19.2 \\
\hline Net foreign investment ${ }^{3}$ & 1.9 & 3.9 & 13.0 \\
\hline Net credit from IMF & 0.2 & 0.1 & 0.5 \\
\hline \multicolumn{4}{|l|}{ Transition economies } \\
\hline Official transfers & & & 8.6 \\
\hline Net flows on long-term debt' & & & 3.6 \\
\hline Debt relief and arrears ${ }^{2}$ & & & 1.3 \\
\hline Net foreign investment ${ }^{3}$ & & & 19.4 \\
\hline Net credit from IMF & & & 0.9 \\
\hline \multicolumn{4}{|c|}{$\begin{array}{l}\text { Sources: IMF staff estimates; and World Bank, Debtor Reporting System. } \\
\text { 'Excluding borrowing from the IMF. }\end{array}$} \\
\hline \multicolumn{4}{|c|}{ 2Rescheduling, change in arrears and debt cancellation. } \\
\hline \multicolumn{4}{|c|}{${ }^{3}$ Net foreign direct investment and portfolio equity flows. } \\
\hline \multicolumn{4}{|l|}{${ }^{4}$ Excluding Equatorial Guinea. } \\
\hline${ }^{5}$ Excluding Guyana. & & & \\
\hline
\end{tabular}

have done for ESAF countries since the mid-1980s (see Table 4); and historic time series for debt in present value terms are not available. Instead, two measures of the debt-service burden are consideredspecifically, the ratio to exports (an indicator of the "foreign exchange" burden of debt) and the ratio to GDP (an indicator of the "internal transfer" burden). ${ }^{29}$

\footnotetext{
${ }^{29}$ The internal transfer burden is sometimes alternatively referred to, in countries where the bulk of external debt is public, as the "fiscal" burden, and measured in relation to fiscal revenues. The debt-service-to-revenue ratio may, however, understate the debt burden when government revenues are unsustainably high as a share of GDP; conversely, when the fiscal system is in disarray and revenues are "too low," it can misidentify as a debt problem
}

In relation to exports of goods and services, scheduled debt service has been on a fairly consistent downward trend for the average nontransition ESAF country since the mid-1980s, from a median of 40-45 percent then, to about 28 percent in 1995 (Figure 18). For the ESAF users classified as heavily indebted poor countries (HIPCs), the decline has been similar but at a level about 5 points higher. ${ }^{30}$

what is more properly viewed as a problem of fiscal administration. Using the ratio of debt service to GDP is a way of avoiding this potential difficulty.

${ }^{30}$ Note that the coverage of the HIPC group in Figure 16 excludes transition economies and Tanzania, owing to problems of data availability and reliability. 
There is, however, no discernible trend over the long run in measures of the "internal" burden of foreign debt: average scheduled debt service stayed within ranges of 4-5 percent of GDP (8-9 percent for HIPCs) for most of the last 10 years. This disparity between the external and internal perspectives on the debt burden is a reflection of the marked rise in the share of exports in ESAF countries' GDP.

Focusing on individual country experiences since the pre-SAF/ESAF period, out of 27 countries where data permit an assessment, 12 can be said to have made "clear" progress toward external viabilitydefined as an improvement (or maintenance at low levels) in all three of the principal indicators: the ratios of debt service to exports and GDP and the ratio of exceptional financing to exports (see Table 6 for country coverage and exclusions). In another 10 countries, "limited" progress was achieved, meaning that no more than one of the indicators showed a deterioration since the pre-SAF/ESAF period. In all but 2 of these 10 cases, the ratios of debt service to exports and GDP both improved, and only reliance on exceptional financing failed to move in the desired direction (see Table 6).

Thus, 22 out of 27 countries appeared to have made some measure of progress toward external viability. Bearing in mind that changes in methodology make comparisons difficult, this suggests some improvement on the findings of the last ESAF review, where only half of the countries were considered to have advanced in relation to the external objective. It remains true, however, that many of the countries that progressed continue to have heavy debt burdens: 13 out of the 22 had scheduled debt service in excess of 25 percent of exports in 1995. Looking at two measures of external vulnerability-export diversification and reserve coverage-13 of the 22 countries appear to have strengthened their position over the last 10 years, with neither indicator worsening and at least one improving (see Table 6). ${ }^{31}$

At the other end of the spectrum are five countries (Honduras, Kenya, Madagascar, Sierra Leone, and Zimbabwe) where no apparent progress was made toward external viability during the period under review. ${ }^{32}$ What explains the disappointing results in these cases, by comparison with the more successful ones? Several hypotheses were examined.

\footnotetext{
${ }^{31}$ Countries that may have weakened in this respect are Malawi, Mauritania, Senegal, and Togo; for others, the direction of change is unclear.

${ }^{32}$ Failure to make progress does not necessarily mean that these countries now face an unsustainable debt situation: for example, Kenya (a HIPC) and Zimbabwe (a non-HIPC) have had relatively moderate debt burdens throughout the period since their SAF/ESAF-supported adjustment efforts began. More generally, debt sustainability must be assessed on a forward-looking basis.
}

\section{Box 5. Defining Progress Toward External Viability}

At the time the ESAF was established, it was stipulated that members undertaking ESAF-supported programs should attain-or at least approach - a situation by the end of a three-year arrangement in which the external current account deficit can be financed by "normal" and "sustainable" capital inflows. Abnormal or exceptional financing for these purposes includes arrears accumulation, debt rescheduling or cancellation, and official balance of payments support. Sustainable inflows were defined as those that would not jeopardize the country's external debt or debt-service position. Thus, declining reliance on exceptional financing and improving debt burden indicators would be taken as evidence of progress toward external viability. (One limitation of the exceptional financing indicator is that it treats all forms of such financing as equivalent: it fails in particular to distinguish between agreed debt relief and disorderly accumulation of arrears.)

Underlying the recent Initiative for heavily indebted poor countries (HIPCs) is the related concept of "debt sustainability." This too requires a move toward orderly relations with creditors, in the sense of graduation from arrears and debt rescheduling as sources of finance. It also focuses on debt burden indicators, requiring that they be brought within or below specified manageable ranges. Unlike the notion of external viability, however, debt sustainability does not necessarily require that official balance of payments support be eliminated in the medium term, although program projections would be expected to show a reduced reliance on such support and an eventual exit from the need for ESAF arrangements.

Thus, progress toward external viability also in effect represents progress toward debt sustainability.

- First, that those making more progress might have obtained more favorable borrowing terms. This is not supported by the data. The average grant element in new borrowing incurred since a country's first SAF/ESAF-supported program was 63 percent for those that made "clear" progress toward external viability, 67 percent for countries achieving "limited" progress, and 54 percent for the "no" progress group. These differences are not statistically significant.

- Second, that the most successful might have received higher official transfers. While the scale of official transfers has varied widely across countries, it appears that the groups making progress toward viability did receive more transfers on average than those that did not: in 
Figure 18. Alternative Measures of the Debt-Service Burden (Sample medians)

All ESAF Countries
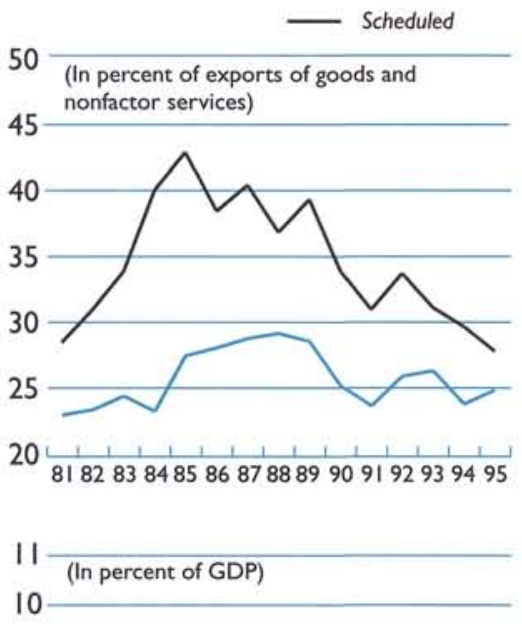

9

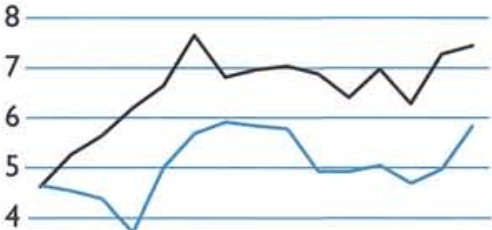

3 $\frac{1}{81} 8283848586878889909192939495$

\section{ESAF HIPCs 1}
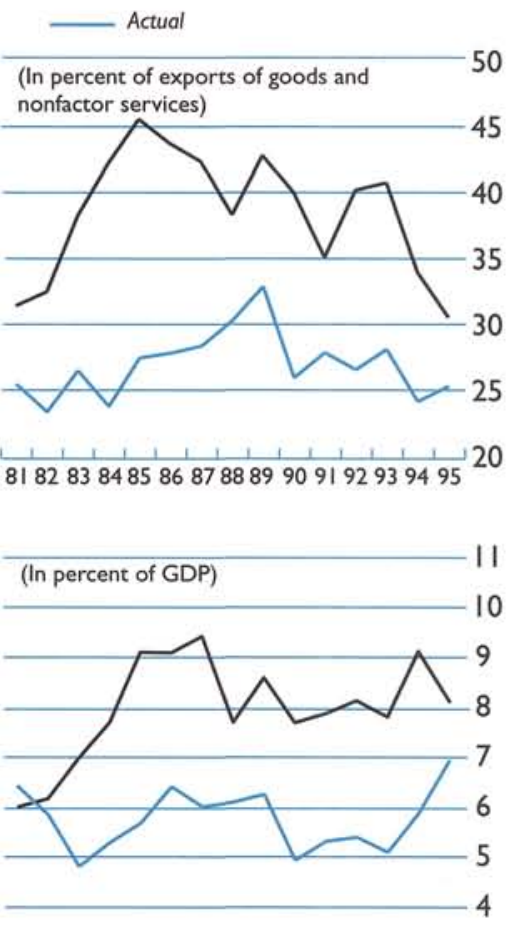

8182838485868788899091929394953

Source: IMF staff estimates.

'Excluding transition economies, The Gambia, Tanzania, and Guyana (bottom panels only).

relation to the initial (pre-SAF/ESAF) debt stock, such transfers averaged 12 percent a year in the "clear" and "limited" progress groups, and $4 \frac{1}{2}$ percent a year in the "no" progress group. These differences may be linked to comparative policy performance. ${ }^{33}$

- Third, that maintaining smaller current account deficits might have been a determining factor. In fact, the reverse appears to be true: measuring current account deficits in relation to initial-

\footnotetext{
${ }^{33}$ Two pieces of evidence can be offered on this point: first, since beginning SAF/ESAF-supported adjustment, the proportion of years in which annual programs were completed was much less (about 35 percent) for the "no" progress group than for the other groups combined (about 55 percent); and second, the "no" progress group achieved significantly less fiscal adjustment than the "clear" progress group over the same period (see Figure 19).
}

period debt stocks, the averages are 20 percent for the "clear" progress group, 16 percent for the "limited" progress cases, and 7 percent for the countries making "no" progress.

- Fourth, that countries making most progress may be those achieving higher rates of economic growth, particularly in favor of exports, and hence more rapid expansion in the resource base available to support external debt. This appears to be the critical factor. Since the preSAF/ESAF period, real GDP and export volumes have grown at annual rates 3-6 percentage points faster, on average, among countries making "clear" progress toward viability than among "no" progress countries (Figure 19).

Thus, far from being conflicting objectives, it appears that strong (export-led) growth and greater progress toward external viability are complemen- 
Table 6. Indicators of Progress Toward External Viability' (In percent unless otherwise indicated)

\begin{tabular}{|c|c|c|c|c|c|}
\hline \multicolumn{2}{|c|}{ Scheduled Debt Service in Relation to } & \multirow{2}{*}{$\begin{array}{c}\text { Exceptional } \\
\text { Financing Ratio }{ }^{4}\end{array}$} & \multirow{2}{*}{\multicolumn{2}{|c|}{ Export Concentration ${ }^{5}$}} & \multirow[b]{2}{*}{ Reserve Coverage $^{6}$} \\
\hline Exports ${ }^{2}$ & GDP & & & & \\
\hline & Pre- & & & & \\
\hline ESAF $^{3} \quad 1993-95$ & ESAF $^{3} \quad 1993-95$ & ESAF $^{3} \quad 1993-95$ & changed & Rose & Rose changed Fell \\
\hline
\end{tabular}

\begin{tabular}{|c|c|c|c|c|c|c|c|c|c|c|c|c|}
\hline \multicolumn{13}{|l|}{ Clear progress ${ }^{7}$} \\
\hline Bangladesh & 30.3 & 12.8 & 2.1 & 1.3 & 0.0 & 0.0 & & $\cdot$ & & $\cdot$ & & \\
\hline Benin & 48.6 & 30.1 & 6.0 & 4.6 & 40.7 & 13.0 & & & $\cdot$ & - & & \\
\hline Bolivia & 80.0 & 39.4 & 12.2 & 7.6 & 46.4 & 14.9 & • & & & & - & \\
\hline Burkina Faso & 29.0 & 21.9 & 3.2 & 2.8 & 11.2 & 2.3 & & & $\cdot$ & $\cdot$ & & \\
\hline Gambia, The & 44.9 & 25.7 & 7.2 & 4.5 & 38.0 & -0.3 & $\cdot$ & & & $\cdot$ & & \\
\hline Lesotho & 41.0 & 14.9 & 3.5 & 2.8 & 0.0 & 0.0 & $\cdot$ & & & $\cdot$ & & \\
\hline Malawi & 47.5 & 27.8 & 13.6 & 10.8 & 5.5 & -2.4 & & $\cdot$ & & & & - \\
\hline Mauritania & 34.5 & 32.7 & 17.5 & 15.1 & 13.3 & 7.6 & & $\cdot$ & & & & - \\
\hline Nepal & 6.7 & 10.7 & 0.7 & 1.6 & 0.0 & 0.0 & & & $\cdot$ & $\cdot$ & & \\
\hline Pakistan & 35.8 & 27.6 & 4.5 & 4.5 & 0.4 & 0.0 & $\cdot$ & & & $\cdot$ & & \\
\hline Sri Lanka & 21.3 & 12.5 & 5.5 & 4.3 & 0.0 & 0.0 & & & $\cdot$ & $\cdot$ & & \\
\hline Uganda & 67.8 & 38.5 & 4.8 & 4.2 & 5.2 & 0.9 & $\cdot$ & & & $\cdot$ & & \\
\hline Mean & 40.6 & 24.5 & 6.7 & 5.4 & 13.4 & 3.0 & & & & & & \\
\hline \multicolumn{13}{|l|}{ Limited progress ${ }^{7}$} \\
\hline Burundi & 49.9 & 34.3 & 4.9 & 4.0 & 0.0 & 2.3 & & • & & $\cdot$ & & \\
\hline Equatorial Guinea & 59.6 & 35.2 & 18.8 & 16.3 & -34.1 & 28.4 & $\cdot$ & & & & - & \\
\hline Ghana & 45.3 & 27.1 & 5.0 & 6.4 & -14.3 & -0.7 & & $\cdot$ & & - & & \\
\hline Guinea & 32.9 & 29.6 & 9.7 & 6.2 & 3.6 & 14.7 & $\cdot$ & & & - & & \\
\hline Guyana & 96.8 & 27.7 & & & 4.5 & 8.0 & $\cdot$ & & & - & & \\
\hline Mali & 42.0 & 37.4 & 7.5 & 7.4 & 20.3 & 20.7 & & & - & - & & \\
\hline Mozambique & 291.7 & 136.4 & 13.3 & 33.1 & 278.2 & 197.1 & & $\cdot$ & & $\cdot$ & & \\
\hline Niger & 44.7 & 32.7 & 9.6 & 4.9 & 14.9 & 23.0 & $\cdot$ & & & $\cdot$ & & \\
\hline Senegal & 24.7 & 22.9 & 7.2 & 6.1 & 11.0 & 16.4 & & & $\cdot$ & & - & \\
\hline Togo & 44.5 & 39.6 & 14.8 & 9.0 & 13.3 & 34.3 & & & $\cdot$ & & & - \\
\hline Mean & 73.2 & 42.3 & 10.1 & 10.4 & 29.7 & 34.4 & & & & & & \\
\hline \multicolumn{13}{|l|}{ No progress ${ }^{7}$} \\
\hline Honduras & 37.6 & 38.1 & 11.0 & 13.1 & 13.5 & 7.3 & $\cdot$ & & & $\cdot$ & & \\
\hline Kenya & 25.7 & 29.2 & 5.6 & 8.8 & 0.0 & 1.0 & • & & & & & - \\
\hline Madagascar & 79.3 & 63.7 & 11.1 & 12.7 & 47.5 & 51.3 & $\cdot$ & & & & - & \\
\hline Sierra Leone & 51.6 & 59.0 & 5.5 & 9.3 & 21.3 & 39.8 & & & $\cdot$ & $\cdot$ & & \\
\hline Zimbabwe & 20.7 & 24.6 & 6.3 & 9.5 & 0.0 & 0.0 & & $\cdot$ & & $\cdot$ & & \\
\hline Mean & 43.0 & 42.9 & 7.3 & 10.2 & 20.0 & 17.8 & & & & & & \\
\hline
\end{tabular}

\footnotetext{
Source: IMF staff estimates.
}

'Excluding transition economies. Côte d'Ivoire and Nicaragua are excluded because their ESAF programs had been in place for less than three years at end-1995, and Tanzania because of severe deficiencies in official export data.

'Exports of goods and nonfactor services. For Lesotho, the denominator includes workers' remittances because of the dominance of this item in the country's foreign exchange earnings.

${ }^{3}$ Annual average for three years preceding first SAF/ESAF program.

${ }^{4}$ The sum of net change in arrears, rescheduling, and debt cancellation, as a ratio to exports of goods and nonfactor services.

${ }^{5}$ Change between 1985 and 1995 in share of total exports accounted for by the largest three export products.

${ }^{6}$ Change between 1985 and 1995 in official reserves, in months of imports. The indications for individual CFA countries (Benin, Burkina Faso, Côte d'Ivoire, Equatorial Guinea, Mali, Niger, Senegal, and Togo) are not as meaningful as for the other countries because of the pooling arrangements in the CFA.

${ }^{7}$ Countries that made "clear progress" are those that showed improvement in all three indicators, or (in the case of Nepal) that maintained indicators at low levels. Countries that made "no progress" are those where at least two indicators worsened. Countries with a mixed record are designated "limited progress." 


\section{Figure 19. Growth of Export Volume and of Real GDP, and Change in Fiscal Balance During the SAF/ESAF Period'}

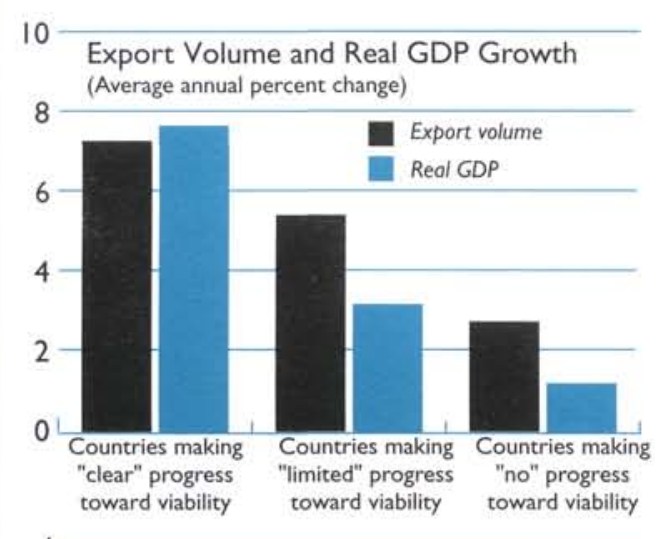

4 Cumulative Change in the Fiscal Balance ${ }^{2}$ (Sample medians, percentage points of GDP)

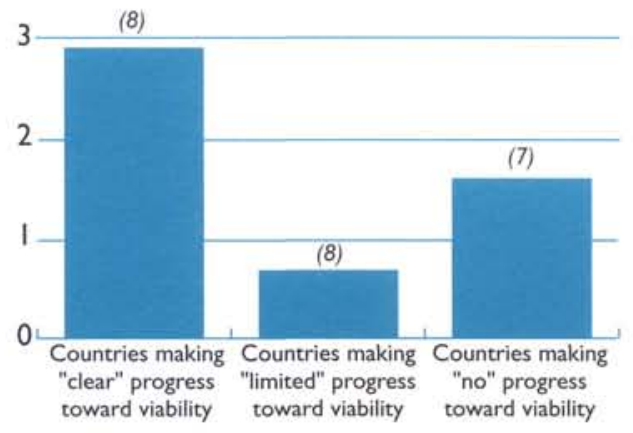

Source: Tsikata(forthcoming).

IFrom the year preceding the first SAF/ESAF arrangement to 1995; numbers in parentheses in the bottom panel indicate the average number of years for each group.

${ }^{2}$ Excluding grants. tary. ${ }^{34}$ This raises the question, however, of why debt management policies did not succeed in all countries in keeping debt accumulation in close correspondence with the evolving path of exports and output. If they had, even the slower-growing economies could have avoided a deterioration in

\footnotetext{
${ }^{34}$ Tsikata (forthcoming) reports additional evidence in support of this observation. It is shown there that progress toward external viability is not associated with import compression: as noted above, those making most progress toward this goal had, on average, the highest annual rate of import growth.
}

their external debt situation. Did countries borrow more than anticipated in SAF/ESAF-supported programs? Were borrowing plans based on overoptimistic assumptions-for instance, regarding export growth? Or was it that large amounts of debt were accumulated outside the context of programs (that is, either between programs or when programs had broken down)?

The evidence suggests that the problem does not appear to be one of widespread overshooting of borrowing plans. Among a sample of those that had made "limited" or "no" progress toward external viability, formal program limits on external borrowing (which apply only to nonconcessional borrowing) were found to have been almost universally respected. ${ }^{35}$ Likewise, projections of overall official borrowing were met or undershot in more than three-quarters of the cases examined. Nor is there evidence of systematic overprediction of exports, if one controls for broad policy implementation: there is a slight (but statistically significant) pattern of overprediction on a full sample, but within the set of programs completed without interruption, exports were as likely to exceed as to fall short of target. ${ }^{36}$

What is less clear is that borrowing is curtailed significantly when policy implementation falters. The proportion of programs where official borrowing projections were undershot was no higher among interrupted programs than among programs that were completed without interruption. In a similar vein, the average rate of increase in the debt stock during program interruptions (at 7.7 percent a year) was slightly higher than in years when programs were on track ( 7.4 percent a year). Half of the 14 countries examined were borrowing at a faster pace during interruptions than during "on track" years. ${ }^{37}$ Thus, one likely explanation for lack of progress toward external viability, in cases where it occurred, is that export growth (and perhaps economic activity more generally) suffered more than the country's access to external financing when policies weakened.

\footnotetext{
${ }^{35}$ Such targets were found to be quite stringent, often disallowing new nonconcessional borrowing altogether, though their coverage was limited (inter alia due to the exclusion of long maturities).

${ }^{36} \mathrm{An}$ "uninterrupted program" is defined as one where the supporting arrangement ran its full course and where delays (if any) in completing reviews did not exceed six months (see the section on "Sustaining Programs").

${ }^{37}$ These 14 cases were those that had, at some point, experienced program interruptions of at least a year.
} 


\section{Lessons for Program Design}

C ountries undertaking programs of adjustment and reform supported by the SAF and ESAF have brought their economies a long way from the doldrums of the early 1980s. Real per capita output growth among nontransition ESAF users has, on average, caught up with that in other developing countries. The social indicators in most countries have improved. Roughly three-quarters of ESAF users have moved closer to external viability. Budget deficits have been trimmed, and instances of very high inflation have been virtually eliminated. Developments in the last one to two years have been even more encouraging: while this may owe something to the favorable global environment, the liberalization and restructuring undertaken over the past decade give grounds for believing that durable gains in economic potential have been achieved in the countries under review.

Notwithstanding these gains, ESAF countries remain among the poorest in the world, and must aim for faster economic growth than other developing countries on a sustained basis if they are to close the enormous gap in living standards. ${ }^{38}$ This is not in prospect so long as their investment and domestic saving rates continue to fall short of those in the rest of the developing world. Bolder strategies are called for to lift countries onto a higher growth path. This review has confirmed that the achievement of sustained, outward-oriented growth is also critical in accelerating progress toward external viability. Hence, the two principal goals of the ESAF are mutually supporting and can be achieved through a common set of policies, combined with access to financing on appropriate terms and debt relief where necessary.

At the heart of a strengthened approach must be greater efforts to cut government budget deficits, which in 1995 still averaged 7-8 percent of GDP (overall, before grants) in the countries under review. Numerous empirical studies have concluded that public saving is the most-possibly the only-

\footnotetext{
${ }^{38} \mathrm{As}$ is well established in the literature, GDP growth is highly correlated with improved living standards and reductions in poverty (see Jayarajah and others (1996)).
}

effective policy instrument to influence national saving directly in the near term. ${ }^{39}$ This study finds that weak fiscal discipline inhibits growth through other channels as well - by contributing to chronic inflation, weak external positions, and stop-go policy implementation. With these interrelationships in mind, proposals for strengthening ESAF-supported programs have been grouped under four broad headings: (1) the key elements of a stronger and reoriented fiscal adjustment effort; (2) a more resolute approach to reducing inflation; (3) a more focused and concerted push on key structural reforms; and (4) steps to reduce the incidence of major policy slippages and encourage more sustained policy implementation. These proposals are discussed in turn.

\section{Growth-Enhancing Fiscal Adjustment}

By and large, fiscal adjustment thus far in ESAFsupported programs has been modest, and future programs should aim to bring about more decisive deficit reduction. For many countries, simply meeting targets more or less as ambitious as those set in the past would represent a major advance, while for others the objectives themselves should be more ambitious. The means to achieve the required additional adjustment, however, may also have important implications for economic growth, as well as for the path of adjustment itself. In many countries, the bulk of deficit reduction will have to come from structural reform on the expenditure side, in the civil service and public enterprises in particular. Since such reforms may be costly in the short term (requiring redundancy payments, for instance), it should not always be expected that budget deficits will be reduced in the first program year. A general aim, however, should be to cut deficits and raise national saving rates significantly over the course of a three-year pro-

\footnotetext{
${ }^{39}$ For a survey of this evidence, see Goldsbrough and others (1996). The main factor driving private saving appears to be the growth of income, implying that strategies to raise growth will indirectly stimulate private saving.
} 
gram. As programs are implemented, policies should be adjusted as necessary to ensure this result.

\section{The Tax Burden}

There are no established standards for what would constitute an "appropriate" tax burden in ESAF countries. Revenue objectives need to be related to some notion of the adequacy and efficiency of government spending and, more generally, the appropriate size of government. There is evidence, however, that the capacity to raise revenue efficiently tends to rise with the level of economic development. For ESAF countries, revenue-GDP ratios in excess of about 20 percent would be higher than expected, given their level of development. ${ }^{40}$ Accordingly, some ESAF countries with ratios much above this level should probably aim to reduce the revenue burden over time. Conversely, there are cases-notably those countries in which taxes amounted to less than 10 percent of GDP in 1995 - where higher revenues should be feasible, both as part of an additional fiscal adjustment effort and to support a higher level of productive government expenditure in the medium term.

For most ESAF users, however, the share of tax revenues in GDP is already comparable to that in other developing countries. This suggests that these countries should be focusing their tax reform efforts on simplifying and rationalizing tax systems to make revenues more robust and minimize distortions (Box 6), rather than to boost the overall tax take. In the process, resort to short-term ad hoc revenue measures-often made out of budgetary necessity — should be viewed as strictly temporary and not as a substitute for fundamental reform of tax policy and administration.

\section{Capital Spending}

Deficit reduction achieved through cuts in capital spending would not raise public saving. Whether capital spending in the public sector is too high or too low in ESAF countries is a difficult judgment and one that would need to be made case by case. But it seems clear that repeatedly squeezing capital spending ad hoc when revenues fall short of target, as has been common practice, is not the appropriate way for such important allocative decisions to be made. This problem could be addressed in program design by (1) incorporating in budgets more cautious assumptions regarding the feasible pace of tax reforms (or the response of revenues to reforms); and (2) putting highpriority capital spending in a "core" budget, to be protected against adverse contingencies.

\footnotetext{
${ }^{40}$ See Abed and others (forthcoming). The "level of develop-
} ment" is broadly equated here with per capita income levels.

\section{Box 6. Strengthening Tax Systems}

The review of tax policies in ESAF countries in Abed and others (forthcoming) suggests some important priorities for tax reform in future programs:

- First, a well-designed, broad-based consumption tax such as the VAT appears to be the surest instrument for achieving a rapid strengthening of the revenue base, in a way that minimizes disincentives to save and invest. It can also lay the groundwork for improving other taxes, such as those on international trade. The tax should have a single rate (or at most two rates) and the fewest possible exemptions.

- Second, as domestic tax reforms take effect, import tariffs should be reduced to moderate or low average rates, and the dispersion narrowed so as to reduce arbitrary and excessive rates of effective protection. Export duties should be avoided.

- Third, reforms of taxes on incomes and profits should focus on simplification and base broadening, to allow needed reductions in overly high marginal tax rates. These reforms should usually be complemented by a simplified (generally presumptive) tax regime for small businesses and the informal sector.

- Fourth, significant gains in revenue performance are attainable from improvements in tax and customs administration, such as streamlined procedures, special attention to large taxpayers, improved audits, and computerization. Such reforms have long gestation lags, however, and need to be started early and sequenced carefully if they are to pay dividends during a program period.

\section{Social Spending}

Spending on health and education, though conventionally classified as government consumption, is more in the nature of investment (in human capital). Provided the resources are used effectively, such spending is growth enhancing. Like productive capital spending, therefore, high-priority expenditures on health and education should be protected in a "core" budget. ${ }^{41}$ To ensure this, considerable improvements are needed in the quality and availability of expenditure data on a functional basis, together with information on the efficiency of such expenditure. This should be a focus of technical assistance and new donor financing. Such efforts would complement World Bank plans to enhance its monitoring of the "outputs" from social spending (school enrollment, literacy rates, access to safe water, and so on) and may lead to a better understanding of the links between input and output indicators.

\footnotetext{
${ }^{41}$ The reference to prioritization here is important: it would not necessarily be desirable to include, for instance, spending on university education or specialized curative health services in the core budget.
} 
Closer monitoring is also needed to allow effective evaluation of social safety net measures incollaboration with the World Bank and other institutions. While such measures now feature prominently in many ESAF-supported programs, little followup information has been provided regarding their impact on the targeted population groups.

\section{Other Current Spending}

This leaves three areas where progress to date has not been adequate and a clear break from the past is essential to bring about the needed reduction in budget deficits.

- Civil service wage bills. Attempted reforms in this area have been partial, prone to reversal, and frequently reliant on cuts in wages rather than staff numbers. Thus, the quality and efficiency goals essential for long-term savings have not been met. The design of these reforms lies within the World Bank's mandate, but conditionality in IMF programs should attach greater weight to the achievement of headcount reductions and reforms of the civil service wage structure that would produce durable-if not immediate-budget savings, while improving the efficiency of the civil service.

- Public enterprises. The opportunity costs imposed by public enterprises on the state budget are not limited to the recorded subsidies and transfers. They extend to tax breaks, quasi-fiscal assistance - through directed loans from state banks, for instance-and tax revenues that would accrue if the assets were put to more productive use. Budgetary concerns are thus one of several reasons to intensify public enterprise reform in ESAF-supported programs.

- Military spending. In line with the global trend, military spending tended to decline during ESAF-supported adjustment and is now estimated to absorb around 2 percent of GDP or less in approximately half of all ESAF countries. In a good number of countries, however, a much higher level of resources continues to be devoted to the military, suggesting the potential to achieve significant economies in this area. Such opportunities should be seized, as and when the social and political climate permits.

\section{Expenditure Management}

Finally, improved budgeting and expenditure control systems are needed, both to promote the desired expenditure restructuring and to allow closer adherence to overall fiscal targets. There is a strong advantage to addressing problems in this regard at an early stage. Programs could therefore make greater use of prior actions to encourage progress in a number of areas, including measures to provide appropriate incentives for officials charged with implementing the reforms, and to ensure transparency and accountability in expenditure management.

\section{More Decisive Disinflation}

Experience suggests strongly that those countries with inflation stuck in the intermediate range are sacrificing growth. Although the empirical estimates are inevitably imprecise, the present study and others have found that costs appear to mount once inflation exceeds single-digit levels. ${ }^{42}$ The analysis in this study suggests that the negative relationship (plotted in Figure 20) is significant even after controlling for supply shocks (such as weather and the terms of trade) and other determinants of economic growth; that it is proportional-so that reducing inflation from 30 percent to 10 percent may be just as beneficial as reducing it from 90 percent to 30 percent; and that it applies in ESAF countries just as in other developing countries. In contrast to some earlier findings (particularly those drawn from studies that impose a linear form on the inflation-growth relationship), these results seem to hold even when all cases of high inflation are excluded from the analysis.

The nature of this relationship is uncertain and probably complex: growth may benefit from low inflation directly, through improved resource allocation and higher investment, or indirectly as a result of the broad-based reforms that are typically needed to sustain low inflation. Thus, the full effects are likely to accrue only in response to an anti-inflation strategy that is comprehensive and consistent. Nevertheless, the potential gains from policies that achieve and maintain low inflation appear to be substantial, not only for output growth but also for the distribution of income: inflation tends to be a regressive tax, especially in low-income countries, where inflation hedges for the poor are scarce.

\section{Potential Costs of Disinflation}

Disinflation is traditionally considered to impose short-run output losses on the economy. This depends on the circumstances, however. There is evidence that costs are lower at higher initial levels of inflation: thus, those with most to gain in the long run-

\footnotetext{
${ }^{42}$ See Phillips (forthcoming) for a detailed review of the evidence on these points and on the other empirical findings and analytical issues referred to in this section. A similar conclusion was reached in "The Rise and Fall of Inflation-Lessons from the Postwar Experience" (see International Monetary Fund (1996), especially pages 116-22).
} 


\section{Figure 20. Association of Real Per Capita GDP Growth with Log Inflation}

(Mean values within groups ranked by inflation) ${ }^{2}$

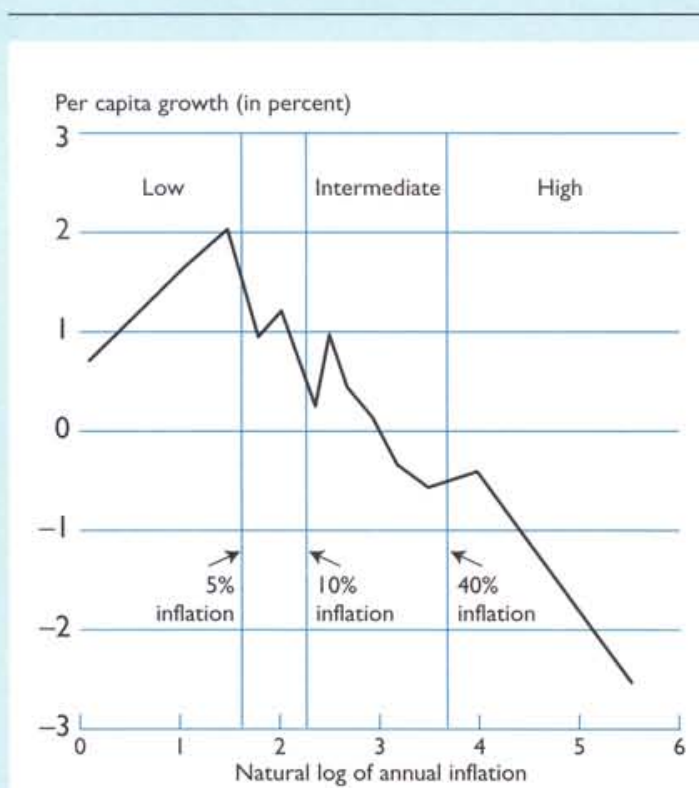

Source: IMF staff estimates.

'Based on 105 developing countries' annual data, 1981-95; a total of 1.564 observations ( 11 missing observations).

2The 1,564 observations were ordered according to rate of inflation, then divided into 15 subgroups of 104 observations each (the highest inflation group contains 108 observations).

those in or above the higher end of the intermediate inflation range - may also have least to lose in the short run. The degree of inflation inertia that generates the short-run losses is also likely to be less in ESAF countries, with typically large informal sectors, than in more developed economies. Finally, even if there is a short-run cost from the demand squeeze, this may be more than offset by accompanying supply-side effects when disinflation is part of a broader policy package supported by external financing (as is the case in ESAF-supported programs).

What is the evidence? Except in countries with low initial inflation (which have tended not to target disinflation), growth typically rose immediately in SAF/ESAF-supported programs (Figure 21). Looking closer at programs according to the degree of disinflation achieved, the record shows that even countries that halved their inflation rates in the course of a program had on average faster growth than during the preprogram period. This supports the notion that trade-offs between growth and inflation, if they exist, are dominated by other factors. It does not appear, then, that concerns about short-run out- put effects should deter countries from a bolder effort to reduce inflation; still less do they justify postponing disinflation indefinitely, as has happened in several cases.

Another consequence of disinflation is the need for the public sector to adjust to the loss of seigniorage, either by tapping other revenue sources or through expenditure savings. For countries with initial inflation in the 30-40 percent range (where seigniorage appears to be maximized), reaching 5-10 percent inflation could require the government to find compensating fiscal adjustments of as much as 2 percent to $2 \frac{1}{2}$ percent of GDP. This amount is sizable, but should be achievable if - as has been emphasized-low inflation is part of a strategy that would extend to fundamental tax and expenditure reform.

\section{Implications for Program Design}

SAF/ESAF-supported programs have in fact consistently targeted single-digit inflation. But the record in achieving this objective has, with few exceptions, been poor, both during and outside programs. The sharp downturn in inflation in 1996 in a number of countries is welcome, but-set against the trend of the previous 10 years-does not dispel concerns about program performance in this area.

Why have programs so often failed to deliver low inflation? One obvious answer would be that financial ceilings - in particular, on credit expansionhave not been respected. Overshooting of targets for net domestic assets (NDA) has indeed been common (Table 7). However, Phillips (forthcoming) finds no systematic link between adherence to program targets for NDA, on the one hand, and the record on meeting monetary growth and inflation targets on the other. Projected money growth was exceeded in 13 of the 14 programs where first-year NDA ceilings were met, reflecting unanticipated balance of payments inflows. ${ }^{43}$ Inflation overshot in 10 of these programs, and in fact did so even more frequently than when NDA ceilings were exceeded.

These findings point to two possible weaknesses in program design. First, programs may have underestimated the extent of fiscal adjustment needed to reach low inflation. The evidence does not show a clear relationship between inflation overshooting and deviations from fiscal targets in the programs under review. But the poor record on inflation calls strongly into question whether the fiscal targets

\footnotetext{
${ }^{43}$ The data are not adequate to identify the precise source of these inflows. As indicated in Table 7, they appear not to reflect unanticipated official borrowing. The bulk is recorded in the miscellaneous (residual) category "net private capital and balance of payments errors," the nature of which is highly uncertain.
} 
Figure 21. Real Per Capita GDP Growth in SAF/ESAF ProgramsI (Median; percent change over previous year)

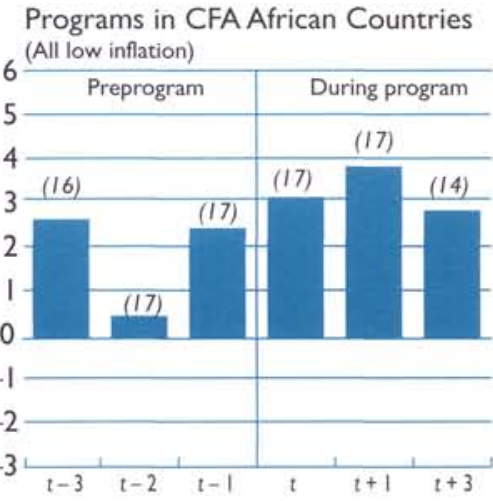

Other Programs with Low Initial Inflation

(Less than 10 percent)

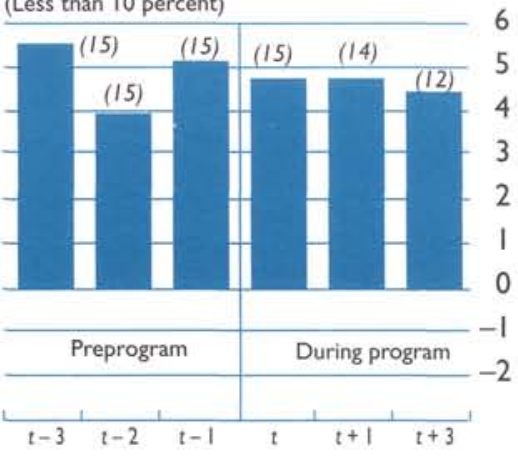

Programs with Intermediate Initial Inflation

(Between 10 and 40 percent)

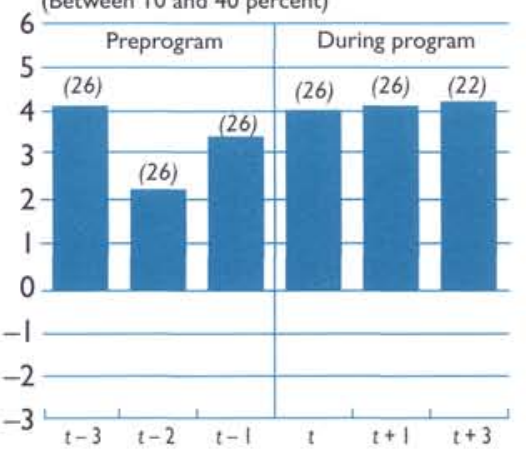

Programs with High Initial Inflation (Greater than 40 percent)

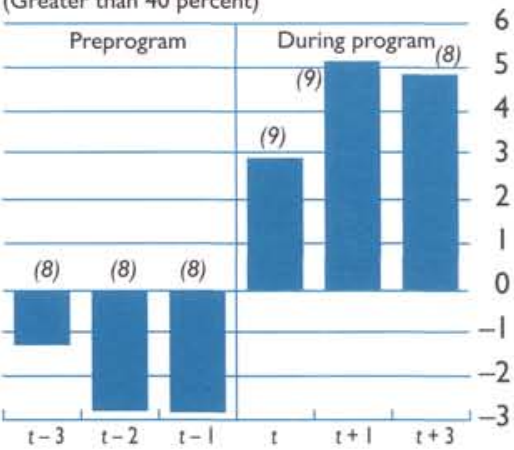

Source: Phillips (forthcoming).

IFigures in parentheses above bars refer to the number of observations (programs).

themselves were too loose to achieve the inflation objective, regardless of the stance of credit policy. It is striking that the stronger performers on inflation (countries that achieved average inflation of 10 percent or less during 1993-95) had reduced their primary fiscal deficits to less than one-third of the average level prevailing in other countries (Table 8). These findings add to the case for stronger fundamental fiscal reforms to achieve lower deficits on a sustainable basis.

Second, the large majority of programs lacked an effective nominal anchor, relying on NDA ceilings alone to enforce monetary discipline. To some degree, this may have reflected a recognition that the likely fiscal stance would be incompatible with a nominal anchor, particularly in light of concerns about competitiveness. However, unless supported by a commitment to a nominal exchange rate peg, or explicit inflation targets, NDA ceilings leave open a wide range of outcomes in which net foreign assets, money supply, and inflation may all exceed projections. ${ }^{44}$ Only 8 of the 35 SAF/ESAF-supported programs with intermediate or high initial inflation had a nominal anchor, in all but two cases an exchange rate peg. These programs delivered better-than-average inflation performance. By contrast, as many as one in five programs explicitly geared nominal ex-

\footnotetext{
${ }^{44}$ In principle, inflation control could be achieved with commitments to NDA ceilings and a pure floating regime for the exchange rate (no discretionary intervention in the foreign exchange market), since the latter insulates the economy from accommodating external flows. Few governments would commit to a pure float, however, and there is no example of such a regime among the countries under review. Chile provides an example of the successful use of preannounced inflation targets as a nominal anchor.
} 
Table 7. Deviations from Inflation Targets, by Net Domestic Assets Performance (Cases of intermediate and high initial inflation; first program year)

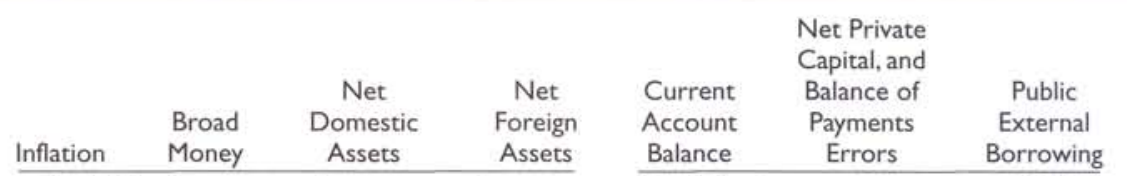

(Deviation from targeted percentage change)

(Deviation from target, as percent of GDP)

\begin{tabular}{|c|c|c|c|c|c|c|c|}
\hline \multicolumn{8}{|c|}{$\begin{array}{l}\text { Net domestic asset growth } \\
\text { limit respected (14 cases) }\end{array}$} \\
\hline Mean & 9.0 & 16.2 & -22.5 & 38.7 & 2.4 & 7.1 & -2.1 \\
\hline Median & 3.1 & 16.1 & -7.2 & 24.7 & 1.3 & 4.9 & -1.9 \\
\hline \multicolumn{8}{|l|}{$\begin{array}{l}\text { Of which: } \\
\text { Intermed } \\
\text { ( } 9 \text { case }\end{array}$} \\
\hline Mean & 11.7 & 11.9 & -22.9 & 34.9 & 0.5 & 3.8 & -0.1 \\
\hline Median & 6.0 & 6.2 & -7.4 & 17.2 & 0.5 & 5.2 & -1.7 \\
\hline \multicolumn{8}{|c|}{$\begin{array}{l}\text { Net domestic asset growth } \\
\text { limit exceeded ( } 21 \text { cases) }\end{array}$} \\
\hline Mean & 15.3 & 26.9 & 53.8 & -26.9 & 1.1 & 1.8 & -0.8 \\
\hline Median & 4.9 & 14.6 & 14.5 & -6.5 & 0.6 & 0.0 & -0.7 \\
\hline \multicolumn{8}{|c|}{$\begin{array}{l}\text { Of which: } \\
\text { Intermediate inflation } \\
\text { (17 cases) }\end{array}$} \\
\hline Mean & 4.4 & 13.1 & 30.4 & -17.3 & 1.0 & 2.8 & -0.2 \\
\hline Median & 4.4 & 13.6 & 9.5 & -5.4 & 1.3 & 0.2 & -0.6 \\
\hline
\end{tabular}

Source: IMF staff estimates.

change rate policy to a real exchange rate objective, and these had particularly poor inflation performance (Figure 22). 45

Programs should not continue to claim singledigit inflation as one of their intended results unless they are designed in such a way that, if the program is fully implemented, this outcome is reasonably assured. The programs under review did not, with hindsight, provide that assurance. Given the strong case for single-digit inflation as an objective, the preferred solution would be the adoption of a significantly bolder approach than has been common hitherto. The goal need not necessarily be rapid disinflation but, particularly when initial inflation is in the intermediate range, it should be expected that it would be brought down to single-digit levels in the course of a three-year program.

The centerpiece in such an approach would be a greatly strengthened fiscal position, underpinned by basic reform of the state finances (including those of the public enterprises). A sufficiently ambitious pro-

\footnotetext{
${ }^{45}$ The shortcomings of anchorless programs were examined at length in Schadler and others (1995a and 1995b).
}

gram of this kind-which includes an inflation goal-should achieve low inflation without formally committing to a nominal exchange rate target or a monetary anchor. But experience suggests that including a formal anchor in such circumstances could add to the program's credibility and may speed the transition to low inflation. A nominal exchange rate peg or, alternatively, performance criteria for reserve money would serve this purpose. Either one could be adopted on a temporary basis, until such time as low inflation had been established. Each has pros and cons. The exchange rate anchor is more transparent and may be more effective in altering inflation expectations, but it may also be more difficult to exit from smoothly. Money supply targets, on the other hand, do not require the backing of foreign reserves needed for an exchange rate peg and allow the exchange rate to adjust flexibly in response to shifts in the terms of trade; but they can be difficult to manage when the demand for money is highly uncertain (as it often is during disinflation). These factors would need to be weighed case by case.

There can be no doubt that the prerequisites for adopting a formal nominal anchor-staunch adherence to fiscal discipline and minimal indexation- 
Table 8. Financial Policies and Inflation Performance, 1993-95'

(Percent per annum, means)

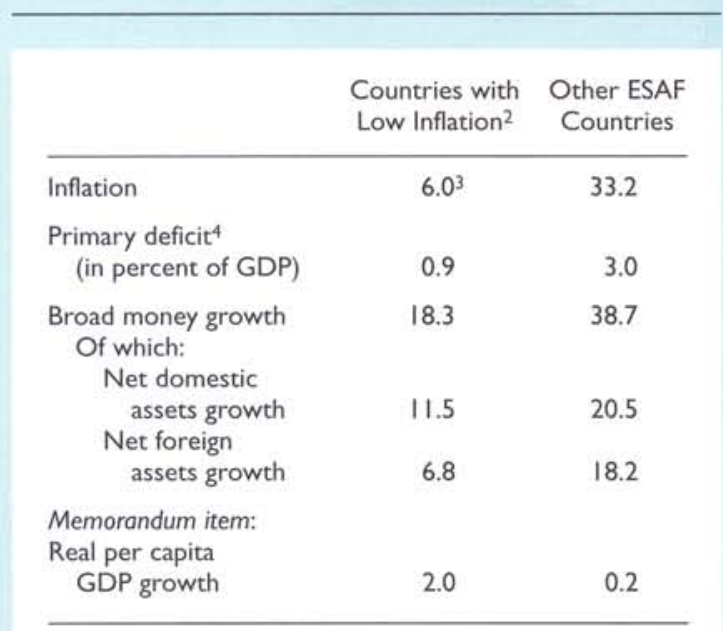

Source: IMF staff estimates.

'Excluding countries that did not begin their first SAF/ESAFsupported program until 1994 (Cambodia, Côte d'lvoire, Kyrgyz Republic, Nicaragua, and Vietnam).

${ }^{2}$ Those averaging single-digit inflation during 1993-95 (including Bolivia and Guyana, which averaged 10.1 percent and 10.6 percent inflation, respectively, in this period).

${ }^{3}$ Adjusted to exclude the 1994 outturns for the CFA countries, which were affected by the CFA franc devaluation in that year.

4Including grants. Excluding Guyana.

are exacting. There will therefore continue to be situations in which policies sufficiently strong to support a nominal anchor are judged to be beyond reach, at least in the near term. In these cases, programs should acknowledge that their ambitions, not only for inflation but probably also for growth, have to be correspondingly more modest. A more realistic assessment of inflation and growth prospects is needed to provide clearer guidance to national authorities on the additional adjustment needed to place their country on a higher growth trajectory.

\section{Advancing Structural Reforms}

Stronger macroeconomic adjustment would deliver a quicker and more pronounced supply response if accompanied by structural measures to encourage private investment and entrepreneurship. Most aspects of structural reform have some bearing on private sector development, and programs should continue to address structural weaknesses across a broad front, setting priorities on a case-by-case basis. Many ESAF countries have achieved a great
Figure 22. Inflation Performance With and Without Anchors I

(Sample medians; in percentage points)

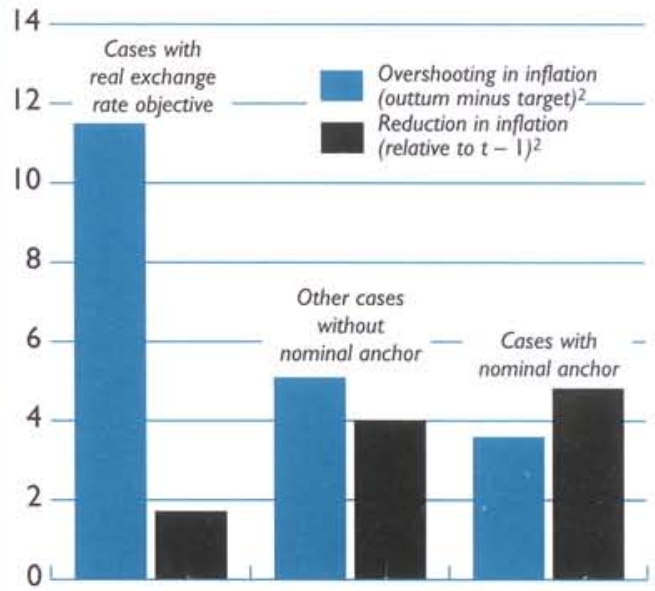

Source: Phillips (forthcoming).

IPrograms with intermediate initial inflation.

${ }^{2}$ Averages of $t$ to $t+2$, where $t$ is the first program year

deal already in areas such as the liberalization of prices and marketing and exchange system reform. Future programs should therefore be expected to devote increased attention to the "second generation" of reforms - those where progress has lagged, or where more can be done to raise countries' economic potential. These areas would include:

- Trade liberalization. There is increasing recognition of the important and wide-ranging benefits that result from opening economies to international trade and investment. The countries under review have made progress in this respect, but average tariff rates remain high and should be reduced and streamlined further, together with nontariff barriers.

- Public enterprise reform. Progress here has been limited, with the result that in most countries public enterprises continue to impede private sector development by preempting resources and hampering competition.

- Bank restructuring. Persistent weaknesses (operational and financial) in the banking sector are impairing efficient intermediation and thereby constraining business investment.

- Strengthened property rights. Clear and fair systems of property rights and adherence to the rule of law in business practices are prerequisites for a strong private sector. Many problems in this 
regard can be traced back to excessive regulation, complex tax and tariff structures, and direct state involvement in commercial affairs. At the same time, governments need to help ensure the development of well-functioning markets to finance private activities. Hence, the most effective contribution the IMF can make is to continue supporting programs that address these root causes, some of the most important of which lie in the first three areas identified above.

The slow pace of reform of public enterprises and banking systems was emphasized in the last ESAF review. The present study has therefore investigated-through detailed examination of selected country cases-the possible reasons for persistently slow progress in these two critical areas. The aim was to identify what could be done in the context of future ESAF-supported programs to help accelerate reform, recognizing that the World Bank retains the lead role in advising on the design and implementation of reforms in both areas. Hence, the focus here is on those aspects of policy - the linkages between structural reform and macroeconomic policies-that fall within the IMF's area of responsibility. The analysis and findings are set out in Decressin and others (forthcoming).

\section{Public Enterprise Reform}

The limited success in hardening the budget constraints of public enterprises in ESAF countries, and especially the disappointing results from performance contracts, have led to increasing emphasis in recent reform programs on privatization and less on state-managed restructuring. Privatization may indeed be the only way that inappropriate financial links between corporations and the government can be severed once and for all. The shift in this direction is therefore welcome, and should be further encouraged.

Nevertheless, because most ESAF users can be expected to retain some enterprises under state ownership, more must be done to ensure that essential discipline can be imposed effectively on these enterprises, and the potential threat they pose to financial stabilization contained. There is no realistic prospect of meeting this goal, however, without the compilation of adequate financial data on public enterprises. Although this issue has long been highlighted by the IMF, little has been done in the context of ESAF-supported programs to press for data improvements in this area. Of the five country case studies examined (involving 18 annual SAF/ESAFsupported programs among them), only two instances could be found of structural conditions being applied to the collection of data on public en- terprises. ${ }^{46}$ Bolivia was the only one of these countries to have compiled financial data on all public enterprises with a reasonable degree of specificity and reliability. In the others, even information on the direct financial flows between public enterprises and the government was frequently unavailable or incomplete, and there were no data on nonbank borrowing (some of which may have been government guaranteed). Also unrecorded were the numerous forms of indirect or noncash support that governments commonly provided to favored public enterprises, such as implicit interest subsidies, loan or exchange rate guarantees, and relief or forgiveness on tax and loan liabilities. In short, the status quo in this area looks much the same as it did at the time of the last review four years ago: public enterprise data are generally adequate in Western Hemisphere countries but still extremely poor in most African countries.

This is an issue on which the IMF should take a more proactive role, in cooperation with the World Bank, by helping to marshall donors' financial and technical resources to assist countries in what is admittedly a complex and skill-intensive task and by applying conditionality to reinforce the importance of action in this area. The authorities could be encouraged to focus initially on a few key enterprises, expanding coverage as resources permit, but should aim to record not only enterprises' direct financial transactions with government and banks but also quasi-fiscal support, such as government guarantees for domestic borrowing.

One consequence of the lack of adequate financial data on public enterprises has been that IMF staff were generally not in a position to identify promptly serious emerging financial problems in specific enterprises, and hence to advise the World Bank and the national authorities on the choice of enterprises to be targeted for urgent reform. ${ }^{47}$ Such problems were most severe in cases where the Bank was supporting reform through sectoral operations, which tended to focus on enterprises that were perceived as major bottlenecks to growth (public utilities and key export producers, for instance), rather than those that imposed the biggest financial drain on the state budget. Once equipped with the necessary information, IMF staff will need to play a more active role in such circumstances, where its central interest in the state

\footnotetext{
${ }^{46}$ The two instances were Bolivia (1988 ESAF) and Senegal (1995 ESAF). The other countries examined were Ghana, Mongolia, and Zimbabwe; see Decressin and others (forthcoming).

${ }^{47}$ In Ghana, earlier recognition of financial weaknesses in the state petroleum company (GNPC) might have brought this enterprise into the reform program before it put at risk the stabilization objectives of the IMF staff-monitored and ESAF-supported programs of the early 1990s.
} 
finances and monetary conditions in the economy as a whole is at stake. In particular, programs should seek to monitor financial flows between public enterprises, the state budget, and the banking system more comprehensively, so that budget constraints can be hardened.

More generally, conditionality in ESAF-supported programs should continue to reinforce public enterprise reforms planned under the aegis of the World Bank. Particular attention could be paid to measures that promote competition, such as liberalizing the codes governing domestic and foreign direct investment and removing monopoly rights, since these help not only to exert some market discipline over public enterprises but also to create the right environment for privatization.

\section{Restructuring Banking Systems}

One manifestation of the inefficiencies and financial mismanagement in the public enterprise sector was a substantial accumulation of nonperforming loans in the banking systems of ESAF countries, often amounting to one-third or more of banks' total portfolios. This problem was related to, and compounded by, structural weaknesses in the banks' own management, many of which stemmed from too much government intervention in lending decisions and insufficient effective prudential regulation and supervision.

The five case studies examined suggest several reasons why progress in restructuring and reforming banking systems in ESAF countries has continued to falter. ${ }^{48}$ Lack of political commitment-especially an unwillingness to cede political influence over banks' operations - was an important factor in countries in which progress has been particularly poor. A scarcity of banking expertise and skilled staff has also been a problem, one that can be remedied only with time, and a continuation of extensive technical assistance from the IMF and other institutions. On three counts, however, the IMF could take more direct action to improve performance in future ESAFsupported programs.

First, the huge fiscal costs held back reform in some instances (Tanzania provides a clear example). This appeared to result from a failure to articulate the complete strategy at the outset, which would have allowed costs to be better anticipated and financing identified. 49 There is scope for IMF staff to

\footnotetext{
${ }^{48}$ The five countries examined in this part of the study were Bolivia, Ghana, the Lao People's Democratic Republic, Senegal, and Tanzania.

${ }^{49} \mathrm{By}$ contrast, the comparative success of banking reforms in Ghana and Senegal appears to owe much to their comprehensive initial planning.
}

engage more actively in discussions with the World Bank and national authorities at the planning stage to ensure that all potential fiscal costs are assessed, including some that tend to be overlooked, such as running costs for loan recovery agencies. As well as reducing the likelihood that reforms would run into financial roadblocks once under way, more prior attention to these issues would have the important advantage of concentrating minds on the link between the pace of a planned strategy and its costs, and might in some cases lead to the adoption of a more ambitious (hence, typically, cheaper) approach than would otherwise have been selected. It could also help to ensure greater emphasis on design featuressuch as an appropriate "exit" (bank closure) strategy - that would serve simultaneously to promote substantive reform and save budgetary resources. In this regard, consideration could be given to sharing the costs of restructuring more broadly among shareholders, creditors, and depositors-among other things, to reduce risks of moral hazard.

Second, piecemeal implementation weakened the impact of reforms, leading in some cases to significant delays and even reversals. Proceeding, for instance, with financial restructuring (to tackle the "stock" problem) without reforming banks' operations or enforcing the new prudential and regulatory environment (the "flow" problem) tended to result in recurring bank distress. ${ }^{50}$ Similarly, failure to upgrade the legal and judicial framework, to allow effective enforcement of contracts, resulted in low loan-recovery rates (as in Senegal and Tanzania), adding to the net cost and thereby hampering reform. The IMF could contribute to more comprehensive implementation by refocusing its conditionality in ESAF-supported programs. The case studies suggest that past use of structural performance criteria and benchmarks has not been very effective, at least in part because of its emphasis on approving plans and passing laws rather than on operational achievements. Instead, programs should monitor the adequacy of policies affecting the banking system and the ability of the authorities to enforce best practices. ${ }^{51}$ Key aspects would include licensing and exit policies, lender-of-last-resort facilities, rules for loan classification and provisioning, capital standards, and the legal authority and capacity of supervisors to implement prudential regulations and impose penalties. Performance in these areas as well as in relation to the broader and longer-term goals of banking reform should be assessed in the context of program reviews.

\footnotetext{
${ }^{50}$ This occurred in Bolivia, the Lao People's Democratic Republic, and, to some extent, in Tanzania.

${ }^{51}$ Best practices could be drawn from Basle Committee's Core Principles for Effective Supervision; see Basle Committee on Banking Supervision (1997).
} 
Third, lack of progress in public enterprise reform undermined bank restructuring efforts. Indeed, the problem of weak loan portfolios is unlikely to be solved on a lasting basis until the financial weaknesses in the public enterprise sector are satisfactorily addressed. If, as proposed above, information is compiled on the balance sheets and financial transactions of public enterprises, the interrelationships would become clearer, and this may help to promote more concerted strategies for the public enterprise and banking sectors.

\section{Sustaining Programs}

The preceding sections have examined the policies and outcomes in all ESAF countries and identified specific areas where the design of programs could be improved. This final section approaches program design from a different perspective - that of countries in which significant interruptions occurred in or between SAF/ESAF-supported programs. The concern in such cases goes beyond a desire solely to avoid breaks in IMF arrangements: if deviations from planned policies were sufficiently large to cause the IMF to withhold support, they could also have been harmful to investors' and market sentiment, and hence to economic performance. The resulting loss of credibility is costly even when policy adjustments are subsequently made to retrieve the ground lost during the interruption. In the analysis of this issue presented in Mecagni (forthcoming), two principal questions were posed: What were the main factors that gave rise to the interruptions? And could programs have been designed or monitored differently to reduce the frequency of interruptions without unduly compromising objectives?

To the extent that changes in design or monitoring could not be expected to eliminate interruptions, an important-and considerably more difficult—question is raised: would greater selectivity in approving arrangements help? This question is posed not so much from the perspective of whether it would limit the use of IMF resources in risky situations; rather, the issue considered is whether greater selectivity would encourage countries to commit themselves more forcefully to appropriate policies. While it is not possible to address this question empirically (the construction of a counterfactual would be too subjective to be useful), the concluding paragraph raises some considerations that bear on the question.

In this study, interruptions refer to delays of longer than six months between (1) a scheduled review and its actual completion, (2) two annual arrangements in a three-year arrangement, or (3) two three-year arrangements. Like any definition of interruptions, this one has an element of arbitrariness. However, upon examination it appeared to capture situations where a clear lapse from the desired pace of adjustment occurred. By this definition, program interruptions have been numerous. Fifty-one significant interruptions of SAF- or ESAF-supported programs have occurred since the inception of the SAF in 1986, affecting 28 of the 36 countries under review. Only onefourth of all three- or four-year arrangements were completed without significant interruption. ${ }^{52}$ The high frequency of interruptions was a critical motivation for examining separately these particular experiences during SAF/ESAF-supported programs.

There is a temptation to think of interruptions as the result only of severe policy slippages. In fact, in almost one-third of the 51 episodes examined, the primary cause of the interruption was not the need to correct a significant policy slippage. About one-sixth of all interruptions stemmed from severe political upheavals that called into question the authority of the government to negotiate or provide a credible commitment to a program. In most of these cases, past policy slippages had occurred, but even in these the dominant factor underlying the interruption and its length was the need to resolve a political crisis before concerted attention could be given to the economic program. In another one-sixth of interruptions, past policies had been broadly satisfactory, but there were delays in agreeing on future policies. In most of these episodes, time was needed for the authorities to muster political support for certain measures or for the IMF and the authorities to agree on measures to address the effects of a recent unexpected external shock.

Thus, about two-thirds of the interruptions were strongly affected by serious slippages in past policies that either weakened the government's credibility or produced protracted disagreements between the IMF and the government on remedial measures. Not surprisingly, the evidence suggests that, on average, these interruptions were associated with significantly worse policies than uninterrupted programs (Figure 23 shows the comparative evidence for fiscal policies: the interrupted programs-those in black - clearly tend to fall in the left, or "worse," half of the distribution of fiscal outturns).

An examination of the interruptions attributable to policy slippages finds little support for the view that changes in program design could have made a significant difference to the occurrence or length of the interruption. Still, specific modifications are identified that might have helped in a handful of past episodes and that are worth considering for the fu-

\footnotetext{
${ }^{52}$ Excluded from these calculations were SAF arrangements that were replaced before completion with ESAF arrangements, arrangements that had an original duration of less than three years, and three-year arrangements that have not yet run their course.
} 


\section{Figure 23. Frequency Distribution of Changes in the Fiscal Balancel}

(In percent of GDP, excluding grants)

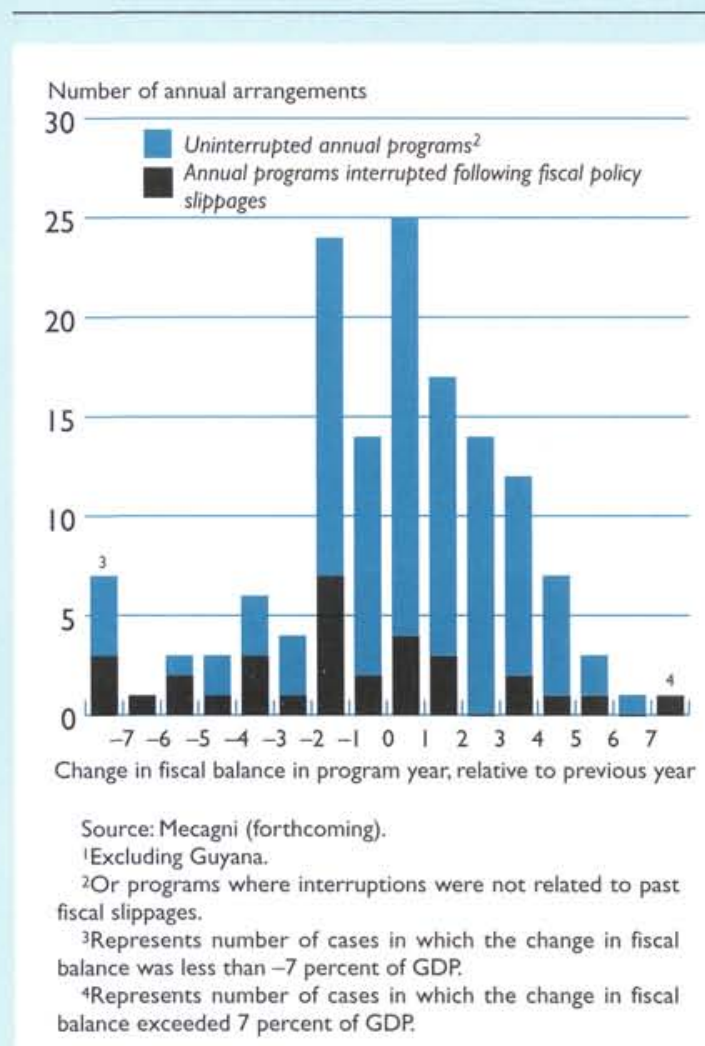

ture. These conclusions were reached by examining five possible weaknesses in program design that might have contributed to interruptions:

- Targets for macroeconomic policies were too ambitious.

- The program of structural reform was insufficiently prioritized.

- The provision of technical assistance was inadequate.

- IMF staff monitoring and consultation with authorities was too infrequent.

- Contingency planning was inadequate.

Identifying overambitiousness in financial targets is far from straightforward. What is achievable in one country at one time may not be a relevant benchmark for other countries with different capacities and constraints or even for the same country at another time. Still, a comparison of targets for key macroeconomic policy variables-such as the main fiscal aggregates-in interrupted annual arrangements with the average of those for all annual arrangements provides a crude test of the hypothesis that interrupted programs were overly ambitious. By this standard, most of the annual targets for the programs interrupted due to policy slippages were not more ambitious than the "average" program, and the average targeted change adjusted for initial conditions in these interruption cases was not statistically different from that for all programs (Figure 24). ${ }^{53}$

Another approach to the overambitiousness hypothesis is to consider what the targets for interrupted programs would have been had the outcomes reflecting policy slippages been the original targets. This possibility was considered for the 13 interrupted programs where fiscal targets appeared from Figure 24 to be relatively ambitious (that is, for programs above and to the right of the regression line). In 10 of these cases, the fiscal deficit actually deteriorated, at times by several percentage points of GDP. In 7 cases, the policies implemented resulted in the accumulation of external arrears. In another 4 instances, "lowering the bar" to match the actual outcomes would have implied accepting inflation either rising or stuck in the $20-30$ percent range. In sum, it appears that easing targets to match outcomes would in most cases have implied endorsement of deteriorating macroeconomic conditions.

There is also little evidence in favor of the hypothesis that overly ambitious or insufficiently prioritized structural reforms were a key cause of interruptions. First, interruptions were linked far more frequently and directly to slippages in macroeconomic policies than to those in structural policies. While structural policies were often not implemented as expected (interruptions linked to policy slippages followed periods in which, on average, over two-thirds of structural benchmarks and about half of the structural performance criteria had been missed), only in a few instances could the proximate cause of the slippage be seen as structural in nature. Second, taking structural benchmarks and performance criteria as an indication of the prioritizing of structural reforms, programs where past policy slippages were the major influence on interruptions typically had no more such conditions than the average for all programs: programs interrupted due to policy slippages had on average two- three structural performance criteria and six- seven structural benchmarks, in line with the wider sample. ${ }^{54}$

\footnotetext{
${ }^{53}$ This result was obtained by regressing the targeted change in the fiscal balance (excluding grants) on the previous year's fiscal balance and a constant, for all annual SAF/ESAF-supported programs for which data are available (excluding some extreme outliers). A dummy variable for years in which a program was interrupted because of policy slippages was found to be statistically insignificant.

${ }^{54} \mathrm{For}$ these purposes, reflecting data availability, the wider sample was taken to be all ESAF-supported programs approved since 1991 .
} 


\section{Figure 24. Targeted Change in Fiscal Balance in Interruptions Affected by Policy Slippages 1,2 \\ (In percent of GDP, excluding grants)}

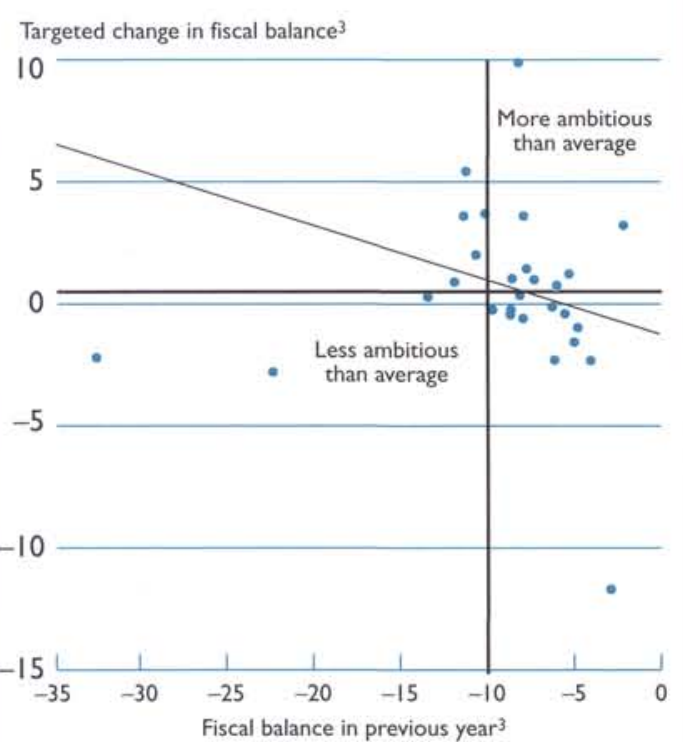

Source: Mecagni (forthcoming).

IThe horizontal and vertical lines shown correspond to the average values of the variables in the control group of annual programs not affected by interruptions.

2The regression line shows the estimated relation between targeted change in fiscal balance, initial imbalance, and a constant for the sample of all annual programs. The sample excludes seven outlier observations.

3Using the initial fiscal balance as estimated at the time the program was formulated, which in some cases differs from the final data.

Closely linked to the question of whether policy programs were overly ambitious is that of the adequacy of technical assistance. All of the countries supported through the ESAF have poor administrative capacity, and more technical assistance, if properly received and utilized, would help realize stronger adjustment. In at least four countries, however, it appears that administrative constraints were so severe as to be a key factor behind the interruption of a program - that is, the pace of reform consistent with ESAF support required greater administrative capacity than existed. In at least two of these four cases (Burkina Faso and Mozambique), efforts to provide technical assistance met with less than complete cooperation from officials. In the Lao People's Democratic Republic, despite a substantial technical assistance effort (covering fiscal, monetary, and statistical issues), the reform agenda still far exceeded implementation capacity. These cases illustrate the limits to what technical assistance can achieve in the short term, with or without the full cooperation of the authorities. However, Equatorial Guinea provides an example where, at least with the benefit of hindsight, it can be said that the IMF could have been more proactive in pressing the authorities to request and work with technical assistance teams.

Because ESAF arrangements are subject to requirements for relatively infrequent formal monitoring (by comparison with stand-by and extended arrangements), it is reasonable to ask whether more frequent monitoring could have helped forestall emerging slippages. A comparison between ESAFsupported countries and countries receiving IMF support among the Baltic countries, Russia, and other countries of the former Soviet Union is telling. The number of resident representatives, the frequency of staff visits, and the total staff resources per country have all been considerably greater in these countries than in ESAF countries. Moreover, quarterly test dates and formal quarterly (or even more frequent) review requirements have existed in all stand-by and extended arrangements with the Baltic countries, Russia, and other countries of the former Soviet Union, while ESAF arrangements have had only half-yearly test dates and reviews..$^{55}$ Although causality cannot be inferred, the much lower frequency of interruptions (5 out of 29) in arrangements with the Baltic countries, Russia, and other countries of the former Soviet Union than in SAF or ESAF arrangements (51 out of 68 ) is striking.

It is reasonable to suppose, therefore, that more intensive program monitoring - through quarterly test dates (and disbursements), more frequent reviews, and perhaps more widespread assignment of resident representatives to ESAF countries - might help in some instances to keep governments' attention focused on the requirements of adjustment policies and to prompt an early response to emerging problems. This approach could be applied flexibly, for use particularly in cases where a solid track record has not been established or where the IMF and the authorities consider that it would help sustain program implementation.

The potential importance of contingency planning depends on the extent to which unexpected developments, such as the terms of trade or weather-related

\footnotetext{
55In fact, annual ESAF arrangements have no test date or disbursement at end year, implying that during the second half of each program year there is no direct penalty for poor policy performance - a penalty applies only indirectly, through the prospect of more difficult negotiations and perhaps harsher corrective measures to secure approval of the subsequent annual arrangement.
} 
shocks, significantly influenced the slippage in policies. For the most part, other than the instances of major political upheavals referred to earlier, exogenous shocks were not important causes of interruptions. They were a contributory factor, however, in eight cases. Of these programs, even though the risk of the external disturbance had been recognized ex ante, only four had an in-built contingency mechanism. Those that did not were not necessarily flawed: the implicit assumption was that unless the program were modified by a subsequent review, the effects of any disturbance would have been offset fully by additional policy adjustment. In no case, however, did these programs anticipate how such adjustment would be brought about. In at least two of these cases-Equatorial Guinea and Guinea-remedial measures (primarily, administered price adjustments) were eventually implemented. These measures would appear to have been good candidates for inclusion in a list of contingent commitments, in the sense that they could be implemented readily and were quick acting.

In sum, none of the aspects of program design examined provides a compelling explanation of program interruptions related to policy slippages. A few changes to the design or monitoring of programs may help to improve implementation, particularly a more proactive approach to the provision and coordination of technical assistance, insisting on the demonstration of countries' cooperation before some programs are approved, and more frequent monitoring and assignment of resident representatives (although the potential benefits would need to be weighed against the costs). Greater use of contingency planning may also be desirable in some circumstances, bearing in mind the risk that it may overburden programs. But in few cases is it obvious that these kinds of modification would have been sufficient to avert or considerably shorten a program interruption.

The implication is that, in fact, most program interruptions have been the result of factors outside the IMF's control - that is, major political upheavals (of the kind described at the beginning of this section) and flagging commitment. Discontinuities or weaknesses in policy management appear to have been related in roughly a dozen cases to less severe forms of political disruption, including routine elections, transitions to multiparty political systems, and social unrest. These events typically resulted in government overspending and a general distraction of the decision-making authority. However, in more than one-third of the interruptions no unusual event of this kind occurred during the period leading up to the interruption. For most of these, myriad influences were at play in the failure to implement policies as planned: lack of public support for adjustment policies, disagreements within narrower political circles, reluctance of the authorities to confront special-interest groups, poor organization, and governance-related weaknesses.

It is these conditions that raise questions about whether greater selectivity in approving arrangements would help reduce shortfalls in meeting policy commitments that ultimately produce interruptions. Specifically, by withholding IMF support for programs until authorities have demonstrated a reasonable ability to deliver agreed policy changes, could the implementation record be strengthened? Several considerations are relevant. First, policy slippages frequently occur around elections-a time when selectivity issues are particularly sensitive. Greater selectivity would probably require stronger assurances than have been provided in the past of the authorities' ability to implement policies during election cycles. Second, past interruptions are an imperfect guide to the likelihood of future interruptions. Only about half of the countries that had interruptions had more than one. Third, staff-monitored programs were almost as likely to be followed by an interrupted arrangement, or no arrangement at all, as they were to precede a program completed without interruption. These observations suggest that while greater selectivity may help build countries' resolve to implement programs as agreed, establishing the criteria for greater selectivity would be far from straightforward. Without greater selectivity, however, interruptions are likely to remain a feature of the ESAF experience, as the IMF continues to assist members at the margins of commitment and in the midst of difficult political transitions to start the adjustment process or push ahead with reforms already begun. 


\section{Appendix. Annual Arrangements Under the SAF and ESAF}

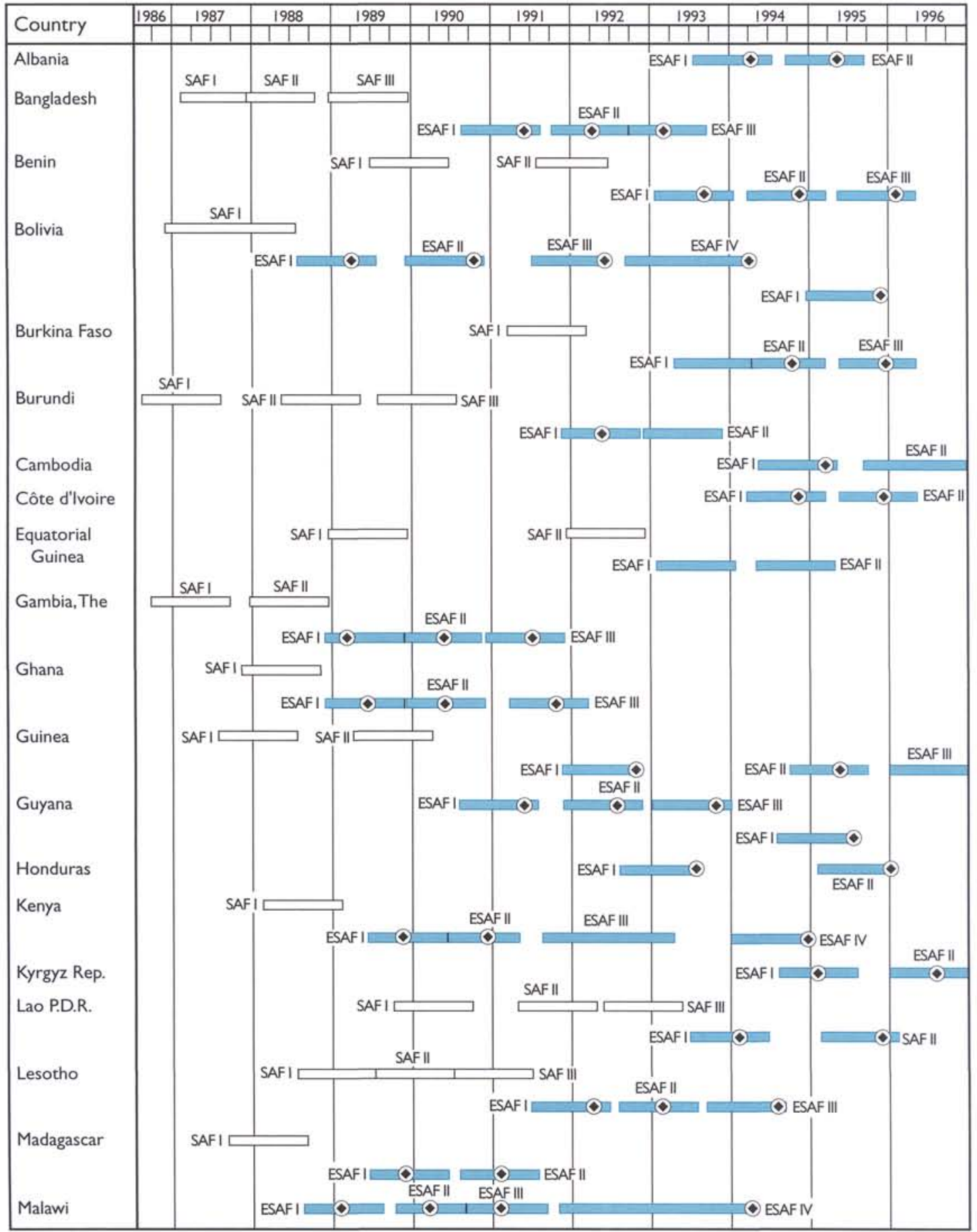




\section{Appendix (concluded)}

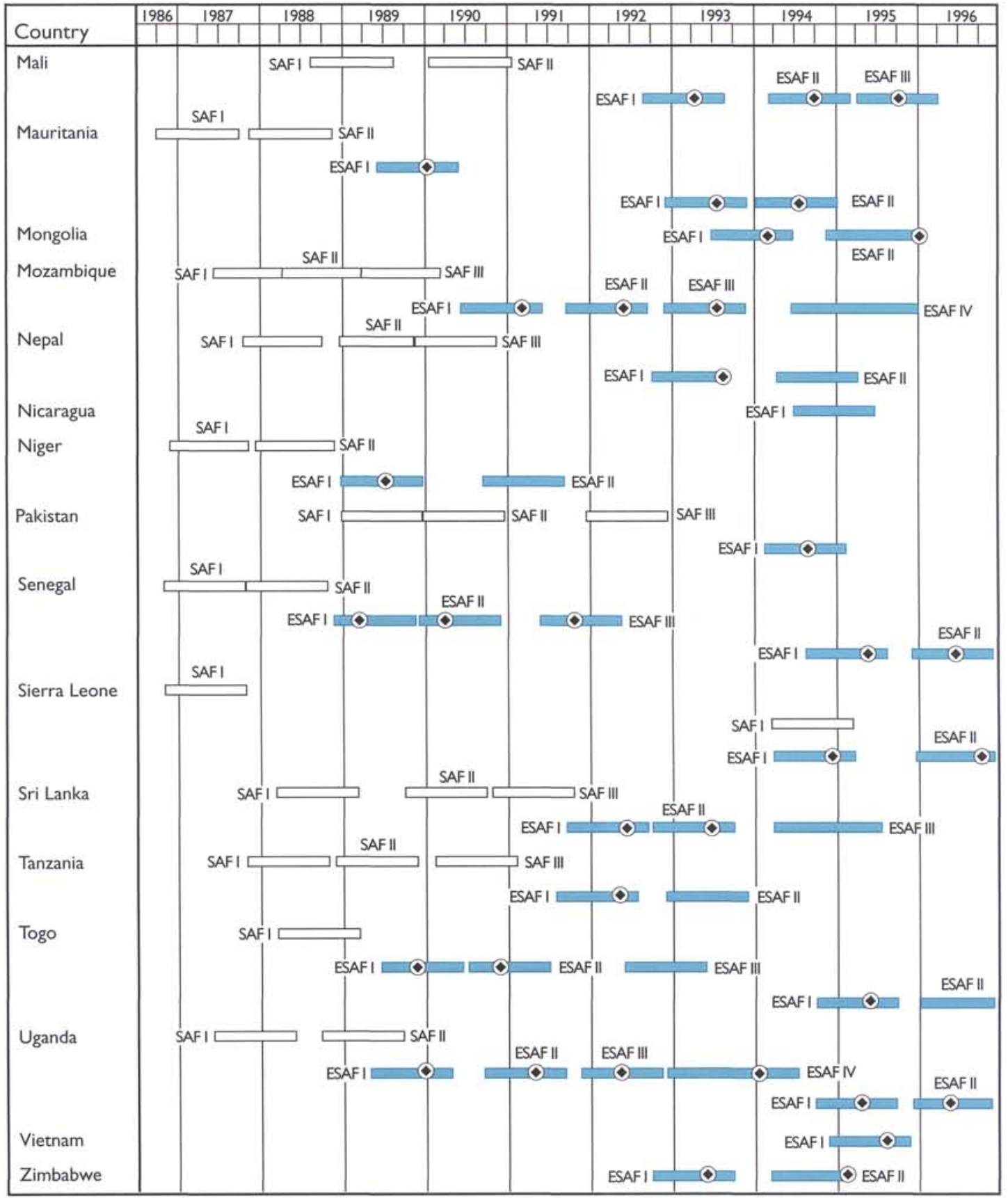

'Countries for which an ESAF arrangement was approved before December 31, 1994. The symbol in the ESAF bars indicates when a review was completed. 


\section{References}

Abed, G., and others, forthcoming, Fiscal Reforms in Low-Income Countries: Experience Under IMF-Supported Programs (Washington: International Monetary Fund).

Basle Committee on Banking Supervision, 1997, Core Principles for Effective Supervision, Consultative Paper (Basle).

Bredenkamp, H., forthcoming, "Methodological Issues," in Economic Adjustment and Reform in Low-Income Countries: Studies by the Staff of the IMF, ed. by $\mathrm{H}$. Bredenkamp and S. Schadler (Washington: International Monetary Fund).

, and S. Schadler, eds., forthcoming, Economic Adjustment Reform in Low-Income Countries: Studies by the Staff of the IMF (Washington: International Monetary Fund).

Coorey, S. and K. Kochhar, forthcoming, "Economic Growth: What Has Been Achieved and How?" in Economic Adjustment and Reform in Low-Income Countries: Studies by the Staff of the IMF, ed. by $\mathrm{H}$. Bredenkamp and S. Schadler (Washington: International Monetary Fund).

Decressin, J., L. Dicks-Mireaux, Zia Ebrahim-zadeh, and A. Ibrahim, forthcoming, "Moving Ahead with Structural Reform," in Economic Adjustment and Reform in Low-Income Countries: Studies by the Staff of the $I M F$, ed. by H. Bredenkamp and S. Schadler (Washington: International Monetary Fund).

Dicks-Mireaux, L., J. Le Dem, K. Kochhar, and S. Phillips, forthcoming, "The Policy Record," in Economic Adjustment and Reform in Low-Income Countries: Studies by the Staff of the IMF, ed. by H. Bredenkamp and S. Schadler (Washington: International Monetary Fund).

Goldsbrough, D., S. Coorey, L. Dicks-Mireaux, B. Horvath, K. Kochhar, M. Mecagni, E. Offerdal, and J. Zhou, 1996, Reinvigorating Growth in Developing Countries: Lessons from Adjustment Policies in Eight Countries, IMF Occasional Paper 139 (Washington: International Monetary Fund).
Haggard, S., J-D. Lafay, and C. Morrisson, 1995, The Political Feasibility of Adjustment in Developing Countries, Development Center Studies (Paris: Organization for Economic Cooperation and Development).

International Monetary Fund, 1996, World Economic Outlook, October 1996: A Survey by the Staff of the International Monetary Fund, World Economic and Financial Surveys (Washington).

Jayarajah, C., W. Branson, and B. Sen, 1996, Social Dimensions of Adjustment: World Bank Experience, 1980-93 (Washington: World Bank).

Mecagni, M., forthcoming, "The Causes of Program Interruptions," in Economic Adjustment and Reform in Low-Income Countries: Studies by the Staff of the $I M F$, ed. by $\mathrm{H}$. Bredenkamp and S. Schadler (Washington: International Monetary Fund).

Phillips, S., forthcoming, "Inflation: The Case for a More Resolute Approach," in Economic Adjustment and Reform in Low-Income Countries: Studies by Staff of the $I M F$, ed. by $\mathrm{H}$. Bredenkamp and S. Schadler (Washington: International Monetary Fund).

Schadler, S., F. Rozwadowski, S. Tiwari, and D. Robinson, 1993, Economic Adjustment in Low-Income Countries: Experience Under the Enhanced Structural Adjustment Facility, IMF Occasional Paper 106 (Washington: International Monetary Fund).

Schadler, S., A. Bennett, M. Carkovic, L. Dicks-Mireaux, M. Mecagni, J. Morsink, and M. Savastano, 1995a, IMF Conditionality: Experience Under Stand-By and Extended Arrangements-Part I, IMF Occasional Paper 128 (Washington: International Monetary Fund). 1995b, IMF Conditionality: Experience Under Stand-By and Extended Arrangements-Part II, IMF Occasional Paper 129 (Washington: International Monetary Fund).

Tsikata, T., forthcoming, "Progress Toward External Viability," in Economic Adjustment and Reform in LowIncome Countries: Studies by the Staff of the IMF, ed. by $\mathrm{H}$. Bredenkamp and S. Schadler (Washington: International Monetary Fund). 


\section{Recent Occasional Papers of the International Monetary Fund}

156. The ESAF at Ten Years: Economic Adjustment and Reform in Low-Income Countries, by the Staff of the International Monetary Fund. 1997.

155. Fiscal Policy Issues During the Transition in Russia, by Augusto Lopez-Claros and Sergei Alexashenko [forthcoming].

154. Credibility Without Rules? Monetary Frameworks in the Post-Bretton Woods Era, by Carlo Cottarelli and Curzio Giannini. 1997.

153. Pension Regimes and Saving, by G.A. Mackenzie, Philip Gerson, and Alfredo Cuevas. 1997.

152. Hong Kong, China: Growth, Structural Change, and Economic Stability During the Transition, by John Dodsworth and Dubravko Mihaljek. 1997.

151. Currency Board Arrangements: Issues and Experiences, by a staff team led by Tomás J.T. Baliño and Charles Enoch. 1997.

150. Kuwait: From Reconstruction to Accumulation for Future Generations, by Nigel Andrew Chalk, Mohamed A. El-Erian, Susan J. Fennell, Alexei P. Kireyev, and John F. Wison. 1997.

149. The Composition of Fiscal Adjustment and Growth: Lessons from Fiscal Reforms in Eight Economies, by G.A. Mackenzie, David W.H. Orsmond, and Philip R. Gerson. 1997.

148. Nigeria: Experience with Structural Adjustment, by Gary Moser, Scott Rogers, and Reinold van Til, with Robin Kibuka and Inutu Lukonga. 1997.

147. Aging Populations and Public Pension Schemes, by Sheetal K. Chand and Albert Jaeger. 1996.

146. Thailand: The Road to Sustained Growth, by Kalpana Kochhar, Louis Dicks-Mireaux, Balazs Horvath, Mauro Mecagni, Erik Offerdal, and Jianping Zhou. 1996.

145. Exchange Rate Movements and Their Impact on Trade and Investment in the APEC Region, by Takatoshi Ito, Peter Isard, Steven Symansky, and Tamim Bayoumi. 1996.

144. National Bank of Poland: The Road to Indirect Instruments, by Piero Ugolini. 1996.

143. Adjustment for Growth: The African Experience, by Michael T. Hadjimichael, Michael Nowak, Robert Sharer, and Amor Tahari. 1996.

142. Quasi-Fiscal Operations of Public Financial Institutions, by G.A. Mackenzie and Peter Stella. 1996.

141. Monetary and Exchange System Reforms in China: An Experiment in Gradualism, by Hassanali Mehran, Marc Quintyn, Tom Nordman, and Bernard Laurens. 1996.

140. Government Reform in New Zealand, by Graham C. Scott. 1996.

139. Reinvigorating Growth in Developing Countries: Lessons from Adjustment Policies in Eight Economies, by David Goldsbrough, Sharmini Coorey, Louis Dicks-Mireaux, Balazs Horvath, Kalpana Kochhar, Mauro Mecagni, Erik Offerdal, and Jianping Zhou. 1996.

138. Aftermath of the CFA Franc Devaluation, by Jean A.P. Clément, with Johannes Mueller, Stéphane Cossé, and Jean Le Dem. 1996.

137. The Lao People's Democratic Republic: Systemic Transformation and Adjustment, edited by Ichiro Otani and Chi Do Pham. 1996.

136. Jordan: Strategy for Adjustment and Growth, edited by Edouard Maciejewski and Ahsan Mansur. 1996.

135. Vietnam: Transition to a Market Economy, by John R. Dodsworth, Erich Spitäller, Michael Braulke, Keon Hyok Lee, Kenneth Miranda, Christian Mulder, Hisanobu Shishido, and Krishna Srinivasan. 1996.

134. India: Economic Reform and Growth, by Ajai Chopra, Charles Collyns, Richard Hemming, and Karen Parker with Woosik Chu and Oliver Fratzscher. 1995.

133. Policy Experiences and Issues in the Baltics, Russia, and Other Countries of the Former Soviet Union, edited by Daniel A. Citrin and Ashok K. Lahiri. 1995.

132. Financial Fragilities in Latin America: The 1980s and 1990s, by Liliana Rojas-Suárez and Steven R. Weisbrod. 1995. 
131. Capital Account Convertibility: Review of Experience and Implications for IMF Policies, by staff teams headed by Peter J. Quirk and Owen Evans. 1995.

130. Challenges to the Swedish Welfare State, by Desmond Lachman, Adam Bennett, John H. Green, Robert Hagemann, and Ramana Ramaswamy. 1995.

129. IMF Conditionality: Experience Under Stand-By and Extended Arrangements. Part II: Background Papers. Susan Schadler, Editor, with Adam Bennett, Maria Carkovic, Louis Dicks-Mireaux, Mauro Mecagni, James H.J. Morsink, and Miguel A. Savastano. 1995.

128. IMF Conditionality: Experience Under Stand-By and Extended Arrangements. Part I: Key Issues and Findings, by Susan Schadler, Adam Bennett, Maria Carkovic, Louis Dicks-Mireaux, Mauro Mecagni, James H.J. Morsink, and Miguel A. Savastano. 1995.

127. Road Maps of the Transition: The Baltics, the Czech Republic, Hungary, and Russia, by Biswajit Banerjee, Vincent Koen, Thomas Krueger, Mark S. Lutz, Michael Marrese, and Tapio O. Saavalainen. 1995.

126. The Adoption of Indirect Instruments of Monetary Policy, by a staff team headed by William E. Alexander, Tomás J.T. Baliño, and Charles Enoch. 1995.

125. United Germany: The First Five Years-Performance and Policy Issues, by Robert Corker, Robert A. Feldman, Karl Habermeier, Hari Vittas, and Tessa van der Willigen. 1995.

124. Saving Behavior and the Asset Price "Bubble" in Japan: Analytical Studies, edited by Ulrich Baumgartner and Guy Meredith. 1995.

123. Comprehensive Tax Reform: The Colombian Experience, edited by Parthasarathi Shome. 1995.

122. Capital Flows in the APEC Region, edited by Mohsin S. Khan and Carmen M. Reinhart. 1995.

121. Uganda: Adjustment with Growth, 1987-94, by Robert L. Sharer, Hema R. De Zoysa, and Calvin A. McDonald. 1995.

120. Economic Dislocation and Recovery in Lebanon, by Sena Eken, Paul Cashin, S. Nuri Erbas, Jose Martelino, and Adnan Mazarei. 1995.

119. Singapore: A Case Study in Rapid Development, edited by Kenneth Bercuson with a staff team comprising Robert G. Carling, Aasim M. Husain, Thomas Rumbaugh, and Rachel van Elkan. 1995.

118. Sub-Saharan Africa: Growth, Savings, and Investment, by Michael T. Hadjimichael, Dhaneshwar Ghura, Martin Mühleisen, Roger Nord, and E. Murat Uçer. 1995.

117. Resilience and Growth Through Sustained Adjustment: The Moroccan Experience, by Saleh M. Nsouli, Sena Eken, Klaus Enders, Van-Can Thai, Jörg Decressin, and Filippo Cartiglia, with Janet Bungay. 1995 .

116. Improving the International Monetary System: Constraints and Possibilities, by Michael Mussa, Morris Goldstein, Peter B. Clark, Donald J. Mathieson, and Tamim Bayoumi. 1994.

115. Exchange Rates and Economic Fundamentals: A Framework for Analysis, by Peter B. Clark, Leonardo Bartolini, Tamim Bayoumi, and Steven Symansky. 1994.

114. Economic Reform in China: A New Phase, by Wanda Tseng, Hoe Ee Khor, Kalpana Kochhar, Dubravko Mihaljek, and David Burton. 1994.

113. Poland: The Path to a Market Economy, by Liam P. Ebrill, Ajai Chopra, Charalambos Christofides, Paul Mylonas, Inci Otker, and Gerd Schwartz. 1994.

112. The Behavior of Non-Oil Commodity Prices, by Eduardo Borensztein, Mohsin S. Khan, Carmen M. Reinhart, and Peter Wickham. 1994.

111. The Russian Federation in Transition: External Developments, by Benedicte Vibe Christensen. 1994.

110. Limiting Central Bank Credit to the Government: Theory and Practice, by Carlo Cottarelli. 1993.

109. The Path to Convertibility and Growth: The Tunisian Experience, by Saleh M. Nsouli, Sena Eken, Paul Duran, Gerwin Bell, and Zühtü Yücelik. 1993.

Note: For information on the title and availability of Occasional Papers not listed, please consult the IMF Publications Catalog or contact IMF Publication Services. 